World Maritime University

The Maritime Commons: Digital Repository of the World Maritime University

$9-17-2019$

\title{
Third WMU International Women's Conference : Empowering Women in the Maritime Community
}

World Maritime University

Follow this and additional works at: https://commons.wmu.se/lib_reports

\section{Recommended Citation}

World Maritime University, "Third WMU International Women's Conference : Empowering Women in the Maritime Community" (2019). Reports. 62.

https://commons.wmu.se/lib_reports/62

This Open Access Report is brought to you courtesy of Maritime Commons. Open Access items may be downloaded for non-commercial, fair use academic purposes. No items may be hosted on another server or web site without express written permission from the World Maritime University. For more information, please contact library@wmu.se. 


\section{WWes:m}

Published by

World Maritime University

DOI: http://dx.doi.org/10.21677/cr.20190828

ISBN Print: 978-91-985700-0-7

ISBN Online: 978-91-985700-1-4

\section{(c) 2019, World Maritime University, All rights reserved}

Nothing herein shall constitute or be considered to be a limitation upon or waiver of the privileges and immunities of the World Maritime University, in accordance with its Charter and provided for in the Convention of Privileges and Immunities of the Specialized Agencies of the United Nations of 21 November 1947, including Annex XII, as amended.

This report is copyrighted under Universal Copyright Convention. Information and short excerpts from this report may be reproduced without consent, with the exception of images whose copyright is identified, on the condition that the complete reference of the publication is given. An application should be made to World Maritime University, PO Box 500, SE 20124 Malmö, Sweden, or by email: conferences@wmu.se, for additional rights.

This report, as well as any data and any map included herein, are without prejudice to the status of or sovereignty over any territory, to the delimitation of international frontiers and boundaries and to the name of any territory, city or area. The responsibility for opinions expressed rests solely with the respective author/speaker. Any reference to organizations, companies or individuals does not imply their endorsement by the World Maritime University.

No representation or warranty is provided as to the accuracy or completeness of the information and data contained in this report. Such information and data are considered current as of the date of this report; however, there is no obligation or intention to update the information and data at any time after the date of this report. This report may contain information or data obtained from third parties, and while it is believed that any third party information or data is accurate, all such third party information or data has not necessarily been independently verified. 


\section{FOREWORD}

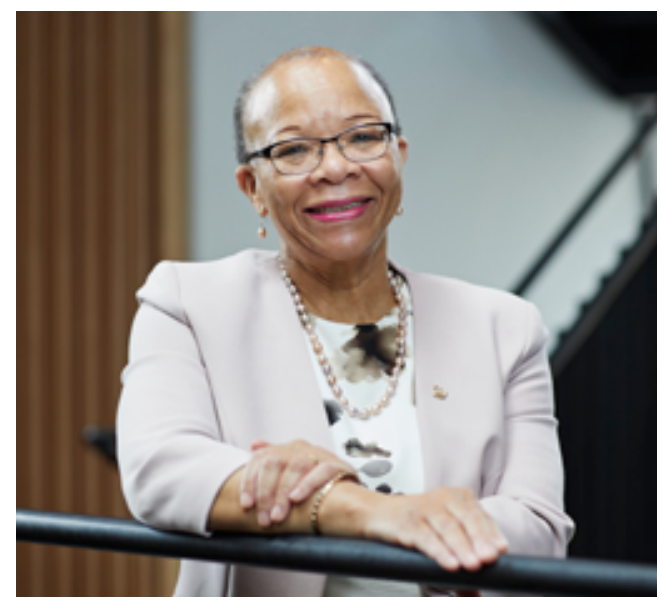

Dr. Cleopatra Doumbia-Henry

President, World Maritime University

Maritime transport and ocean-related industries are the cornerstone of national and global economies, and play a key role in ensuring development for all. Indeed, maritime and ocean industries are vital. Over 80 per cent of international trade is seaborne, and 16 per cent of world animal protein consumption by humans comes from fish. Despite the significance of maritime and ocean industries, women's contribution to these industries is often invisible. The 2015 World Maritime University (WMU) publication, entitled "Maritime Women: Global Leadership", estimates that women's representation is between 3 and 30 per cent in various maritime organizations. This includes the merchant marine, the cruise line sector and the on-shore maritime cluster. 
According to the Food and Agriculture Organization (FAO) of the United Nations, 47 per cent of the 120 million people who earn money directly from fishing and processing are women, while women make up some 70 per cent of those engaged in aquaculture. Nevertheless, gender stereotypes and discrimination against maritime women persist. They affect working conditions, equal access to education and training and career opportunities. Gender specific data is scarce. Issues such as women's health attracts scant attention and good practices regarding the empowerment of women are barely visible.

Through the power of education, the WMU has demonstrated the possibility of making changes in a short period of time. Until the late 1990s, female students made up less than 5 per cent of the Malmö intake. A recruitment strategy with strong support from fellowship donors has resulted in the proportion of female students increasing to roughly a third of the annual intake in Malmö, and our MSc in International Transport and Logistics (ITL) Class of 2019 in Shanghai achieved gender parity with 50 per cent female students. Since I joined WMU, we had a record number of 48 women enrolled in our Malmö-based MSc programme, reaching 37 per cent for the 2016-2017 student intake. Since the establishment of WMU in 1983, out of the total 4,919 graduates, 1,029 have been women, i.e., 20 per cent.

Women are enrolled across all of our MSc in Maritime Affairs specializations, including Maritime Education and Training; Maritime Energy Management; Maritime Law and Policy; Maritime Safety and Environmental Administration; Ocean Sustainability, Governance and Management; Port Management; and Shipping Management and Logistics. In addition to the strong enrolment of women in our MSc programme in Shanghai, several women are enrolled in our Maritime Safety and Environmental Management programme in Dalian, China, and many more are participating in our distance learning programmes on Marine Energy; Marine Insurance; International Maritime Law; Executive Maritime Management; and Maritime Safety and Security; as well as our LLM in International
Maritime Law. These distance-learning programmes enable those who are unable to join the academic programme in Malmö to attain quality maritime education at an affordable cost and with the flexibility that distance learning provides.

Despite the persistence of gender inequality, female champions, role models and success stories exist in every sector of the maritime and ocean communities. The Third International Women's Conference on Empowering Women in the Maritime Community, held in Malmö from 4-5 April 2019, brought together women from all of these sectors and provided a platform for discussion. The theme was adopted from the International Maritime Organization (IMO)'s 2019 World Maritime Day theme - Empowering Women in the Maritime Community. Established by the IMO in 1983, WMU supports this important initiative and has expanded it to include ocean communities.

The Conference covered four maritime and ocean themes, namely shipping ports - ocean and marine science - fishing and seafood harvesting. It was a unique opportunity to share best practices and strategies toward achieving gender equality from a wide range of perspectives. The Conference therefore took a holistic approach, abandoning silos and breaking barriers across different sectors, while opening the door to innovation.

The aim of the Conference was to identify opportunities that would encourage women to pursue maritime careers. It was also a call to action from maritime and other stakeholders in support of achieving the United Nations Sustainable Development Goals (SDGs), in particular Goal 5 related to gender equality, which is a cross-cutting theme.

The aim of the two-day Conference, which brought together over 350 participants from more than 70 countries around the world, was to address the gender gap in the maritime, oceans, ports, fishing and related industries. The Conference held 15 sessions, including three plenaries, five thematic and 
four research sessions with a total of 62 speakers. The WMU would like to thank the eight outstanding sponsors (acknowledged on page 64) who, through their generous support, contributed to the success of the Conference. These sponsors represent various sectors, including the United Nations specialized agencies, governments, shipowners, labour unions and other longterm WMU supporters.

The Conference has produced four tangible outcomes. The first and immediate outcome was the conference conclusions adopted by all the participants at the close of the Conference. The final conclusions are available at the WMU website and at the end of this Conference Report. The conclusions urge all stakeholders to take up at least one action among the 17 recommendations from the conference.

The second deliverable was the preparation and presentation of the IMO document (TC $69 / 10 / 2$ ) that was submitted to the 69th session of the IMO Technical Cooperation Committee (TC) in June 2019: "CapacityBuilding: Strengthening the Impact of Women in the Maritime Sector". The document was noted and supported by TC 69. The third deliverable was a scientific outcome of the conference that was based on a call for papers. The conference attracted 45 abstracts from both female and male authors from 23 countries. Selected peerreviewed academic papers will be published by the end of 2019 in the WMU Journal of Maritime Affairs, Special Issue, entitled "Empowering Women in the Maritime Community."

The Conference Report is the fourth deliverable. The two-day conference offered a full spectrum of gender reflections on various maritime and ocean issues. Each session provided critical takeaways and policy relevant highlights, which should be made visible and accessible. It is the expectation that this report will reach stakeholders beyond the Conference participants in order to ensure that the Conference conclusions and commitments promote positive change in support of gender equality in the maritime and ocean communities.
It is our hope that this report will add value to ongoing discussions and initiatives aimed at promoting gender equality across the maritime and ocean communities. The conclusions of the Conference are also intended to provide impetus for a new, solid beginning in order to achieve SDG 5 with enhanced partnerships and cooperation among various stakeholders. As a higher educational institution of the IMO, we continue to support the IMO's gender programme and strategic directions by promoting and demonstrating gender parity through education, research and capacitybuilding in support of the United Nations 2030 Agenda for Sustainable Development and the related goals. 


\section{CONTENTS}

EXECUTIVE SUMMARY

OPENING SESSION - KEYNOTE ADDRESS
8 Dr. Cleopatra Doumbia-Henry, President, World Maritime University

Mr. Kitack Lim, Secretary-General, International Maritime Organization

Ms. Grete Faremo, United Nations Under-Secretary-General and UNOPS Executive Director

Ms. Quah Ley Hoon, Chief Executive, Maritime and Port Authority of Singapore (MPA)

Ms. Alette van Leur, Director of the Sectoral Policies Department, International Labour Organization

Dr. Geneviève Béchard, Hydrographer General of Canada and Director General for the Canadian Hydrographic Service with Fisheries and Oceans Canada

Moderated by Dr. Jens-Uwe Schröder-Hinrichs, Vice President (Academic Affairs) of WMU

\begin{tabular}{|c|c|c|}
\hline PLENARY SESSIONS & 14 & \\
\hline $\begin{array}{r}\text { PLENARY 1: } \\
\text { WOMEN IN MARITIME LEADERSHIP }\end{array}$ & 15 & $\begin{array}{l}\text { Ms. Heike Deggim, Director, Maritime Safety Division, IMO } \\
\text { Ms. Magda Kopczynska, DG MOVE, European Commission (EC) } \\
\text { Ms. Katarina Norén, Director General, Swedish Maritime Administration } \\
\text { Ms. Maphefo Anno-Frempong, CEO, Transport Education Training Authority, } \\
\text { South Africa } \\
\text { Moderated by Dr. Maximo Q. Mejia Jr., Professor, WMU }\end{array}$ \\
\hline $\begin{array}{r}\text { PLENARY 2: } \\
\text { WOMEN'S ROLE IN INFLUENCING } \\
\text { OCEAN GOVERNANCE }\end{array}$ & 18 & $\begin{array}{l}\text { Ms. Gabriele Goettsche-Wanli, Director, United Nations Division of Ocean } \\
\text { Affairs and the Law of the Sea (DOALOS) } \\
\text { Dr. Anne Christine Brusendorff, General Secretary, International Council } \\
\text { for the Exploration of the Sea } \\
\text { Ms. Julie Gascon, Director General of Operations, Canadian Coast Guard } \\
\text { Moderated by Dr. Ronán Long, Director, WMU-Sasakawa Global Ocean } \\
\text { Institute of WMU }\end{array}$ \\
\hline $\begin{array}{r}\text { PLENARY 3: } \\
\text { ENABLING SDG 5TOWARD } \\
\text { SUSTAINABLE MARITIME } \\
\text { INDUSTRIES }\end{array}$ & 22 & $\begin{array}{l}\text { Ms. Sindisiwe Chikunga, Deputy Minister of Transport, } \\
\text { Government of South Africa } \\
\text { Ms. Birgit Sølling Olsen, Former Deputy Director-General, } \\
\text { Danish Maritime Authority } \\
\text { Ms. Margareta Jensen Dickson, Head of People, Stena Line } \\
\text { Ms. Despina Panayiotou Theodosiou, President, Women's International Ship- } \\
\text { ping and Trading Association (WISTA) } \\
\text { Moderated by Ms. Lena Dyring, Director of Cruise Operations, } \\
\text { Norwegian Seafarers' Union }\end{array}$ \\
\hline
\end{tabular}

\section{PANEL SESSIONS 26}

PANEL A: WOMEN IN SHIPPING 27 Ms. Jacqueline Smith, Maritime Coordinator, ITF

Ms. Maja Markovčić Kostelac, Executive Director, EMSA

Ms. Nancy Wakarima Karigithu, Principal Secretary, Ministry of Transport, Infrastructure, Housing \& Urban Development and Public Works, Kenya

Captain Kate McCue, Celebrity Cruises

Moderated by Ms. Natalie Shaw, Director, Employment Affairs, International Chamber of Shipping (ICS)

PANEL B: WOMEN IN PORTS 31 Ms. Mwanaulu Issa Mwajita, Senior Business Analyst (Project Manager, Maritime Single Window), Kenya Trade Network Agency

Ms. Tessa Major, the Commercial Director of Porto do Açu, Brazil

Ms. Hadiza Bala Usman, Managing Director, Nigerian Ports Authority

Moderated by Ms. Barbara Scheel Agersnap, CEO, Copenhagen Malmö Port

PANEL C: WOMEN IN OCEAN AND MARINE SCIENCE
34 Ms. Lisa Emelia Svensson, Marine and Coastal Ecosystems Branch, UN Environment Programme (UNEP)

Dr. Irini Papanicolopulu, Associate Professor of International Law, Università di Milano-Bicocca

Ms. Linda Wallin, Senior Analyst, Swedish Agency for Marine and Water Management (SwAM)

Moderated by Ms. Helen Ågren, Swedish Ambassador for the Ocean, Government of Sweden 
PANEL D: WOMEN IN FISHING

AND SEAFOOD HARVESTING

PANEL E: PARTNERSHIPS

AND NETWORKING FOR GENDER EQUALITY
38 Ms. Luz Baz Abella, ITF inspector, Vigo Spain

Mrs. Emma C. Glassco, Director General of the National fisheries and Aquaculture Authority, Liberia

Ms. Aaju Peter, Lawyer, Translator \& Inuit Cultural Advocate, Canada, Greenlandic lqaluit, Nunavut

41 Ms. Sanjam Sahi Gupta, Executive Board Member of WMU; Director, Sitara Shipping Ltd.; President of WISTA India

Capt. Patrik Dahlgren, Senior Vice President, Royal Caribbean Cruises Ltd.

Dr. Kaoru Kubokawa, Professor, University of Tokyo; Founder, Women for One Ocean

Ms. Ore O. Toua, Maritime Training Adviser, SPC; GHG Officer, MTCC Pacific

Dr. Milena Arias Schreiber, Too Big to Ignore Network; University of Gothenburg - School of Global Studies

Ms. Siti Noraishah Azizan, General Manager, Sabah Ports Sdn. Bhd.; Chair, Women's Forum in the International Association of Ports \& Harbors (IAPH)

Ms. Ally Cedeno, Founder and President, Women Offshore Foundation

Moderated by Ms. Deniece M. Aiken, Vice President, Legal \& International Affairs / Executive Director, Maritime Training Centre, Caribbean Maritime University

\begin{tabular}{|c|c|c|}
\hline RESEARCH SESSIONS & 46 & \\
\hline RESEARCH PRESENTATION-1: & 46 & $\begin{array}{l}\text { INCREASING THE VISIBILITY OF WOMEN OFTHE SEA } \\
\text { Session chair: Dr. Irini Papanicolopulu, Associate Professor of } \\
\text { International Law, Università di Milano-Bicocca }\end{array}$ \\
\hline RESEARCH PRESENTATION-2: & 48 & $\begin{array}{l}\text { MARITIME SAFETY AND SECURITY FROM GENDER PERSPECTIVES } \\
\text { Session chair: Dr. Laura Carballo Piñeiro, Professor, WMU }\end{array}$ \\
\hline RESEARCH PRESENTATION-3: & 49 & $\begin{array}{l}\text { EMPOWERING WOMEN IN MARITIME BUSINESS ANDTRADE } \\
\text { Session chair: Dr. Momoko Kitada, Associate Professor, WMU }\end{array}$ \\
\hline RESEARCH PRESENTATION-4: & 50 & $\begin{array}{l}\text { CLOSING THE GENDER GAP INTHE MARITIME COMMUNITY } \\
\text { Session chair: Dr. Maximo Q. Mejia Jr., Professor, WMU }\end{array}$ \\
\hline POSTER RESEARCH PRESENTATIONS & 52 & \\
\hline OTHER EVENTS & 53 & \\
\hline $\begin{array}{l}\text { PRESENTATION ONTHE IMO } \\
\text { GENDER PROGRAMME }\end{array}$ & 53 & $\begin{array}{l}\text { Ms. Helen Buni, Principle Programme Assistant, Technical Cooperation Division, } \\
\text { IMO }\end{array}$ \\
\hline WIMAS AND WMUWA PANEL & 54 & \\
\hline LAUNCH OF RESEARCH PROJECT & 57 & $\begin{array}{l}\text { Dr. Geneviève Béchard, Hydrographer General of Canada and Director General } \\
\text { for the Canadian Hydrographic Service with Fisheries and Oceans Canada }\end{array}$ \\
\hline COCKTAIL RECEPTION & 58 & \\
\hline $\begin{array}{l}\text { CLOSING SESSION } \\
\text { AND CONCLUSIONS }\end{array}$ & 59 & $\begin{array}{l}\text { Dr. Cleopatra Doumbia-Henry, President, WMU } \\
\text { Moderated by Ms. Nancy Wakarima Karigithu, Principal Secretary, } \\
\text { Ministry of Transport, Infrastructure, Housing \& Urban Development } \\
\text { and Public Works, Kenya }\end{array}$ \\
\hline
\end{tabular}




\section{EXECUTIVE SUMMARY}

Since its founding in 1983 under the auspices of the IMO, WMU has been committed to the advancement of women. It hosted its Third International Women's Conference on the IMO's World Maritime Day 2019 theme, entitled "Empowering Women in the Maritime Community", from 4-5 April 2019'. The 2019 Conference addressed the gender gap in maritime, ports, ocean, fishing and related industries with participants from all over the world, including governments, the maritime industry, United Nations agencies, academia, research institutes, NGOs, indigenous communities, media and WMU/ International Maritime Law Institute (IMLI) alumni.

1 The two earlier conferences were held in 2008 and 2014 on the themes "Empowerment of Professional Women in the Maritime World: the WMU Contribution" and "Maritime Women: Global Leadership" respectively.

This report summarizes the most significant outcomes of the Conference by session and speaker. It contains an executive summary followed by the Opening Session, including the welcome address by WMU President Dr. Cleopatra Doumbia-Henry, and keynote addresses by IMO Secretary General Mr. Kitack Lim (video message), Ms. Grete Faremo, United Nations Under-SecretaryGeneral and the United Nations Office for Project Services (UNOPS) Executive Director, Ms. Quah Ley Hoon, Chief Executive, Maritime and Port Authority of Singapore (MPA), Ms. Alette van Leur, Director of the Sectoral Policies Department, International Labour Organization (ILO), Dr. Geneviève Béchard, Hydrographer General of Canada and Director General for the Canadian Hydrographic Service with Fisheries and Oceans Canada.

The report contains a summary of seven sessions: three plenary sessions and four thematic panel sessions:

Plenary 1: Women in Maritime Leadership

Plenary 2: Women's Role in Influencing Ocean Governance

Plenary 3: Enabling SDG 5 Toward Sustainable Maritime Industries

Panel A: Women in Shipping

Panel B: Women in Port

Panel C: Women in Ocean and Marine Science

Panel D: Women in Fishing and Seafood Harvesting

Panel E: Partnerships and Networking for Gender Equality 
These sessions were followed by four research sessions: (1) Increasing the visibility of women of the sea; (2) Maritime safety and security from gender perspectives; (3) Empowering women in maritime business and trade; and (4) Closing the gender gap in the maritime community. In addition, the Conference offered research poster presentations during the breaks.

The Conference offered additional special presentations. A presentation on the IMO Gender Programme helped to disseminate the IMO's initiatives on empowering women in the maritime sector. At the end of day 1 , a special panel was organized on IMO's regional Women in Maritime Associations (WIMAs) and WMU Women's Association (WMUWA), which provided a forum to share best practices and strategies from each regional network.
Another highlight was the launch of a major research project, entitled "Empowering Women for the United Nations Decade of Ocean Science for Sustainable

Development", funded by the Department of Fisheries and Ocean, Canada.

Finally, the cocktail reception offered a networking opportunity for the Conference participants who enjoyed live music by an outstanding pianist/vocalist, Mrs. Karen Edwards. The Conference ended with a summary of the issues discussed and the adoption of a set of conclusions containing 17 points for action. All stakeholders were urged to commit to taking forward at least one action after the Conference.

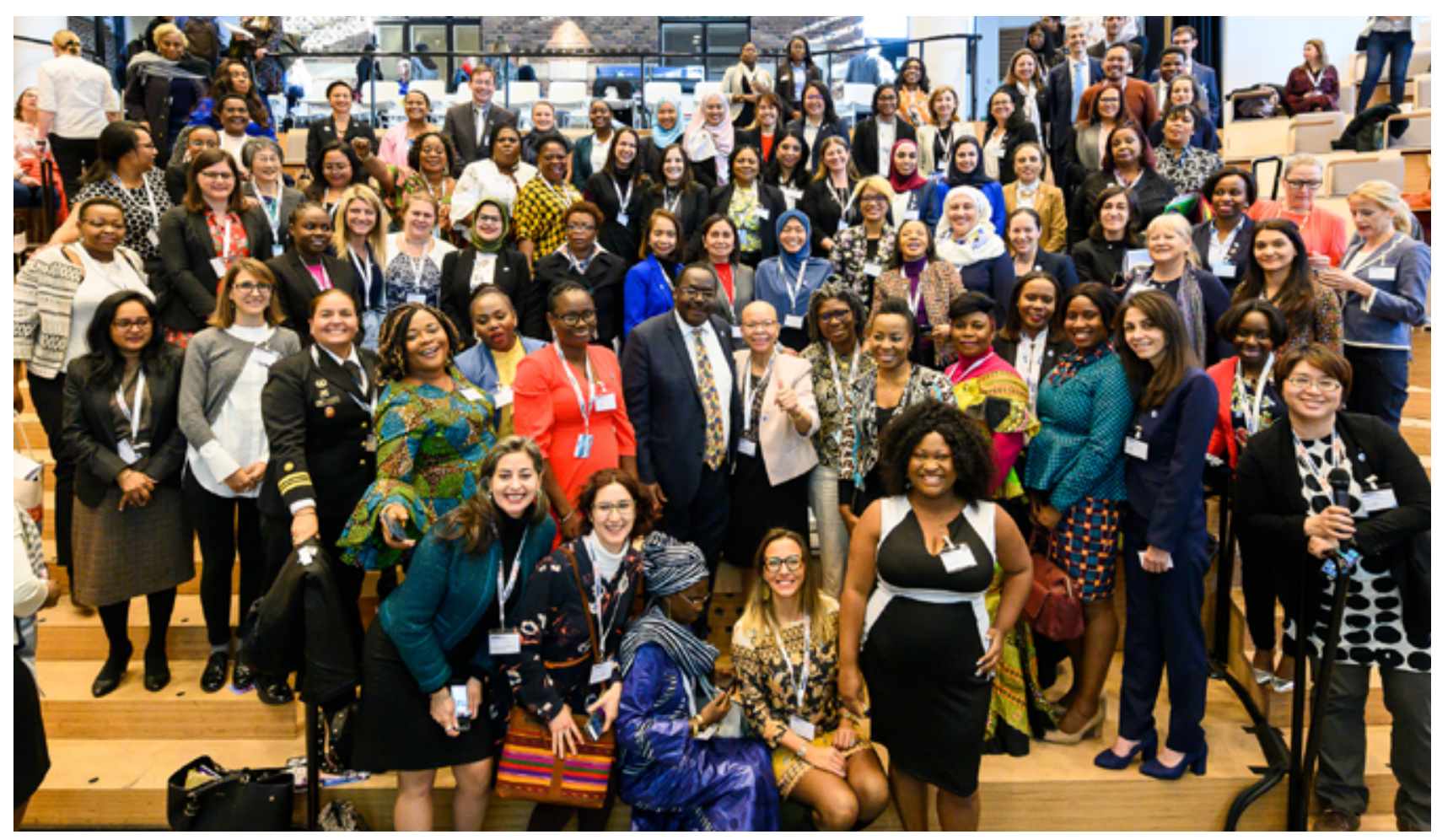




\title{
OPENING SESSION - KEYNOTE ADDRESS
}

\author{
MODERATED BY PROFESSOR JENS-UWE SCHRÖDER-HINRICHS, \\ VICE PRESIDENT (ACADEMIC), WMU
}

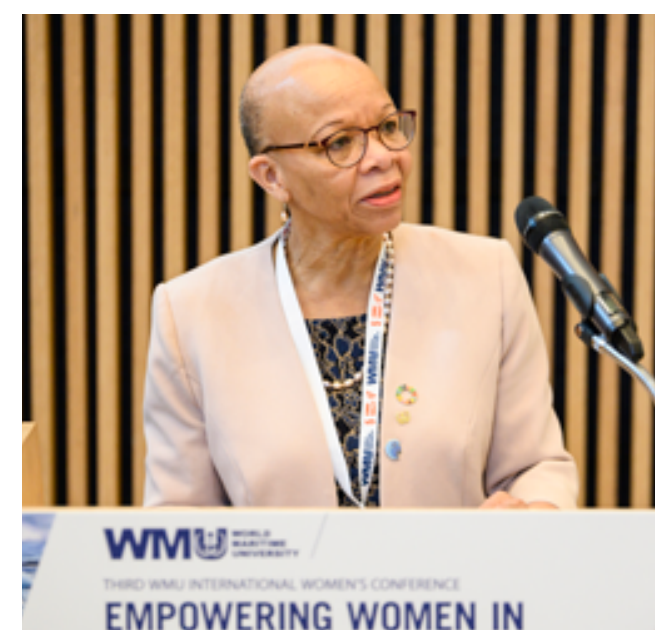

\section{"TO ENSURE READINESS FOR FUTURE MARITIME INNOVATION AND OCEAN SUSTAINABILITY, THE EMPOWERMENT OF WOMEN IN MARITIME AND OCEAN COMMUNITIES IS CRITICAL. WE AT WMU WANT TO WORK WITH ALL OF YOU TO LEAD THE CHARGE."}

DR. CLEOPATRA DOUMBIA-HENRY

\section{Dr. Cleopatra Doumbia-Henry \\ President, World Maritime University}

WMU President, Dr. Cleopatra Doumbia-Henry, welcomed over 350 participants to the conference, and said that she looked forward to the innovative ideas that would be generated and contributions made to the theme, "Empowering Women in the Maritime Community", and toward breaking the glass ceiling in the maritime and ocean sectors.

In reflecting on what had been achieved since WMU's first maritime women's conference in 2008, the WMU president noted with regret that the number of women in the maritime and ocean professions remains at unacceptably low levels. Women today represent only one to two per cent of the seafaring population, a proportion that is as low as 25 years ago. Although the last decade has seen growth in the number of women in maritime land-based activities, women are still underrepresented in the sector as a whole, making it clear that existing interventions are insufficient.

To achieve gender equity in the maritime and ocean community, and in line with the United Nations Sustainable Development Goal 5, requires "transformative shifts, integrated approaches, and new solutions." To remove existing barriers to women's participation and empowerment, Dr. Doumbia-Henry emphasized the need for innovative approaches that are disruptive and called for everyone involved in the maritime and ocean sectors today to "be bold for change."

Working toward the achievement of Goal 5, WMU, along with its partners, have been investing in women's empowerment by ensuring the incorporation of gender mainstreaming in all of its work areas and making quality education available to everyone. These continuous efforts have already shown results as female enrolment has grown from 3 per cent in 1983 to one-third in 2019. Many of WMU's women graduates have risen to prominent positions and are making significant contributions to the maritime and ocean sectors in their home countries. Dr. Doumbia-Henry invited the audience to take up the challenge to work together with WMU as advocates for the role of women to make change in order to ensure that the maritime and ocean sectors are sustainable and that no girl or woman is left behind. 


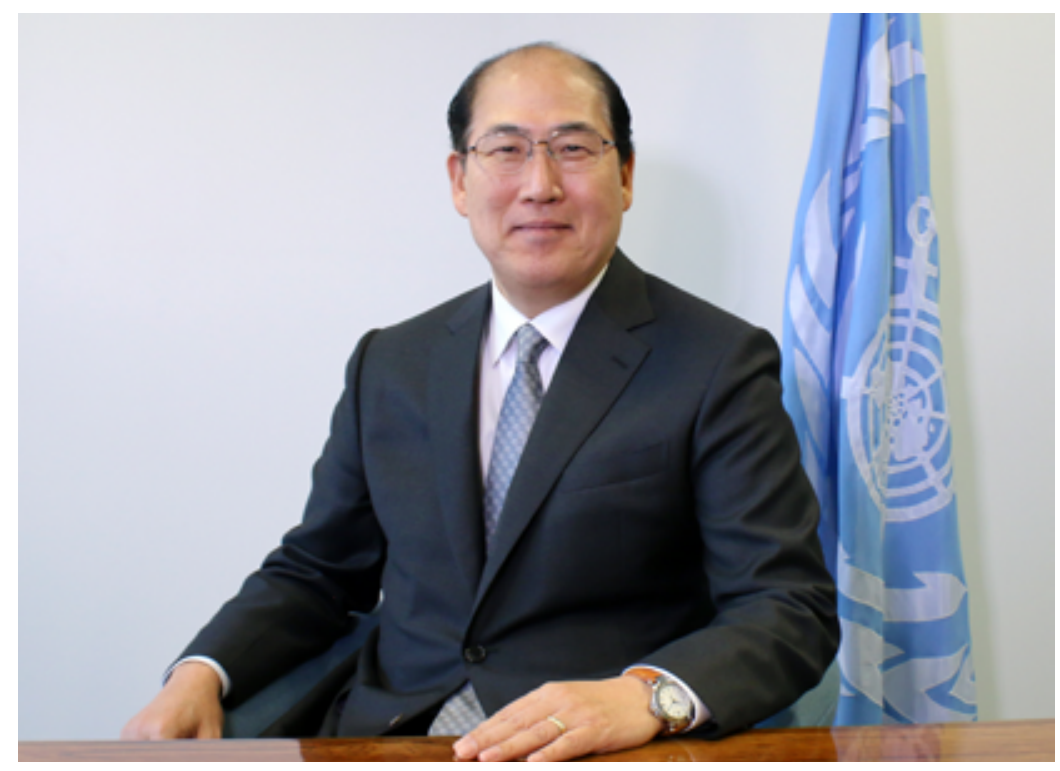

\section{"THE MARITIME WORLD NEEDS ALL HANDS ON DECK - BOTH MALE AND FEMALE - TO CONTINUE TO CARRY THE WORLD'S GOODS IN AN EFFICIENT, SAFE AND CLEAN MANNER."}

MR. KITACK LIM

\section{Mr. Kitack Lim}

Secretary-General, International Maritime Organization (video message)

In his address to the conference, IMO Secretary-General, Mr. Kitack Lim, affirmed the IMO's strong commitment to helping member States achieve the United Nations 2030 Agenda for Sustainable Development, including Goal 5, centred on achieving equality and empowering all women and girls. To that end, the IMO's Women in Maritime Programme has been promoting gender equality in the maritime sector for over 30 years. Mr. Lim reminded the audience that only three decades ago, the doors of maritime training institutes were seldom open to women. Today, although the sector is still largely male-dominated, more and more women are entering the maritime domain in both the public and private sectors. This is in no small part thanks to the IMO's Women in Maritime Programme.

The IMO's commitment is further evident in this year's World Maritime Day theme - "Empowering Women in the Maritime Community". On this platform, the IMO is raising awareness on gender equality in line with the SDGs, and highlighting the important contribution of women to the maritime sector. The Secretary-General wished the Conference participants success, and noted that this Conference would make an invaluable contribution to the Global Women in Maritime programme. 


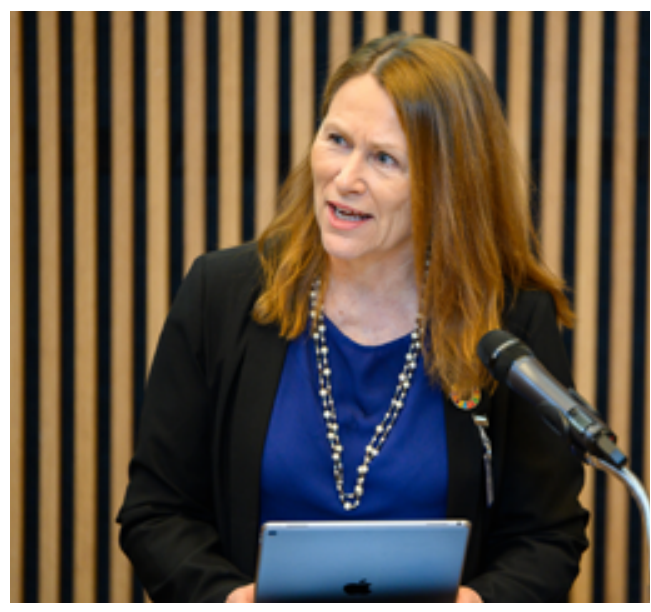

\section{"IT IS SIMPLY TOO IMPORTANT TO LEAVE TO THE MEN ONLY!"}

MS. GRETE FAREMO
Ms. Grete Faremo

\section{United Nations Under-Secretary-General and UNOPS Executive Director}

In her address to the conference, Ms. Grete Faremo described the innate relationship that she has with the sea, having grown up in Norway. For Scandinavians, the sea is a source of food, income, religion, and faith and a bridge to new worlds and opportunities. For the world, maritime transport is the cornerstone of trade, with 80 per cent of trade volume and 70 per cent of its value carried by sea, the inescapable conclusion being that without the maritime community, the world would not be what it is today.

Ms. Faremo discussed the importance of gender concerns in all aspects of the project work of UNOPS, stressing that even small changes can have considerable impacts. A current area of concern for UNOPS is the role of gender-sensitive infrastructure. Ms. Faremo challenged the Conference participants to consider the genderblindness of much of our current infrastructure, including that of the maritime community, and emphasized the need to make infrastructure safe, accessible and unbiased for women in all fields everywhere.

Ms. Faremo reminded the audience how fitting it is for the Conference to be held in this part of the world, where the culture has been built and forged with the maritime community, and where the Swedish Government has adopted a feministic foreign policy. She looked forward to discussing, listening and sharing experiences on how we can empower more women into the modern maritime industry.

\section{Ms. Quah Ley Hoon}

Chief Executive, Maritime and Port Authority of Singapore (MPA)

In her keynote speech, Ms. Hoon highlighted the fact that Singapore pursues and takes action on equal opportunities due to its limited resources and small population, stressing the importance of human capital, and noting that everyone counts. In 2017, Singapore elected its first female President, Madame Halimah Yacob, from the Muslim Malay minority group. Half of all university graduates in Singapore are women. The employment rate for Singaporean women between 25 and 64 increased from 25 per cent in 2008 to 72 per cent in 2018. Ms. Hoon highlighted the importance of policies that ensure equal access for men and women.

In Singapore, the maritime sector has contributed 7 per cent of GDP growth. For example, the Singapore maritime clusters produce over 170,000 jobs (NB: Singapore's population is 5 million) with 5,000 maritime establishments in the country. Like Ms. Hoon, more women in Singapore are entering the maritime industry as seafarers, charterers, operators, ship brokers, lawyers and finance officers. In 
Singapore's Maritime Education and Training (MET) institutions, women represent 20 per cent of the marine engineering diploma cohort and 15 per cent of the nautical studies cohort. In the Maritime and Port Authority of Singapore (MPA), women make up half of the senior management team.

Ms. Hoon concluded her speech with two important points. Firstly, she hopes to see more women in the maritime industry so that in 10 to 20 years' time, we no longer need to discuss the male-dominated nature of the industry. Secondly, she hopes that technological advancement, enhanced efficiency and productivity will open up the job market for women.

\section{Ms. Alette van Leur}

Director of the Sectoral Policies

Department, International Labour

Organization

In her remarks, Ms. van Leur highlighted that in 2019 the ILO was celebrating its centenary. She recalled that the ILO's mandate is to develop labour standards, policies and programmes with the goal of promoting social justice. Equal opportunities for men and women are relevant to the decent work agenda which have been captured in the UN SDGs, in particular, Goal 8 (Decent Work and Economic Growth) and the outcomes of other goals, including Goal 5 (Gender Equality).

The ILO has always given special consideration to the maritime sector, including shipping, fishing and inland waterways. The Maritime Labour Convention (MLC), 2006, was a landmark achievement which brought together nearly all the instruments for seafarers in one single comprehensive Convention. Dr. Doumbia-Henry, WMU President, is recognized as the mother of the MLC, 2006, for her devotion and passion in establishing the new legal mechanism to promote decent work for seafarers.

Women seafarers often face discrimination in accessing employment because of their gender. However, there is no data that proves the stereotype that women do not stay long at sea or that men do not leave the sea prematurely.

\section{"REGARDLESS OF WHETHER YOU ARE A MAN OR A WOMAN, IF YOU CAN DO THE JOB, YOU SEE A VALUE IN IT AND YOU BRING IT TO THE JOB."}

MS. QUAH LEY HOON

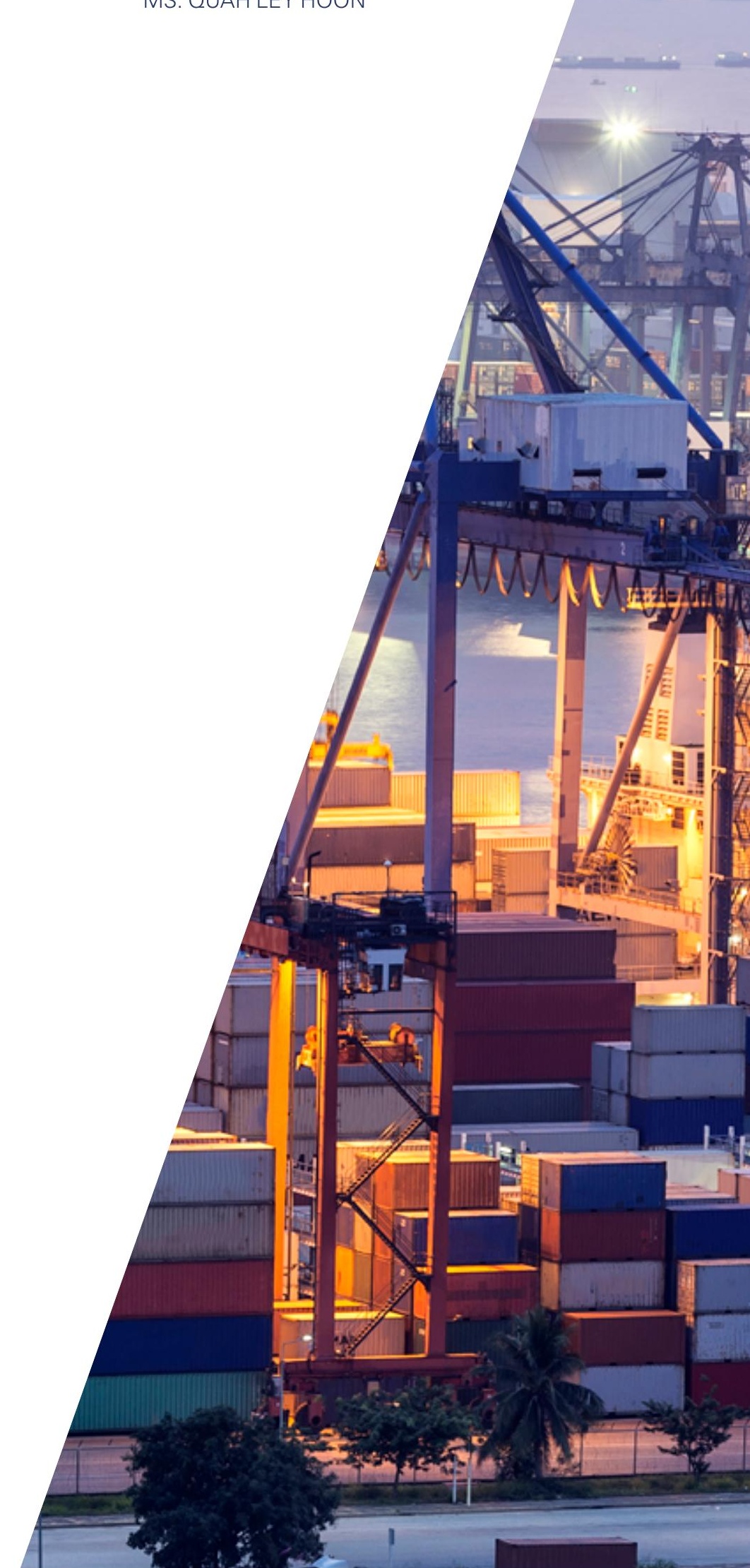




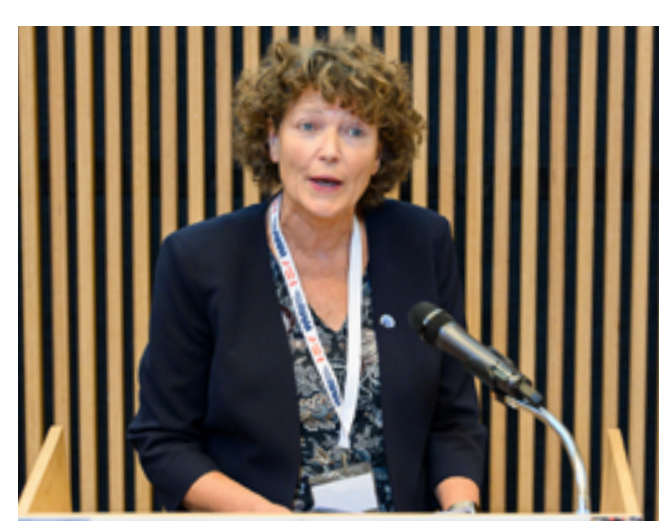

\section{"WE NEED TO CONTINUE TO SHIFT MINDSETS AND FOCUS ON THE STRUCTURE OF BARRIERS."}

MS. ALETTE VAN LEUR
Even after employment, sexual harassment and gender segregation at work appear to be a challenge for women. In February 2019, the ILO held a Sectoral Meeting on the Recruitment and Retention of Seafarers and the Promotion of Opportunities for Women Seafarers, which concluded with a number of recommendations to ensure that women are active participants in decision-making. ${ }^{2}$

Another ILO Convention, Work in Fishing Convention, 2007 (C188), consolidates almost all ILO fishing-related Conventions. According to the World Bank, women account for 47 per cent of the 120 million people working in fishing and its related industries. However, they make up a largely invisible, vulnerable and unpaid workforce due to their unstructured family businesses.

On 8 March 2019, which marks International Women's Day, the ILO published a report "A Quantum Leap for Gender Equality: For a Better Future of Work for All". The report concludes that women are no longer behind men but within reach of attaining gender parity, although it will take quantum leaps, and not incremental steps, to get there. In 1919, the ILO adopted the first conventions on women and work; a century later, women are breaking boundaries that would at one time have been considered impossible. Nevertheless, the maritime world is traditionally identified as a man's world. Women have to adjust to this work environment shaped by men, for men. Struggles for gender equality largely remain a women's issue, which, the speaker concludes, is highly unfair.

Women's voices and leadership still need strengthening and violence eliminated. Transparent policies are preconditions for gender equality in the sector. Ratification and the effective implementation of international labour standards and regulatory frameworks that safeguard equal treatment and non-discrimination are required to ensure a global-level playing field. Women are needed to ensure the sustainable future of the maritime sector.
2 https://www.ilo.org/wcmsp5/groups/public/---ed_dialogue/---sector/ documents/meetingdocument/wcms_674553.pdf 


\section{Dr. Geneviève Béchard}

Hydrographer General of Canada and Director General for the Canadian

Hydrographic Service with Fisheries and Oceans Canada

Dr. Béchard emphasized that gender equality is a key priority in Canada and was the key objective of Canada's Group of Seven (G7) Presidency last year. Canada is committed to taking concrete actions to achieve SDG 5 (gender equality). Dr. Béchard serves as Director General of the Canadian Hydrographic Service, charting Canadian waters, including three oceans - the Atlantic, Arctic and Pacific. Since Canada has the longest coastline in the world, oceans are very important to Canadian culture, its economy and way of life from coast to coast. The world of hydrography is in a transition phase, one moving rapidly towards digitization, which also accelerates machineto-machine services and will enable autonomous ships in Canada by 2050. In that context, Dr. Béchard believes that gender equality is even more important to enable women to take their places in this new world.

In her agency, many women are employed at the entry level, and there are only a handful of women who take up management and executive positions. In the past six months when two senior positions became vacant for recruitment, no women applied or qualified because women lacked the requisite breadth of experience and the competences required. Dr. Béchard urged all stakeholders to take action to enable women with potential and interest to take up the opportunities to develop their skills early enough in their careers.

At the International Hydrographic Organization (IHO), only five countries, Australia, Canada, Croatia, Denmark and Norway, are headed by women. During the Canadian hydrographic conference in Victoria, 2018, 40 female hydrographers came together and established a network of support and mentoring. Many of them have more than 30 years of working experience in hydrography, but had never had an opportunity to share their experiences and guide future generations of women in hydrography.

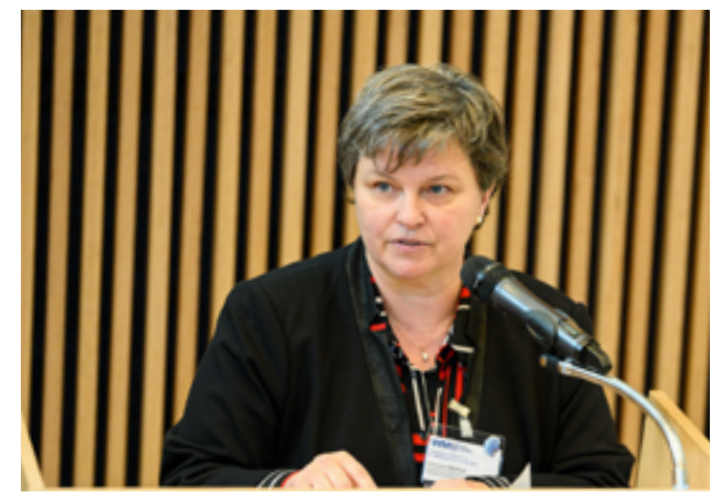

\section{"WE ALSO NEED TO DO THINGS DIFFERENTLY IN ORDER TO PREPARE WOMEN AND HAVE THEM TAKE THEIR PLACE IN THIS NEW WORLD OF DIGITIZATION."}

MS. GENEVIÈVE BÉCHARD

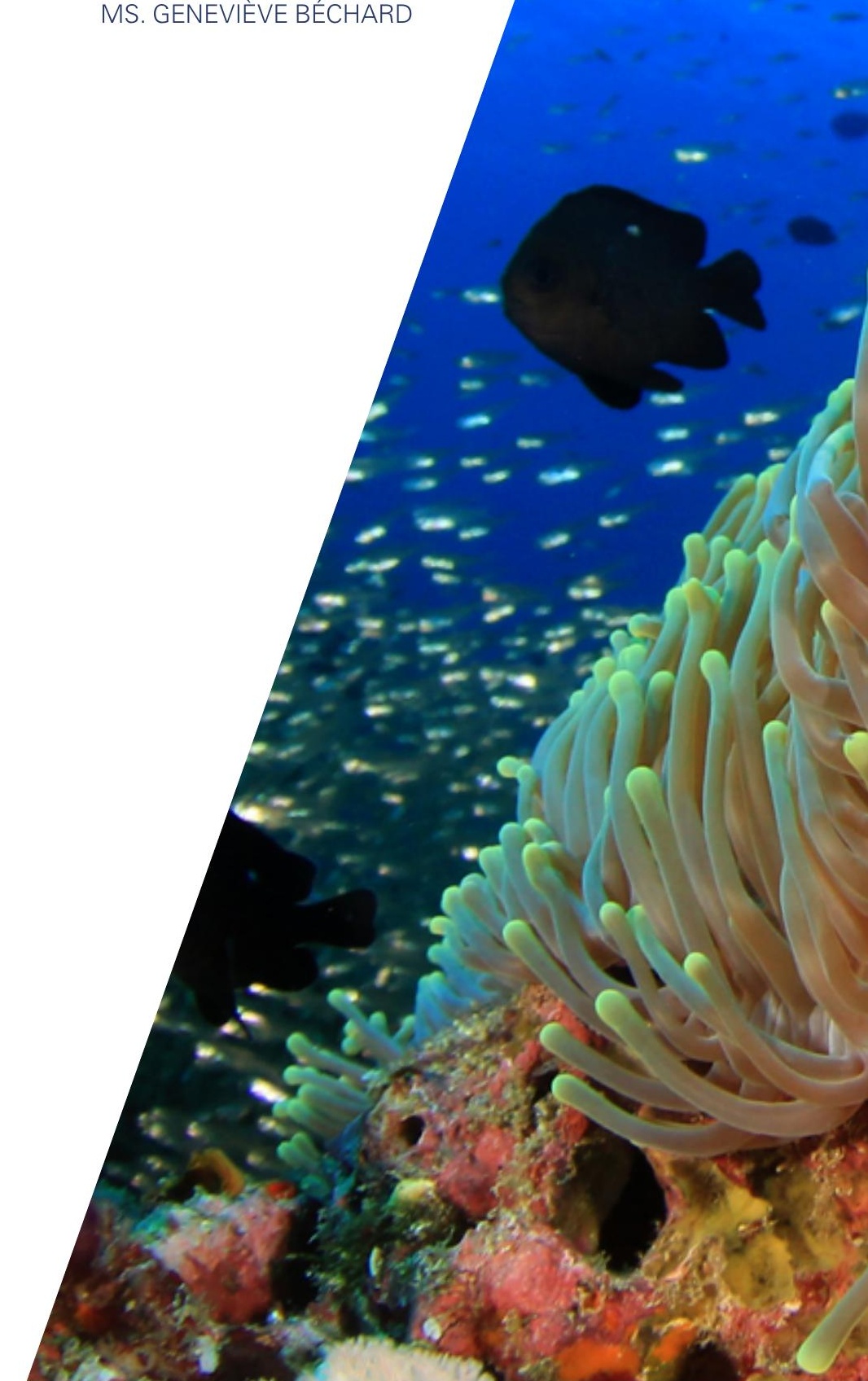




\section{PLENARY SESSIONS}

Keynote speakers were invited to share their knowledge and provide useful advice to women who wished to pursue maritime careers.

Plenary Session 1: Women in Maritime Leadership offered perspectives and insights from women occupying senior leadership positions in national governments and international organizations.

\section{Plenary Session 2: Women's Role in Influencing Ocean}

Governance highlighted the work of professional women leading and influencing interdisciplinary ocean action programmes, with a special emphasis on the long-standing and significant role of women in relation to sustainability-focused ocean governance.

Plenary Session 3: Enabling SDG 5 Towards Sustainable Maritime Industries showcased the contribution of women to achieving sustainable maritime industries.

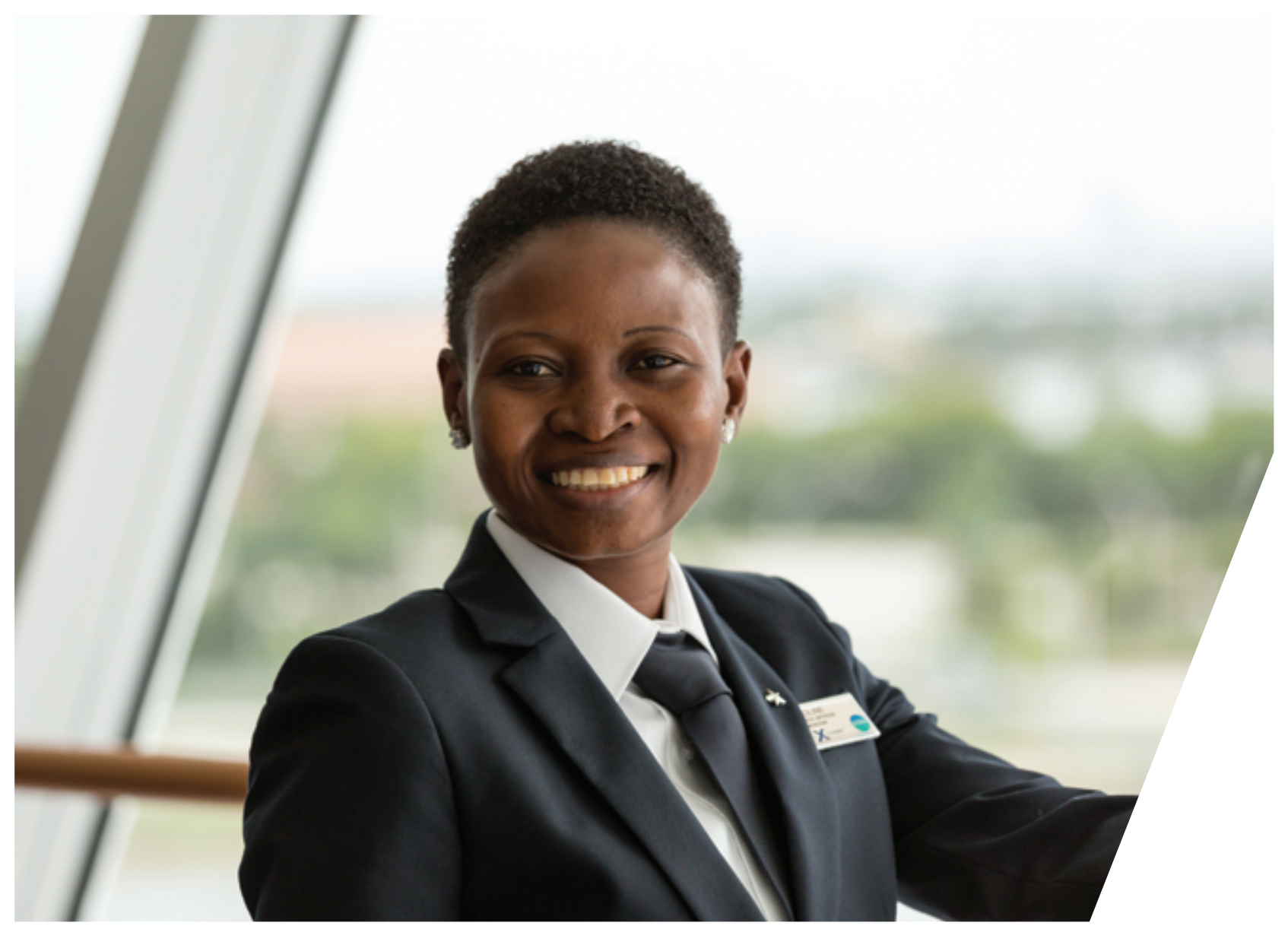




\section{PLENARY 1: \\ WOMEN IN MARITIME LEADERSHIP}

This plenary session highlighted the achievements and experience of trailblazing women who have risen to senior leadership positions in the maritime sector. Women speakers on the panel included leaders in policy-making, decision-making, who implemented activities in fascinating areas in the maritime sector: maritime safety standards-setting, regulation and capacity-building at the international, supranational and national levels. They shared and provided the audience with insights into their journeys to becoming maritime leaders, and offered some important advice and guidance to future maritime leaders. Professor Maximo Q. Mejia Jr., WMU, moderated the session.

\section{Plenary 1: Critical Takeaways and Policy Relevant Highlights}

- Women must be convinced from a very young age to seek a long-term career in the maritime sector.

- A balanced work environment is not only good for workers, it also makes good business sense.

- The maritime industry's image must be improved to promote a more positive impression among the public.
- Legislation must be complemented by frameworks and platforms to promote gender equality.

- Gender equality is a matter of survival because diversity breeds innovation.

- Be confident in your abilities and do not be discouraged by an environment that may not be very supportive from the beginning.

\section{Ms. Heike Deggim \\ Director Maritime Safety Division, IMO}

In her presentation, Ms. Deggim noted that women comprised only about 8 per cent of delegates at IMO meetings and only 28 per cent of the technical officers in the Maritime Safety Division of the IMO Secretariat. While these figures actually represent an upward trend in the participation by women in national delegations at IMO meetings and in the appointment and employment of women in the IMO Secretariat, on board ships and shipping companies, she noted that the situation is still far from the optimal figure of at least 35 per cent.

In addition, more than any open discrimination, the biggest obstacle facing the promotion of women is the scarcity of women applicants to advertised positions. Convincing women from a very young age to seek a long-term career in the maritime sector will go a long way to solving many challenges in the industry, including the shortage of seafarers. In closing, Ms. Deggim offered the following advice to women who wish to pursue leadership positions:

- One cannot allow oneself to be unsettled by every outlandish remark made. It is better to ignore it and move on.

- $\quad$ One needs to pick the fights one can win. It is no use wasting time and energy on things that are not worth fighting for.

- One does not have to sacrifice a family life in order to move forward with a career in shipping. I brought up two children largely on my own while climbing up the career ladder. I am now blessed with three grandchildren I am very proud of. While that was not always easy, it is doable. One needs the will to succeed and also a good network of family and friends to help out.

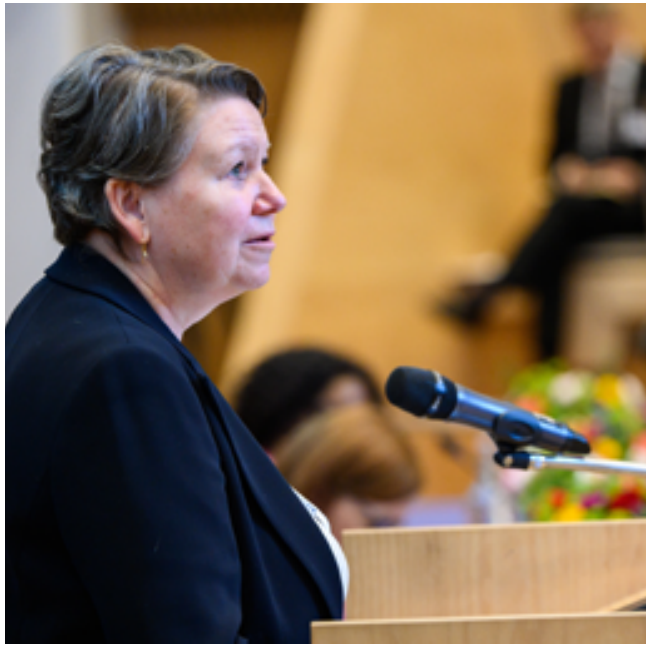




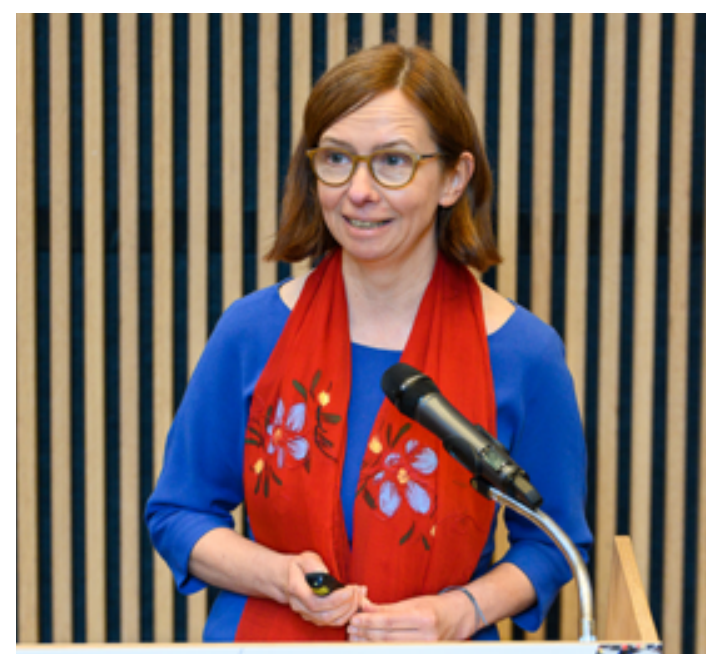

\section{Ms. Magda Kopczynska DG MOVE, EC}

Ms. Kopczynska shared some perspectives and insights from the European Commission (EC) in the context of women in maritime leadership. She emphasized the need for gender balance in the workplace. In fact, she underscored that a balanced workplace is not only good for workers, but also for employers. Studies have shown that balanced and inclusive workplaces are more successful and are better at achieving their targets. They are twice as likely to meet or exceed their financial targets, three times as likely to be high performers, six times more likely to be innovative and agile and eight times more likely to have better business outcomes.

Commenting on the snail pace of progress in attracting women to the maritime sector, Ms. Kopczynska mentioned that public perceptions of the industry are far from favourable. The European Commission surveyed young people on their perceptions of the transport sector and found not only that the maritime sector was not a top choice for young people between 16 and 28, but also that it had connotations of being unknown, slow, lonely and dirty. According to the youth surveyed, the person that still epitomized the maritime sector is the "old, bearded, tattooed sailor."

It is clear that such perceptions must change if a maritime career is to become a preferred choice among young men and women. Legislation alone is insufficient. Frameworks that will promote good solutions are just as necessary. In that regard, the EC established "Women in Transport," a platform that elicits the commitment of businesses, companies and associations to join together and (a) make bold targets, declarations, and commitments, and (b) promote forward-looking cases such as Stena Line which has committed to have 30 per cent women working in the company by 2022.

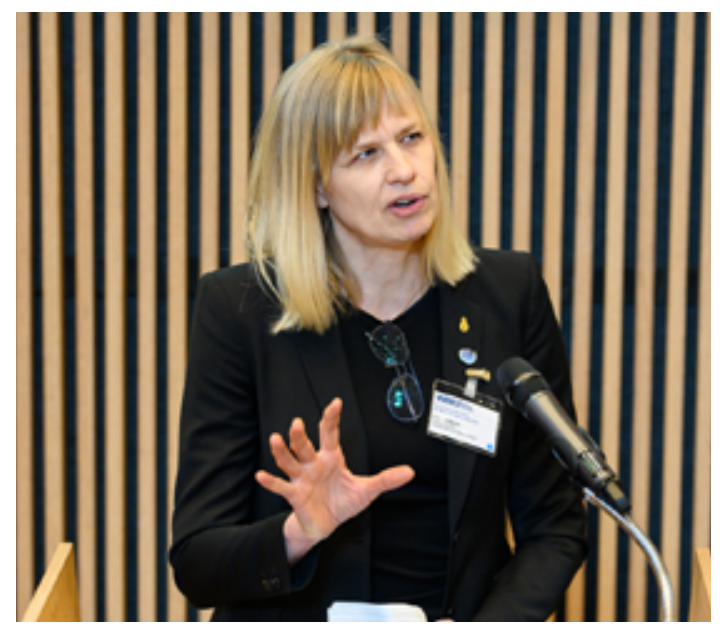

\section{Ms. Katarina Norén}

Director General, Swedish Maritime Administration

Ms. Norén began her presentation by stating that gender equality is a matter of survival because diversity breeds innovation. Even in Sweden, where gender equality is more advanced, with 12 of 22 government ministers being women and where the government has a Minister for Gender Equality, only 4 per cent of those working in the maritime industry are women. In her own Agency, only 8 of 220 pilots are women. To address this situation, the maritime industry has joined together in Fairways, a major project where top management signs a letter of intent to look at gender inequality as a work environment problem and a matter of survival. Fairways organizes seminars, workshops, research and development and promotes role models and examples to promote more women in the maritime industry. 
Despite all these efforts and the country's progressive achievements, Ms. Norén admits that Sweden is still far from achieving its gender equality targets. The practical advice that she shared included the following points:

- Work hard and take on the available opportunities, and make the best of it.

- Choose your husband! I would never choose a husband who would not let me have a career and would not do half the work at home.

- At work, do not identify yourself as a woman, rather identify yourself as a professional.

- If possible, choose your boss.

\section{Ms. Maphefo Anno-Frempong,}

\section{CEO, Transport Education Training Authority, South Africa}

Ms. Anno-Frempong began her presentation with a description of Operation Phakisa (phakisa being a Zulu word that means "do things quickly"), which is designed to generate more jobs and a globally competitive maritime/ocean economy through skills development. She gave her personal testimony that she joined the transport sector by chance and succeeded by dint of faith and belief that one can achieve anything to which one sets one's heart and mind

Ms. Anno-Frempong shared her conviction that, "it is because of that belief that I have been able to survive in an environment that did not necessarily embrace me in the beginning. I had to kick some doors open to be embraced, and I am still kicking them, determinedly. I encourage any woman that wants to make a difference in life, let passion and purpose drive you. There is nothing that defies purpose." She feels truly blessed to be leading the team she leads and feels fortunate to work with ministers that are supportive of empowering women. She concluded her presentation with the following advice:

- In life, you will never please everyone. Do not try. But, always be driven by integrity, by honesty and by your principles.

- My advice to other women is do not kick the ladder from under those who are coming behind you. But be kind to yourself and do not take yourself too seriously. But master yourself in the process, and also show up and embrace the journey.

- Invest in others and make progress.

- Above all, just stand on the shoulders of those who have gone before you.

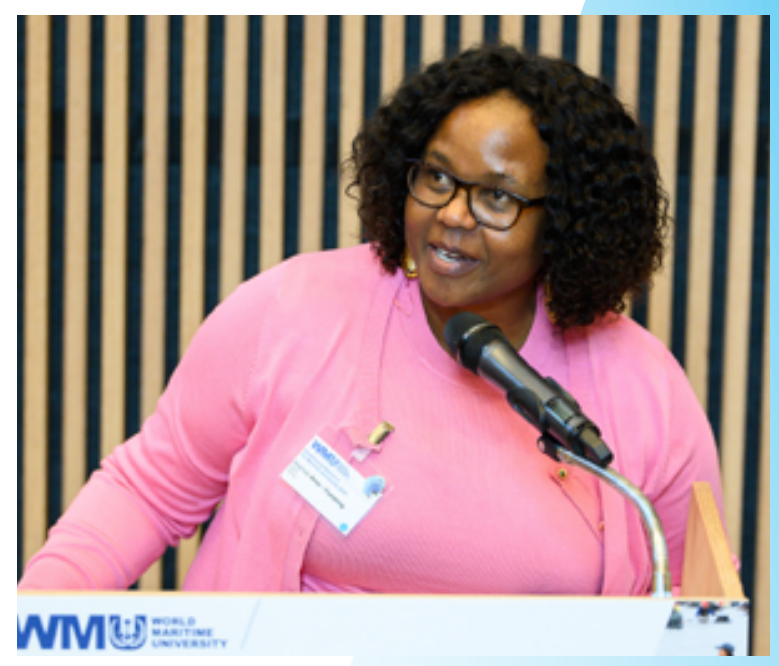




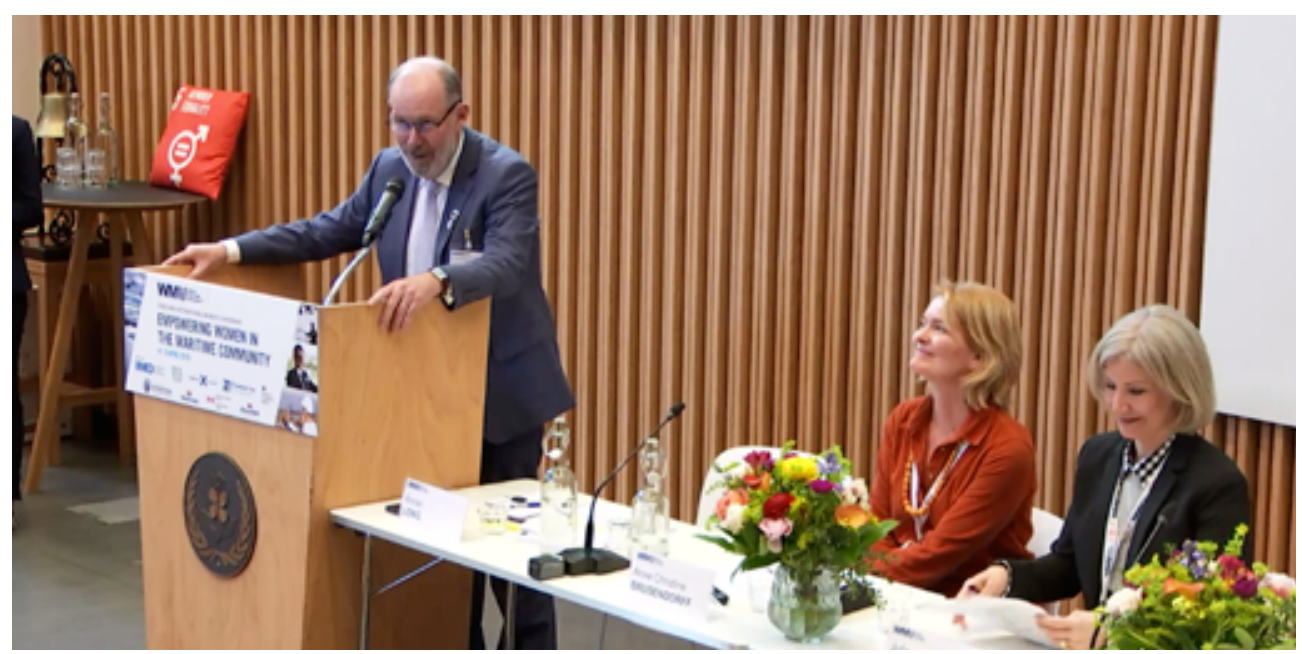

\section{PLENARY 2:}

\section{WOMEN'S ROLE IN INFLUENCING OCEAN GOVERNANCE}

This plenary focused on highlighting the work of professional women leading and influencing interdisciplinary ocean action programmes, with a special emphasis on the long-standing and significant role of women in relation to sustainability-focused ocean governance. The session was moderated by Professor Ronán Long, Director, WMUSasakawa Global Ocean Institute of WMU.

\section{Plenary 2: Critical Takeaways and Policy Relevant Highlights}

- It is important to seize the opportunity to effect positive change when opportunities arise.

- Discussion across all levels among all genders is vital, including the importance of establishing support teams that should also include men.
- A life role model is important for setting good examples, which is key, as well as sharing the experience of how to face and address real challenges.

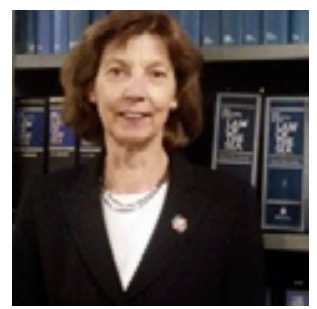

\section{Ms. Gabriele Goettsche-Wanli}

Director, United Nations Division of Ocean Affairs and the Law of the Sea (DOALOS) (video message)

Ms. Gabriele Goettsche-Wanli, Director of DOALOS, addressed women's role in decision-making at the global level. On the one hand, there are a vast number of commitments in legal and policy instruments with regard to the rights of women to full, effective and equal participation in decisionmaking. Legal or policy discussions that take place without the meaningful participation of women can increase existing inequalities and vulnerabilities and decrease effectiveness as demonstrated by trends in the public and private sectors. The available data indicates that, currently, in many parts of the world women's ability to participate in decisionmaking processes is curtailed due to a number of factors including limited access to and control over income, credit, land, education, training, healthcare and information. 
On the other hand, Ms. Goettsche-Wanli reminded the audience of the importance of taking the gender dimension into account in all decision-making processes. Fewer women than men are involved in oceanrelated sectors. When employed, women often face discrimination and harassment. Their work is often informal, uncompensated and unregulated and thus, overlooked in official programmes. The scarcity of gender disaggregated data serves as a constraint on gender sensitive policies and mainstreaming with little action taken to address existing inequalities and vulnerabilities.

Women's inability to participate equally and meaningfully in decision-making processes relating to the oceans at the local and national levels also affects their participation at the international level. For example, the division noted by DOALOS with respect to some of its intergovernmental meetings illustrates that although women comprised on average 41 per cent of the total participants in 2018 and women were among the presiding officers, only 32 per cent of the participants represented as heads of delegations were women.

Moreover, women in member State delegations comprised only one-quarter of the senior positions. Data maintained by the division also indicates that only 28.5 per cent of the members of the pool of experts of the second cycle of the regular process nominated by States to assist in the preparation of the Second World Ocean Assessment are women, with some regions being severely underrepresented. To date, only a marginal improvement has taken place in the numbers since the preparation of the First World Ocean Assessment during the first cycle of the regular process.

In addition to the aforementioned, women are also highly underrepresented in the bodies established by the United Nations Convention on the Law of the Sea, in particular in the Commission on the Limits of the Continental Shelf and in the International Tribunal for the Law of the Sea, which implies that one gender is inadequately represented when decisions that carry great authority in the Law of the Sea are made.

Gender equality, also a fundamental human right in and of itself, is thus far from having been realized. Concerted efforts are therefore required to ensure that there is equal access to quality education, economic resources, political participation and equal opportunities for employment, leadership and decision- making at all levels. The United Nations 2030 Agenda for Sustainable Development recognizes that the achievement of full human potential and sustainable development is not possible if half of humanity continues to be denied its full human rights and opportunities.

To that end, SDG 5 sets out a number of targets to achieve gender equality and women's empowerment. Although the primary responsibility to achieve gender equality and women's empowerment rests with States, there are actions we can all take to create a tidal wave of change, in particular the enhancement of education and economic status can provide better conditions for accessing equal, full and meaningful participation in decision-making. This will inevitably lead to the adoption of more effective laws and policies in support of women's empowerment, and the protection of rights and remedies for violations.

At the level of the United Nations system a number of initiatives are underway to promote gender equality and women's empowerment, for example, the provision of information, training and other capacitybuilding tools, networking and financial support. DOALOS's activities to promote gender equality and empowerment of women include the provision of information, in particular through the reports of the Secretary-General of the Oceans and the Law of the Sea and capacity-building. Its training courses and the United Nations-Nippon Foundation Fellowship Programmes have greatly benefited from gender equality among participants.

A vital step towards achieving progress is awareness-raising, since currently the importance of gender equality and the empowerment of women for effective ocean governance is not well understood. It would benefit from in-depth analysis and consideration at all levels, including the intergovernmental level. This would stimulate the collection of data and information encompassing all relevant ocean sectors and activities bearing in mind also other relevant factors, including societal norms, culture, economic, financial and political aspects, as well as law and policy and their interactions.

Such data and information can, in turn, help policy-makers target priority areas, track progress and set targets and indicators to measure progress and identify areas requiring international cooperation. Consideration could also, for example, be given to the adoption 


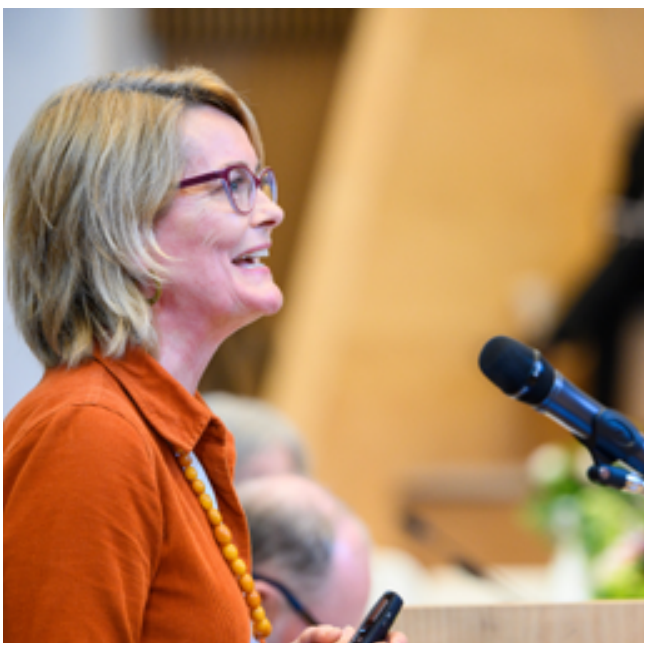

of a Gender Action Plan at the intergovernmental level. This is the approach taken by the parties to the United Nations Framework Convention on Climate Change that adopted a Gender Action Plan in 2017 to seek to advance women's full, equal and meaningful participation and promote gender responsive climate policy and the mainstreaming of a gender perspective in the implementation of that Convention, and the work of the Parties, the Secretariat, United Nations entities and stakeholders at all levels.

She indicated that conferences provide a valuable opportunity for catalyzing action. For example, the 2017 United Nations Oceans Conference led to the registration of 115 voluntary commitments that have, as their stated aim, the promotion of gender equality. This year, an important opportunity for awareness-raising is also provided through the IMO's World Maritime Day with its focus on empowering women in the maritime community. In addition, the World Oceans Day, which is commemorated annually at United Nations Headquarters on 8 June, and this year the activities that DOALOS coordinates will focus on the theme, "Gender and the Ocean".

\section{Dr. Anne Christine Brusendorff}

General Secretary, International Council for the Exploration of the Sea

Dr. Anne Christine Busendorff serves as General Secretary of the International Council for the Exploration of the Sea (ICES), which has a legal framework that provides for scientific cooperation among the member States for ocean exploration. Immediately after entering office in 2012, Dr. Busendorff faced three challenges: not having previous work experience with ICES, entering a natural science work community with a law background and being the first female in 110 years to lead the organization.

In terms of gender-balance composition, ICES has improved over the years. In 2019, less than 25 per cent of the delegates within the ICES Council were women. Its 20 member countries can appoint two delegates, which presents an opportunity to strike a gender balance. The two subordinate committees, the Advisory Committee (ACOM) and the Science Committee (SCICOM) have more than 20 per cent and 25 per cent women employees respectively. As for the ICES working groups, which are the engine of the entire organization, one-third of the chairs are women. However, there are currently no gender-related data with respect to participants within the expert working groups. Nevertheless, the assumption is that the number of women in the working groups is higher than expected. As for training courses, Dr. Busendorff observed that an even balance between female and male participants existed between 2009 and 2014.

The ICES Secretariat, which has its offices in Copenhagen, has 60 colleagues from 27 different nationalities with more women than men. When looking into the different categories of work carried out by the Secretariat, the general service category has the highest number of women employees, whereas the professional category, where strategic decisions are taken, has a high number of male employees.

Science helps develop society and is an important information source. Given its invaluable role, the speaker stressed the need for science to be unbiased, respectful of the law and objective and to ensure 
that a proper representation of both women and men exists. When looking at ocean governance, gender balance is likewise an underlying condition and must be made explicit. The ICES Strategic Plan issued in 2019 listed relevant issues. In order for ICES to be a world leading organization that provides society with impartial evidence for sustainable use of the oceans, it must be inclusive and genderbalanced. Achieving that goal will require a number of initiatives, including collaboration across genders, mutual support through mentorship and recognition by all genders of the need for diversity in science and its contribution to ocean governance.

\section{Ms. Julie Gascon}

\section{Director General of Operations, Canadian Coast Guard}

Ms. Gascon began her presentation with a positive remark that Women's Role in Influencing Ocean Governance is an important conversation where each of us brings insight, based on diverse professional experience and interdisciplinary perspectives on ocean governance. This is a broad and complex topic that encompasses policy and the action of States, and brings together multiple stakeholders to protect the ocean and promote biodiversity and sustainable use of resources.

The Canadian Coast Guard is a special operating agency within Fisheries and Oceans Canada and is responsible for safeguarding Canada's waters and managing fisheries, oceans and freshwater resources. Its focus is on supporting a healthy environment and sustainable aquatic ecosystem. As the Director General of Operations, Ms. Gascon is responsible for all operational aspects of Canadian programmes across the country. Canadian Coast Guard vessels and personnel help protect fish stocks by supporting fisheries patrols, and support scientific surveys and hydrographic missions.

The Canadian Coast Guard is an operational organization that provides key ocean and waterways management services for the safe movement of ships in Canadian waters. It is also involved in influencing Canadian federal policies in ocean governance. For example, the 2016 Oceans Protection Plan, is a CAD1.5 billion investment that embodies activities in relation to making the maritime community more inclusive. Currently, the Canadian Coast Guard is integrating a gender-based analysis to its recruitment and retention programme.

To become more inclusive in an organization, it is important to recognize those who break down barriers. History reveals that women have already been involved in the social, economic and cultural interaction with water. However, their contributions are not always known and that is why change is needed in order to strengthen ocean governance. 


\section{PLENARY 3: \\ ENABLING SDG 5 TOWARD SUSTAINABLE MARITIME INDUSTRIES}

This plenary session focused on successful initiatives toward gender equality in the maritime sector by government and industry, with examples from South Africa and Stena Lines. Speakers highlighted achievements, but also emphasized the need for further work by individuals, international organizations, government entities, industry and other stakeholders at all levels in driving forward the diversity and gender equity agenda toward a sustainable maritime sector. Ms. Lena Dyring, Director of Cruise Operations, Norwegian Seafarers' Union, moderated the session.

\section{Plenary 3: Critical Takeaways and Policy Relevant Highlights}

- Gender equality is not just a women's issue, but is key to business growth and prosperity.

- The evolution of the maritime sector, driven by the Fourth Industrial Revolution and sustainability initiatives, presents new opportunities for women's engagement.
- $\quad$ Female role models and mentors are essential in making the maritime industry more approachable for women and girls, especially in the seafaring profession.

- Government, industry and educational institutions must remove barriers and support women's participation in the maritime sector by integrating gender equity and inclusion into policymaking.

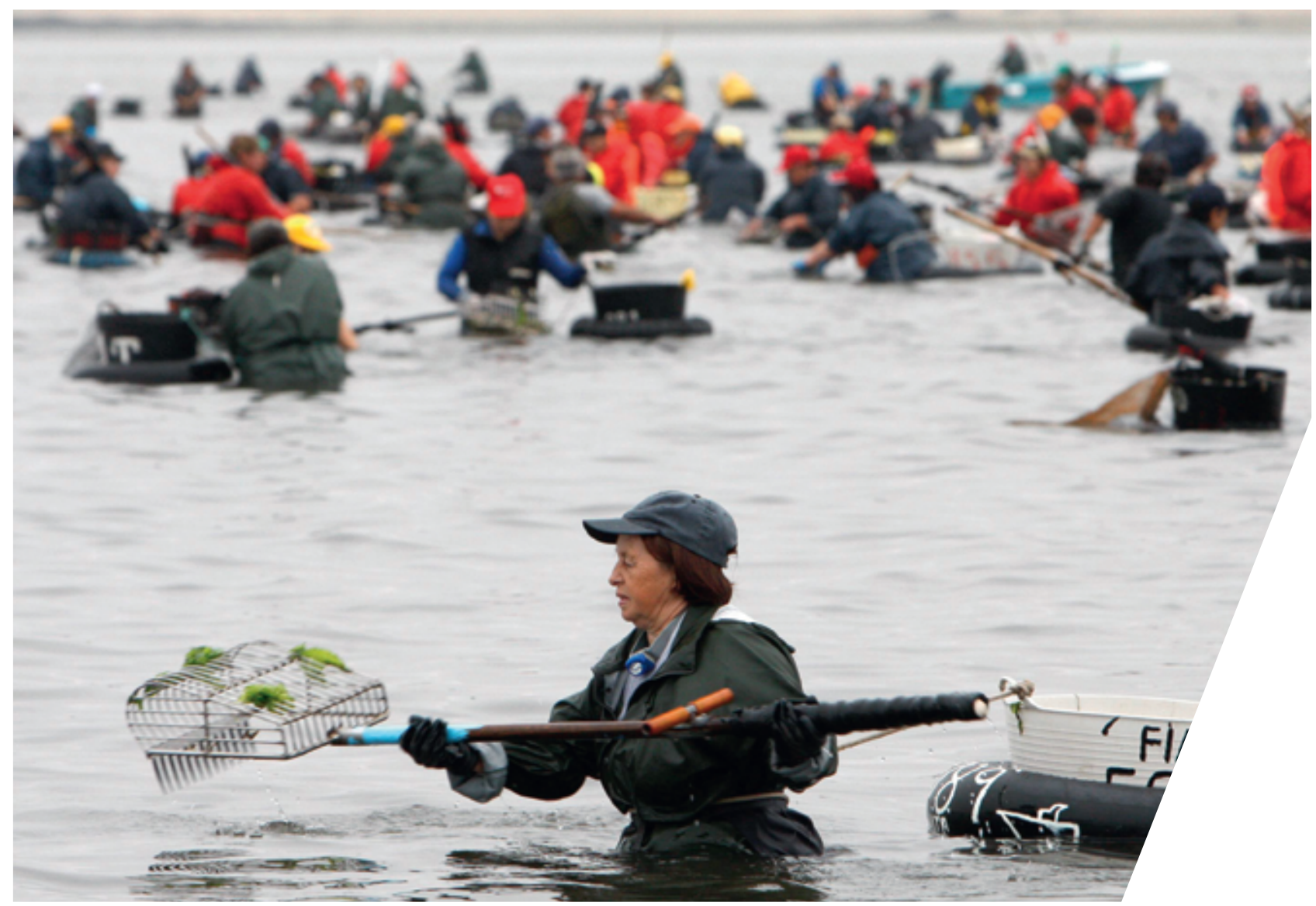




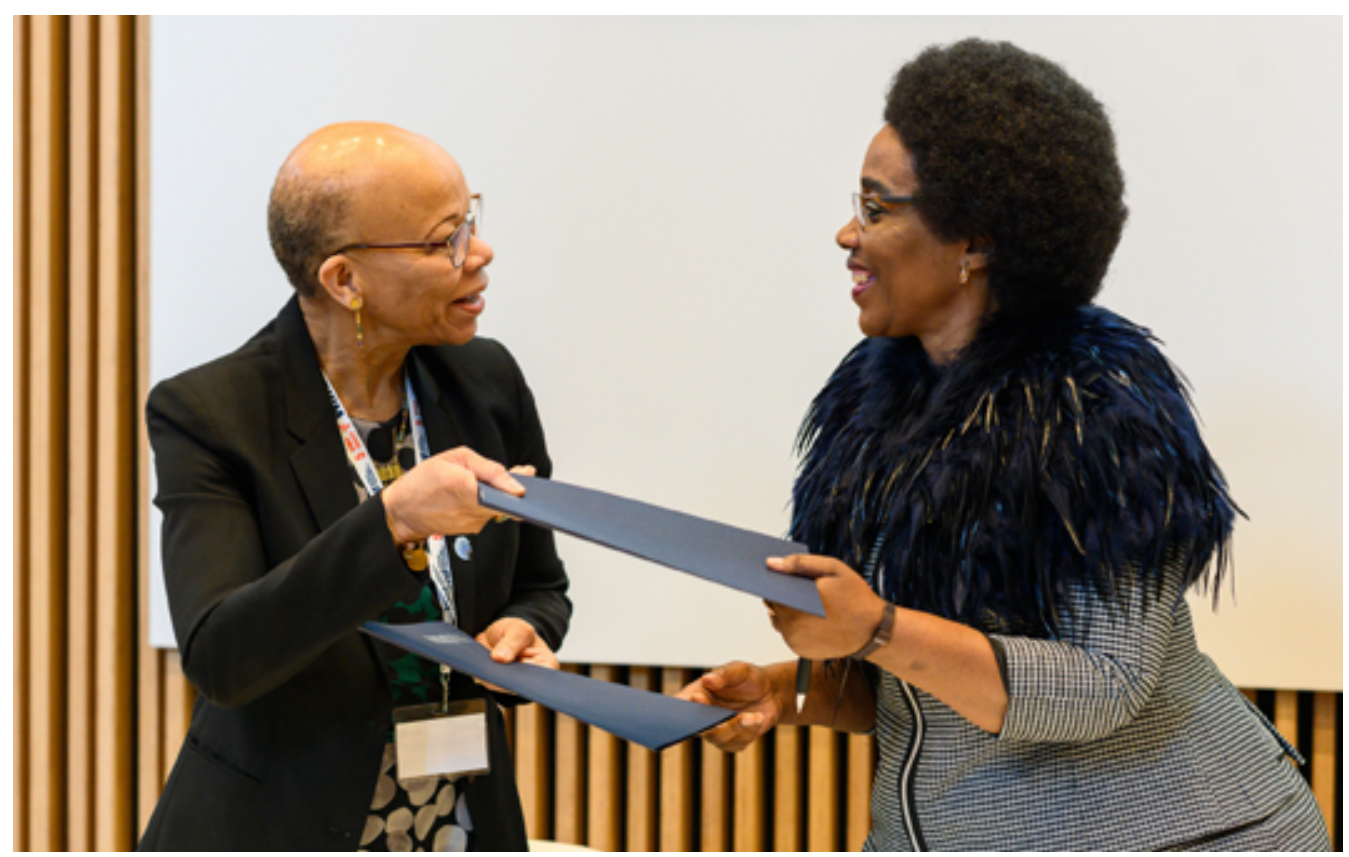

\section{Ms. Sindisiwe Chikunga}

Deputy Minister of Transport, Government of South Africa

Ms. Chikunga's presentation focused on South Africa's progress in the maritime sector, and on maritime women's success and empowerment. She recalled that when she assumed office as the first female Deputy Minister of Transport in South Africa's history in 2012, the maritime sector was largely overlooked both in terms of its significance to the country's economy and as a target for transformation. Recognizing South Africa's potential as a maritime nation and port State, she proposed that 2013 be declared "The year of maritime", and undertook to elevate the status of the maritime sector, especially in national policy discussions, and to identify and address areas for growth.

In 2014 these initiatives culminated in the adoption of Operation Phakisa, South Africa's multi-stakeholder-driven ocean economy strategy. Ms. Chikunga highlighted the critical role of skills development and employment agendas that target women and the ascension of women into strategic positions, including politics, referring to several notable firsts, including the country's first black female Harbour Master, Captain Precious Dube. Ms. Chikunga urged the audience to persevere with the transformation and gender equity agenda:

"ABOVE ALL, WE AS WOMEN WORKING TOGETHER WITH OUR MEN MUST LEAD, MUST MANAGE, MUST INITIATE, MUST FIGHT, MUST CAPACITATE, AND BE THE CHANGE ENGINES REQUIRED BY A MARITIME SECTOR WITH THE ADVENT OF THE FOURTH INDUSTRIAL REVOLUTION. WE MUST NEVER GIVE UP".

MS. SINDISIWE CHIKUNGA 


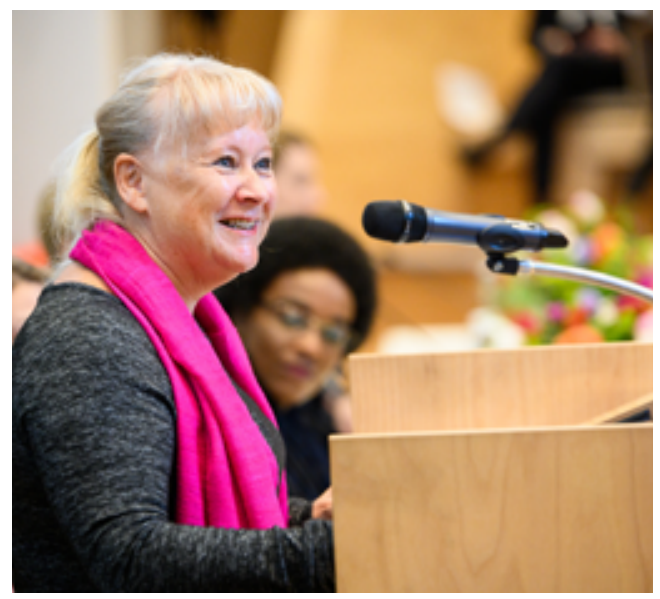

\section{Ms. Birgit Sølling Olsen}

Former Deputy Director-General, Danish Maritime Authority

In her presentation, Ms. Olsen stressed that a woman's

empowerment begins with herself. Women need to create their own career paths by bringing themselves forward, accepting challenges, obtaining the right qualifications and constantly improving them. Confidence, persistence, and willingness to take chances are all part of the mindset that, according to the speaker, is necessary for women's empowerment and success. On the other hand, the movement toward equality cannot be carried by women alone.

Ms. Olsen emphasized the importance of taking active measures, of going beyond words. She exhorted companies to take action by setting specific gender equality goals and policies, such as those in Denmark, which have seen female participation on boards of top companies increase from 9.5 per cent to 27.5 per cent in less than 10 years. For the empowerment of female seafarers the industry must become more accessible and attractive to women. This requires specific and transparent goals at maritime academies and employment policies that protect women's rights, including the right to maternity leave. It is no longer possible or profitable to ignore 50 per cent of the world's population or to use only 50 per cent of its talent. Equality brings prosperity, but progress toward equality has been slow, and there is room for improvement.

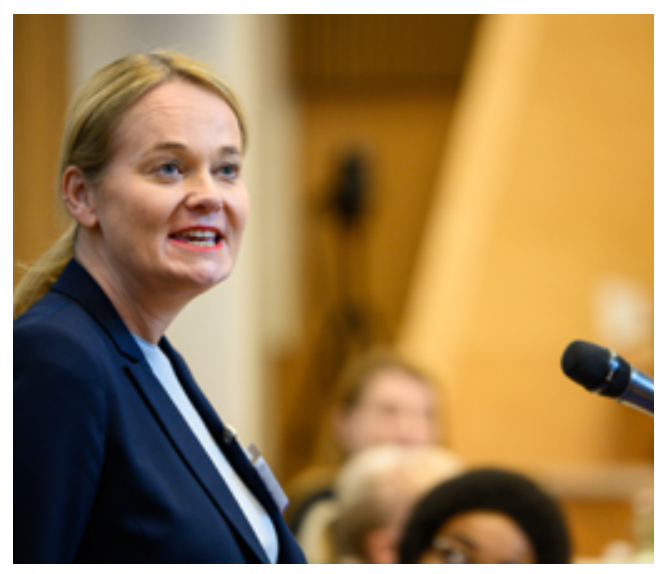

\section{Ms. Margareta Jensen Dickson}

\section{Head of People, Stena Line}

Ms. Dickson shared Stena line's vision to be a leader in sustainable shipping. Three years ago, the company introduced four sustainability areas: health and well-being, clean energy, responsible consumption and life below water. According to the speaker, a great deal of action has come out of the company's work in these areas, resulting in improved processes and ways of working. On 8 March, International Women's Day, Stena Line introduced equality and inclusion as a fifth sustainability area.

To drive change in the area of gender equality, the company set specific targets. By 2022, 30 per cent of management positions should be filled by women and 30 per cent of new recruits should be women. Stena Line also aims to become a harassment-free workplace, with a goal of zero cases of harassment by 2022. Ms. Olsen reviewed current statistics for women working in deck and engine departments on the company's vessels ( 2.9 per cent) and in leading positions (16 per cent). She concluded that, while there is a long way to go, Stena Lines is currently striving for a way forward to become a family friendly company and a Scandinavian leader in sustainability. 


\section{Ms. Despina Panayiotou Theodosiou}

President, Women's International Shipping and Trading Association (WISTA)

Ms. Theodosiou discussed opportunities to enhance the participation of women in the maritime sector emerging from the transformational drivers of the Fourth Industrial Revolution and sustainable shipping initiatives. Women are integral to the transformation and modernization of the maritime sector, and they are poised to take up the new roles and new jobs offered by technological innovation, digitalization and new ways of doing business. The speaker advocated a nuanced approach to enhancing diversity and equality, and offered a number of ideas aimed at removing barriers to participation and attracting more girls and women to the maritime industry.

Ms. Theodosiou highlighted the need to address societal barriers in positive ways; build up gender equality and a neutral selection process in schools and jobs; and ensure that girls and women are supported in, and aware of, the opportunities available to them. She also emphasized the need for more female role models and mentors to make the maritime industry more approachable to women. Ms. Theodosiou concluded that while we are on the right path to ending discrimination and promoting diversity, much remains to be done at the individual, industry, organization and government levels to facilitate the uptake and retention of women in the maritime sector:

\section{"ALL ASPECTS OF SOCIETY NEED} TO REALIZE THE BUSINESS BENEFITS OF DIVERSITY AND EQUALITY. THIS CANNOT BE SEEN AS A BATTLE, A WAR OR A STRUGGLE - THIS IS ABOUT IMPROVING SOCIETIES, INDUSTRIES AND PROVIDING OPPORTUNITIES FOR ALL".

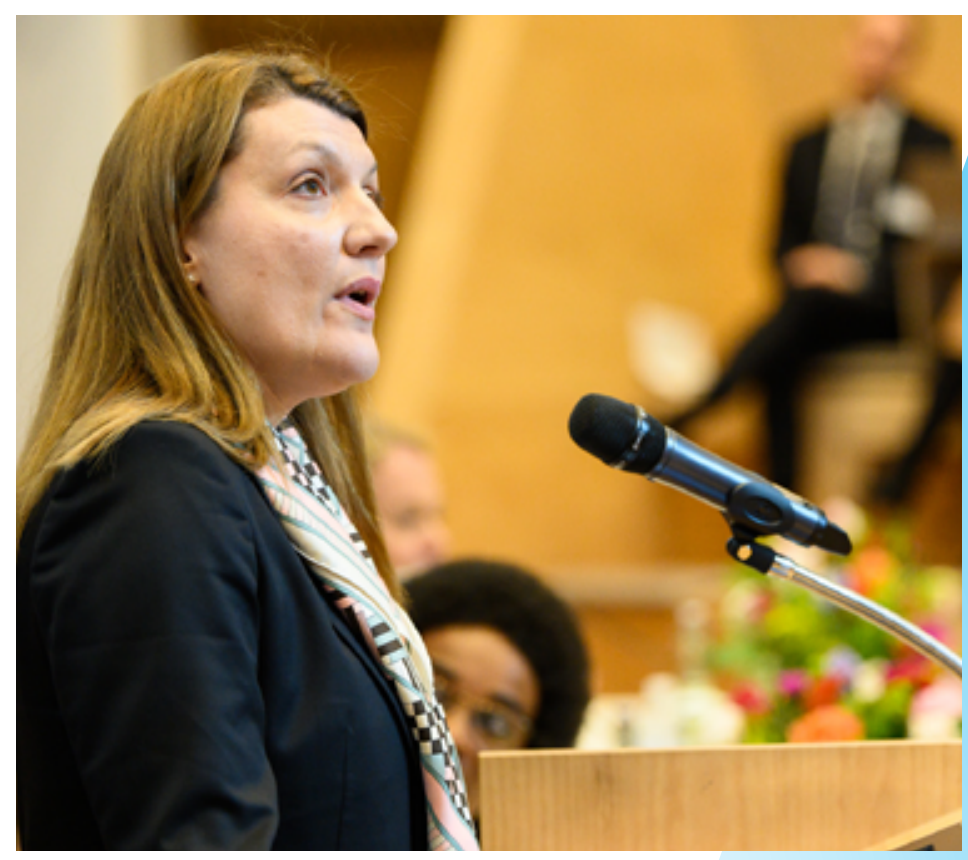

MS. DESPINA PANAYIOTOU

THEODOSIOU 


\section{PANEL SESSIONS}

The Conference offered four thematic panel sessions from different maritime and ocean sectors and one consolidated panel session:

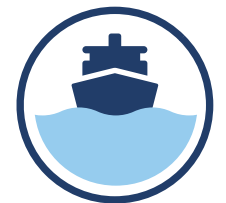

Panel A: Women in Shipping focused on the role of women in the shipping industry, the achievements to date and the challenges ahead.

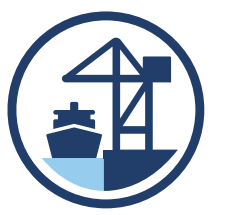

Panel B: Women in Ports highlighted the role undertaken by women at various seaports, heading operations, business analysis and corporate social responsibility, among others, in developing sustainable ports and society.

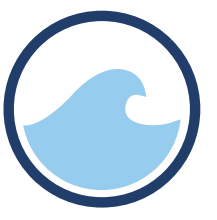

Panel C: Women in Ocean and Marine Science showcased women from varying career levels who are proactively engaged in ocean and marine science activities to discuss the role of equity, gender-balance and inclusion for greening the blue economy.

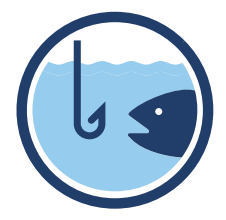

Panel D: Women in Fishing and Seafood Harvesting highlighted the contribution of women to the fishing and seafood harvesting sector.

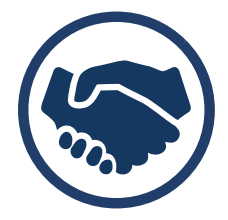

Panel E: Partnerships and Networking for Gender Equality brought together all four themes (shipping, port, ocean and marine science, fishing and seafood harvesting) to focus on good practices in partnerships and networking for the achievement of gender equality. 

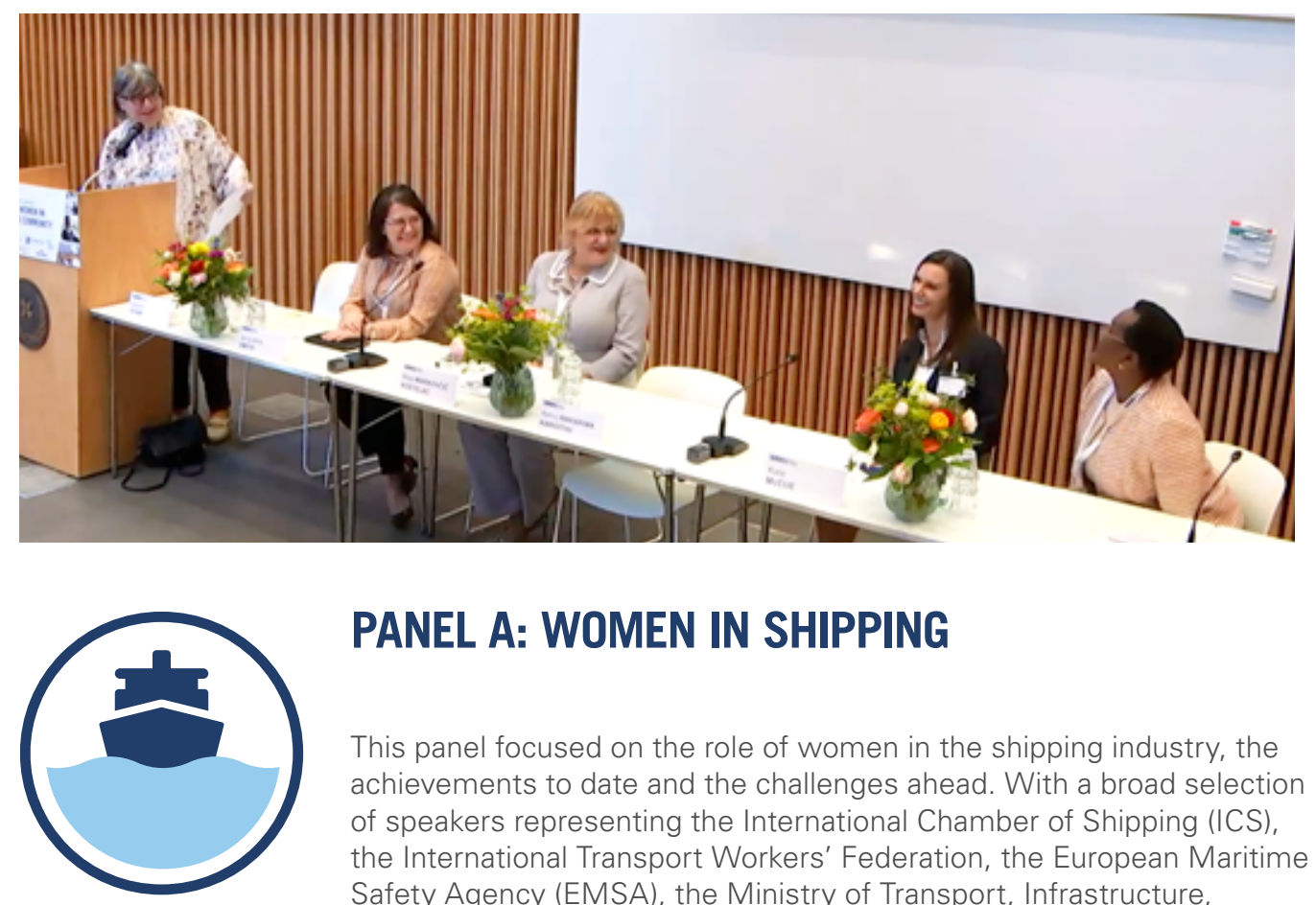

\section{PANEL A: WOMEN IN SHIPPING}

This panel focused on the role of women in the shipping industry, the achievements to date and the challenges ahead. With a broad selection of speakers representing the International Chamber of Shipping (ICS), the International Transport Workers' Federation, the European Maritime Safety Agency (EMSA), the Ministry of Transport, Infrastructure, Housing and Urban Development and Public Works in Kenya, and Celebrity Cruises.

Speakers shared the view that the attributes of excellence and competence required for maritime jobs are irrelevant to gender. Biases towards women in the shipping industry are still the major barrier to gender equality. In order to build an image of strength and resilience for the shipping industry, a brand needs to be created of a young, dynamic and attractive profession. Ms. Natalie Shaw, Director, Employment Affairs, International Chamber of Shipping (ICS) moderated the panel.

\section{Panel A: Critical Takeaways and Policy Relevant Highlights}

- Diversity is a key to promoting gender equality and helps to bring the best talents to the maritime industry.

- Branding the maritime industry is important to attract young people.
- Using a social media platform is an effective way to promote the maritime industry and women professionals.

- Increasing women's access to education and training is effective capacity-building. 


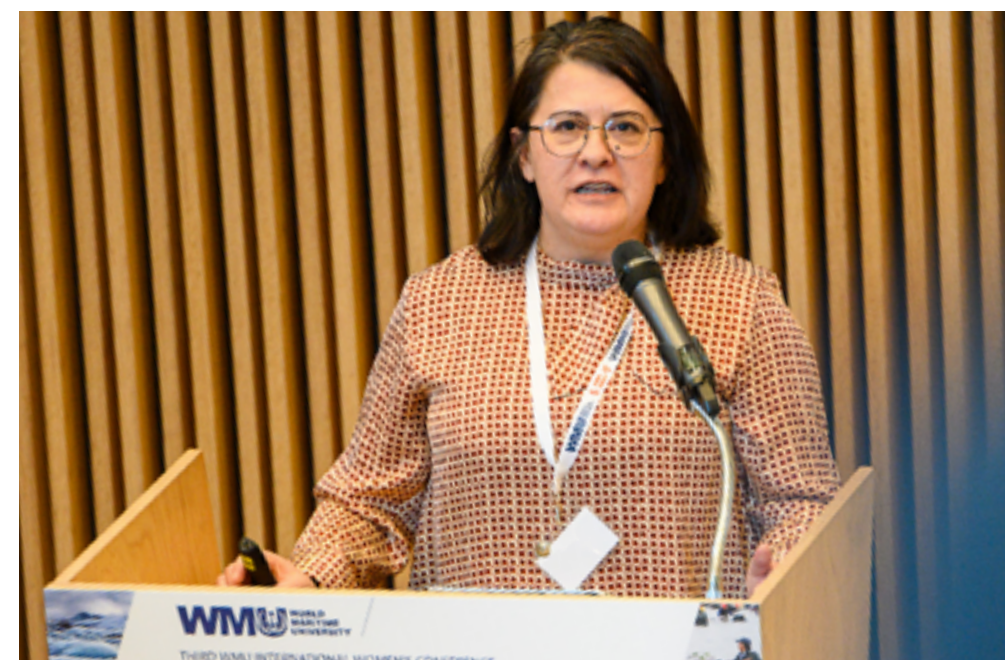

Ms. Jacqueline Smith, Maritime Coordinator, ITF, recalled her election as the first female President of the Norwegian Seafarers' Union and as the first non-100 per cent Norwegian. The event was featured in the newspapers at the time, which made her male colleague comment, "I don't really understand why you are featured in the newspapers, because we didn't elect you because you're a woman. We elected you because you are the best person for the job." Jacqueline emphasized that:

\section{"WE WANT TO GET WHERE WE ARE BASED ON MERIT. BUT, OF COURSE, WE NEED TO BE GIVEN AN OPPORTUNITY, AND PEOPLE NEED TO SEE THE MERIT THAT WE HAVE AS A WOMAN."}

Ms. Smith also stressed the fact that women are transformational leaders who often motivate and bring the team along, while men are mostly transactional leaders - a dominant type of leadership. Having both types of leaders is a necessity in today's society, which the speaker characterised as an extraordinary time of extremism and racism from her unionist perspective. When countries are closing their borders to the most vulnerable and leaders are talking about building walls to keep people out, believing in our gender and ethnic diversity makes us a target in today's society.

After all the challenges and wars, women and men came together and supported each other by showing compassion. Women are not unfamiliar with the fact that we face sexism, ageism, discrimination and harassment, but we have learnt how to be calm, find our voice, speak up and change our narratives. Women do this, not just for themselves but also for everyone, because women are compassionate people. Ms. Smith concluded her speech with a powerful message: "Be YOURSELF! Put your footprints on it. Support and mentor women coming up alongside you, standing with you and behind you. You have to speak up and act for those who do not have a voice, and you can help them find that voice." 
The next speaker, Ms. Maja Markovčić Kostelac, Executive Director of EMSA, began her speech by stating how proud she is of being a woman and a maritime professional. Ms. Kostelac appealed to young people:

\section{"CHOOSE THE MARITIME PROFESSION. SHIPPING IS COOL!" \\ MS. MAJA MARKOVČIĆ KOSTELAC}

According to EMSA, women seafarers account for only 2.2 per cent (27,200 individuals) compared to 97.8 per cent of males $(1,200,000$ individuals). The majority of women seafarers (94 per cent) work on cruise ships and passenger ferries while the others (6 per cent) are employed on cargo ships. The speaker analysed the causes as to why women seafarers are so few in number, and listed their challenges, such as gender prejudices, the working and living conditions, legal and administrative obstacles, work-family reconciliation issues, physically demanding tasks, unequal pay, lack of information and opportunities and the glass ceiling.

However, the paradox in shipping is a lack of maritime professionals. The BIMCO and ICS reports currently estimate a shortage of 60,000 personnel, which will reach an even higher shortage of 147,000 individuals by 2025 . Ms. Kostelac thinks that this is an opportunity for shipping companies because it has been proven that a multigender working environment creates a safer, more efficient and stable company. A balanced approach is necessary, but a single channel cannot address each challenge; therefore it is an issue for everyone to address and solve, including administrations, industries, conference participants and other stakeholders within their responsibilities and capacities.

In the case of EMSA, with the Declaration on Equal Opportunities, their policy on gender balance includes promotion of values of non-discrimination by gender, equal opportunities in attracting and recruiting staff and the retention of women. Approximately 35 per cent of EMSA's employees are women; 40 per cent are in management positions and 97 women employees are ex-seafarers.

Ms. Nancy Wakarima Karigithu serves as Principal Secretary, State Department for Shipping and Maritime, Ministry of Transport, Infrastructure, Housing and Urban Development and Public Works, Nairobi, Kenya. Ms. Karigithu found that the IMO programme on Integration of Women in the Maritime Sector (IWMS) was very helpful in building an institutional framework for empowering women professionals, including herself. In developing countries, it enabled better access to training and employment opportunities for women. In 1994, Nancy graduated from the International Maritime Law Institute (IMLI) where the IMO programme has ensured that 50 per cent of enrolment is female. Such training opportunities help the industry because shipping is competing with other industries to seek the most talented and bright young people. It is time for the shipping industry to build a brand of an exciting industry with many cool jobs.

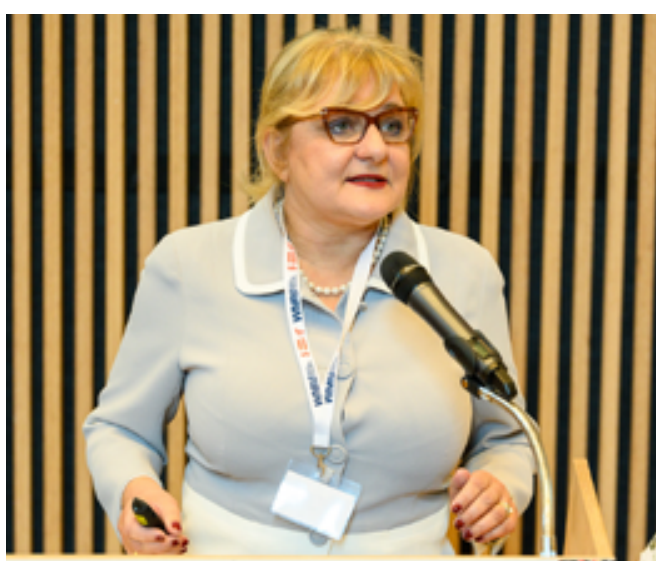

. 


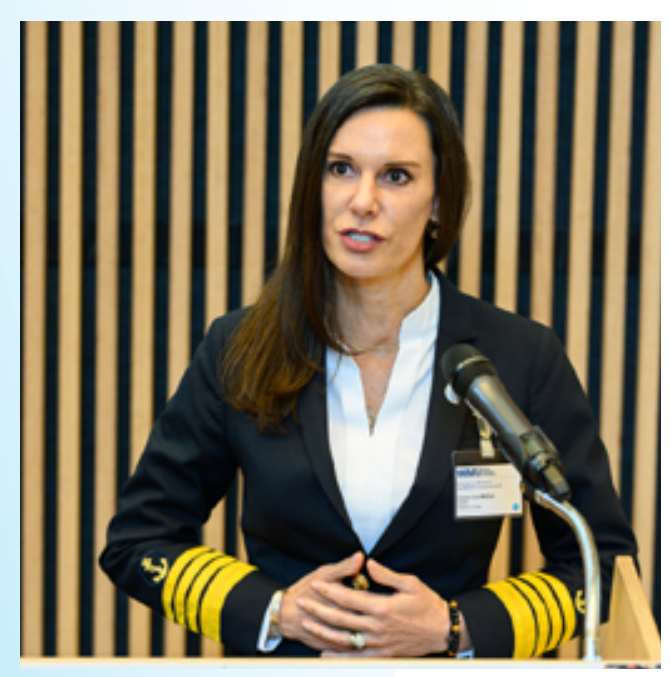

"THE SECRET OF MY SUCCESS IS THE COMPANY I KEEP AND THE PEOPLE WHO SURROUND ME THE DIVERSITY. IT'S NOT HAVING ALL WOMEN. IT'S NOT HAVING ALL MEN. IT'S THAT DIVERSITY THAT ACTUALLY BRINGS OUT THE BEST IN EVERYBODY."

CAPT. KATE McCUE
Gender diversity is important because it brings the skills that move industries forward. In order to cope with digitization challenges, maritime employment should seek strong minds. As women, we must keep knocking on the doors and when the door closes today, keep pushing again.

Captain Kate McCue, Celebrity Cruises, was the final speaker on the panel. She shared her own story to emphasize the positive side of being a woman seafarer. Her parents took her and her brother on their first cruise when she was 12. The experience inspired little Kate and she told her father that she wanted to be a cruise director. However, her father said to her, "You can do anything you want in the world, including drive the thing." Her father, who was unable to attend a maritime academy himself, due to the age restriction, reminded her about that conversation when she was deciding on her education path. After graduating from the California Maritime Academy, she started to apply to all the cruise companies. She waited and waited and continued to send resumes, but did not receive a response for 18 months.

She then changed her resume to apply for a bartender position on Disney Cruise Line. The HR department noticed that she was not qualified to be a bartender, but rather to be a deck officer. Eventually, she moved to Royal Caribbean Cruises and was promoted to 2nd Officer. After 13 years at Royal Caribbean, the new CEO of Celebrity Cruises, Ms. Lisa Lutoff-Perlo, promoted her to be the first American female cruise ship captain in history. Captain McCue was amazed by the corporate culture of Celebrity Cruises, which is very open. They were happy to discuss new ideas with her, such as making a tie (symbolic of male attire) optional, and reviewing the design of belt loops and pockets in pants.

Reflecting on the many positive experiences she has had throughout her career, Captain McCue concluded that diversity helps women achieve success, stating: "The ship that I am on right now has 1,240 crew members from 72 different nationalities, all under one roof. The reality is that we are all minorities of race, religion, cultural background and sexual orientation. Whatever it is, it puts us on the same levelplaying field. We don't point to differences with each other. In fact, we celebrate them."

Captain McCue is using her Instagram to show the life of a captain and her cat - an inside-look to appeal to young people and show them that shipping is cool and glamorous. Using social media platforms is one of the ways to tell the world what incredible opportunities shipping can offer. 

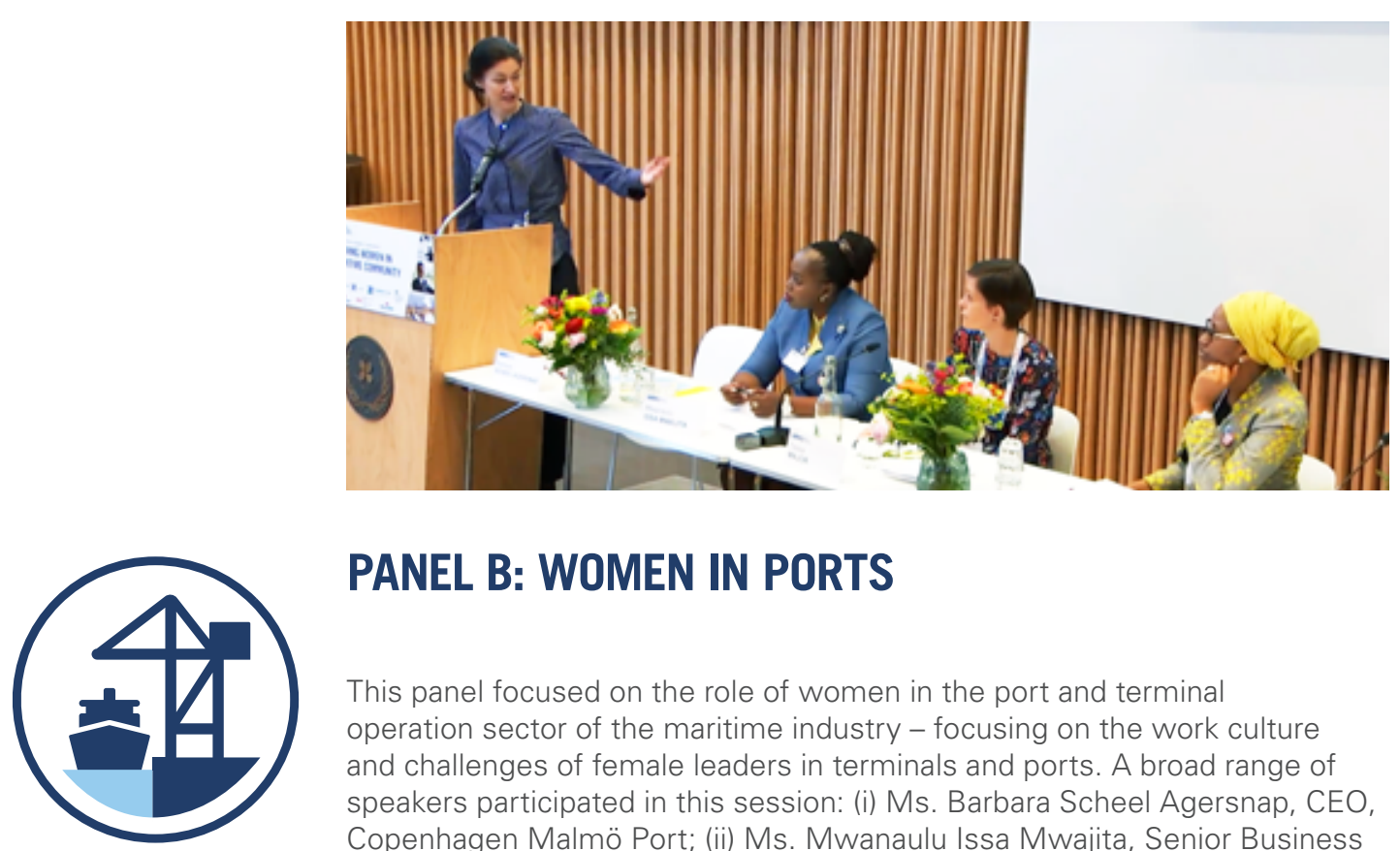

PANEL B: WOMEN IN PORTS

This panel focused on the role of women in the port and terminal operation sector of the maritime industry - focusing on the work culture and challenges of female leaders in terminals and ports. A broad range of speakers participated in this session: (i) Ms. Barbara Scheel Agersnap, CEO, Copenhagen Malmö Port; (ii) Ms. Mwanaulu Issa Mwajita, Senior Business Analyst Kenya Trade Network Agency; (iii) Ms.Tessa Major, Commercial Director, Portodo Açuin Brazil; and (iv) Ms. Hadiza Bala Usman, Managing Director, Nigerian Ports Authority.

Speakers not only shared their views about the challenges they faced in various work environments because of their gender (as the maritime sphere was traditionally, and still is, a male-dominated industry), but also how they excelled in their respective careers despite numerous hindrances obstructing their growth. Biases towards women in the maritime industry are still the major barrier for gender equality in shipping and ports. To develop an effective and sustainable work environment at ports and terminals, it is important not only to have a gender balance but also to promote equality and zero tolerance to harassment and bullying within the port company/organization. This panel was moderated by Ms. Barbara Scheel Agersnap, CEO, Copenhagen Malmö Port (CMP).

While introducing the panel members, Ms. Angersnap mentioned that Copenhagen Malmö Port does its best to have a gender balance, although it is always very difficult to maintain an absolute balance. While only 17 per cent of Copenhagen Malmö Port employees are women, almost 50 per cent of the management level employees are women - which is quite comforting for her.

\section{Panel B: Critical Takeaways and Policy Relevant Highlights}

- Men alone are expected to fill some jobs, which creates additional challenges for women.

- Health and educational attainment are often considered a closed gender gap, while political empowerment and economic participation and opportunities are not. Other reasons as to why there are fewer women in the maritime industry include social and cultural expectations, work-life balance and lack of awareness.

- Even with the higher representation of women, most women are still at the entry-level and cannot move up the ladder. 


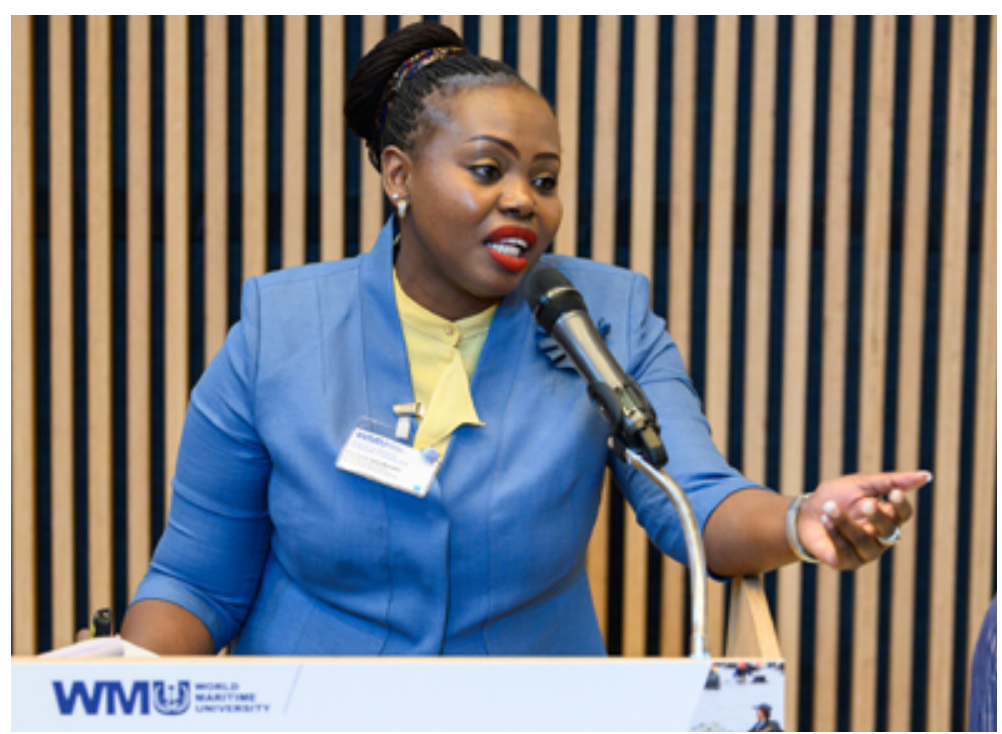

\section{"MOST OF THE TIME - I AM THE ONLY WOMAN WORKING IN MY DEPARTMENT. HOWEVER, IT IS ALSO INTERESTING TO OBSERVE THAT - IF A WOMAN LEADS THE PROJECT FOR TECHNOLOGICAL DEVELOPMENT, AT FIRST THE AUDIENCE IS SURPRISED BUT THEN THE AUDIENCE ACKNOWLEDGES AND ACCEPTS THIS IN UNBIASED APPRECIATION".}

MS. MWANAULU ISSA MWAJITA

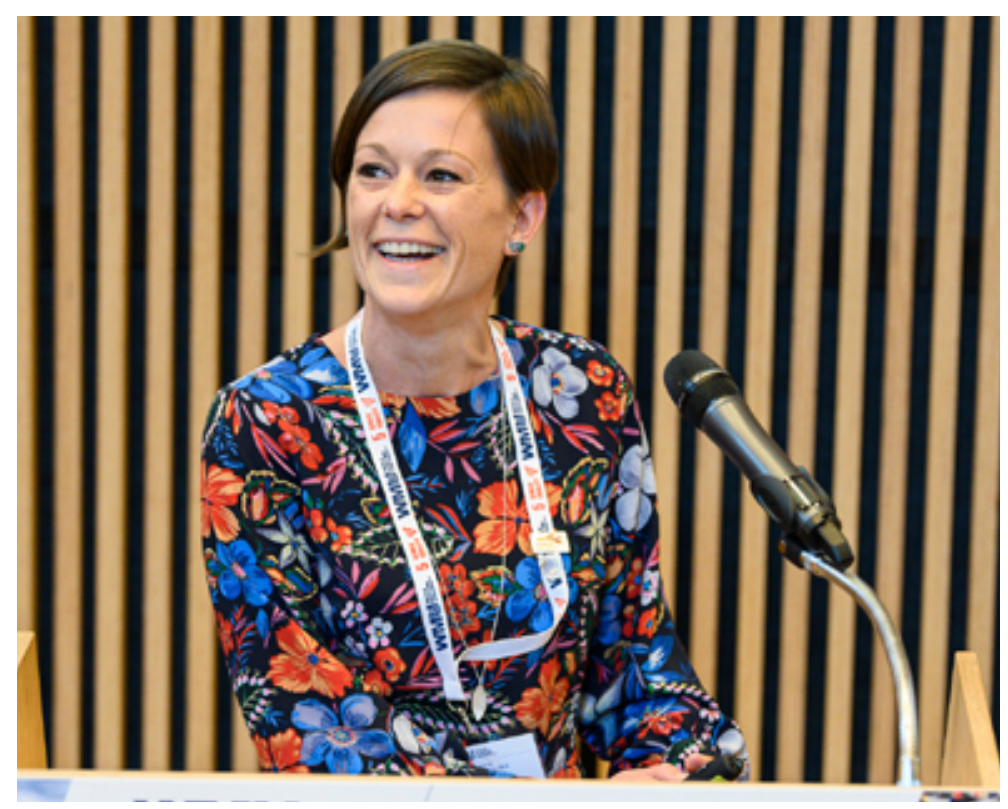

Ms. Mwanaulu Issa Mwajita, Senior

Business Analyst, Kenya Trade Network Agency, works in terminal and port operations, working closely to develop the single window system integrating various export/import departments in Kenya. She strongly believes that innovation is the way forward, including the use of artificial intelligence and machine learning where machines talk to each other and perform their operations effectively. She also emphasized that women working for port operations from engineering and technology expertise are very limited.

She explained the reasons for the lack of gender balance in this sector which are mainly due to: (i) social and cultural obstacles - this is considered as a traditional career reserved for men; (ii) lack of equal opportunities and training - many companies are unwilling to hire female automation professionals as it is perceived that men are good with technology; (iii) work-life balance - which is mainly juggling professional and personal life and hence a strong support from family is required; and (iv) lack of awareness as maritime ports and automation are such a niche sector, which means not many are aware of various growth opportunities there.

Education, policies and leadership commitment are the main three important pillars to progress in establishing gender balance. Information is powerful, and hence social media should be used to campaign and bring awareness to join the maritime and port industry.

Ms. Tessa Major, Commercial Director, Portodo Açuin Brazil, gave a brief background of the business conducted at Portodo Açuin. Ms. Major is actively developing the port and by 2021, the port will be able to cater to 70 per cent of Brazil's oil and energy demand. It is not only in ports, but also in the whole of Brazil that a gender imbalance exists. For example, presently, only 9 per cent of the ministers in Brazil are women and this is true for most of the BRIC countries. In Portodo Açuin, 30 per cent of the employees are women and only 12 per cent of leadership positions are held by women.

Ms. Major presented a plan to address and resolve gender imbalance issues in the port. This involves answering the questions: (i) What should we do as women? (ii) What should we do together? and, most importantly, (iii) What should we expect from men? Portodo Açuin follows a policy of inclusion irrespective of gender and encourages people to ask questions.

It is important to have an inclusive policy. The speaker strongly believes that diversity makes us better and combining different points of view is positive. 


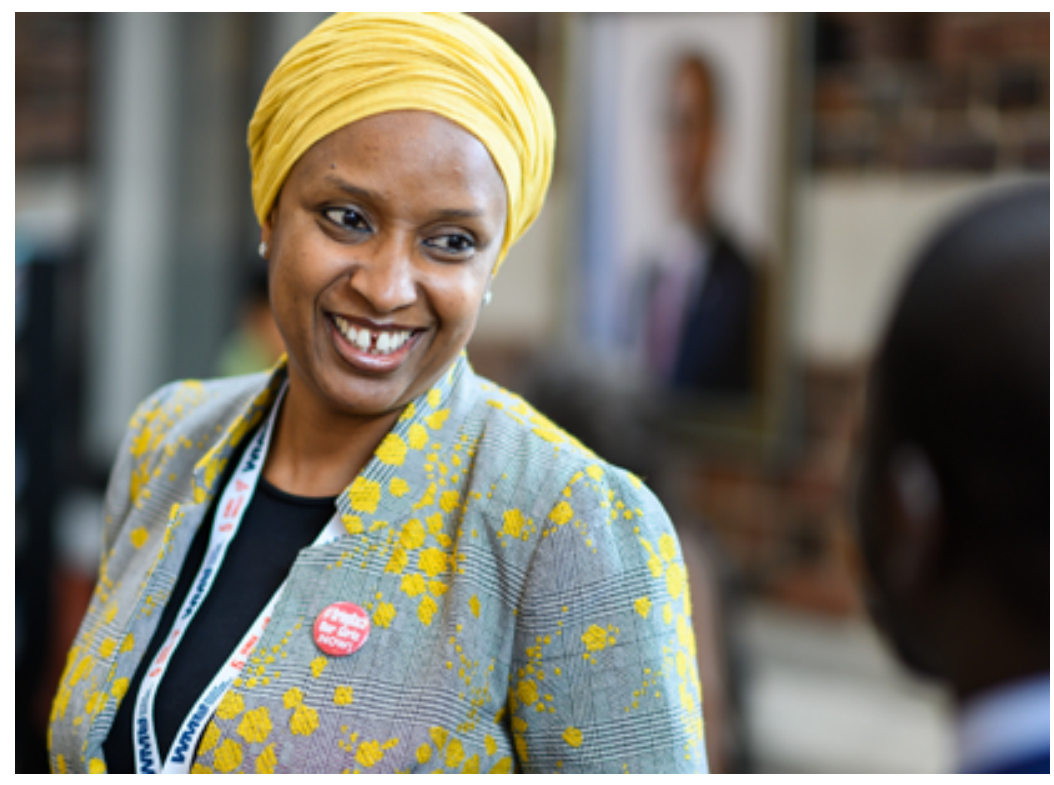

Ms. Hadiza Bala Usman, Managing Director of Nigerian Ports Authority indicated that only 39.3 per cent of the world's labour force is made up of women, as per data released by the World Bank. This statistic indicates that we require change in terms of achieving gender balance across all sectors. In the maritime sector we have even more challenges and most people, especially younger women, are unaware that maritime and ports are like any other careers that they can pursue and be successful at.

Ms. Usman is the first female Managing Director of the Nigerian Port Authority and, of course, a role model for young women wishing to pursue maritime as a career whether in port and terminal operations, seafaring, maritime technology, or project management, among others. The maritime sector is like any other corporate sector with its own unique characteristics, which can be fun and add flavour to one's life.

In Nigerian ports, only 23 per cent of the employees are women and most are at the entry position and at the mid-management level. Most women leave their jobs to take care of their family. We should support and encourage women to continue their professional careers to maintain a social balance, not only in the maritime and port sector, but beyond.
"I URGE EVERY ONE OF US TO BE AMBASSADORS FOR THE MARITIME INDUSTRY TO ENCOURAGE THE YOUNG GENERATION, BOTH MEN AND WOMEN, TO JOIN THIS SECTOR AS WE NEED MORE PEOPLE TO LOOK AT MARITIME AS A FUN INDUSTRY TO WORK IN."

MS. HADIZA BALA USMAN

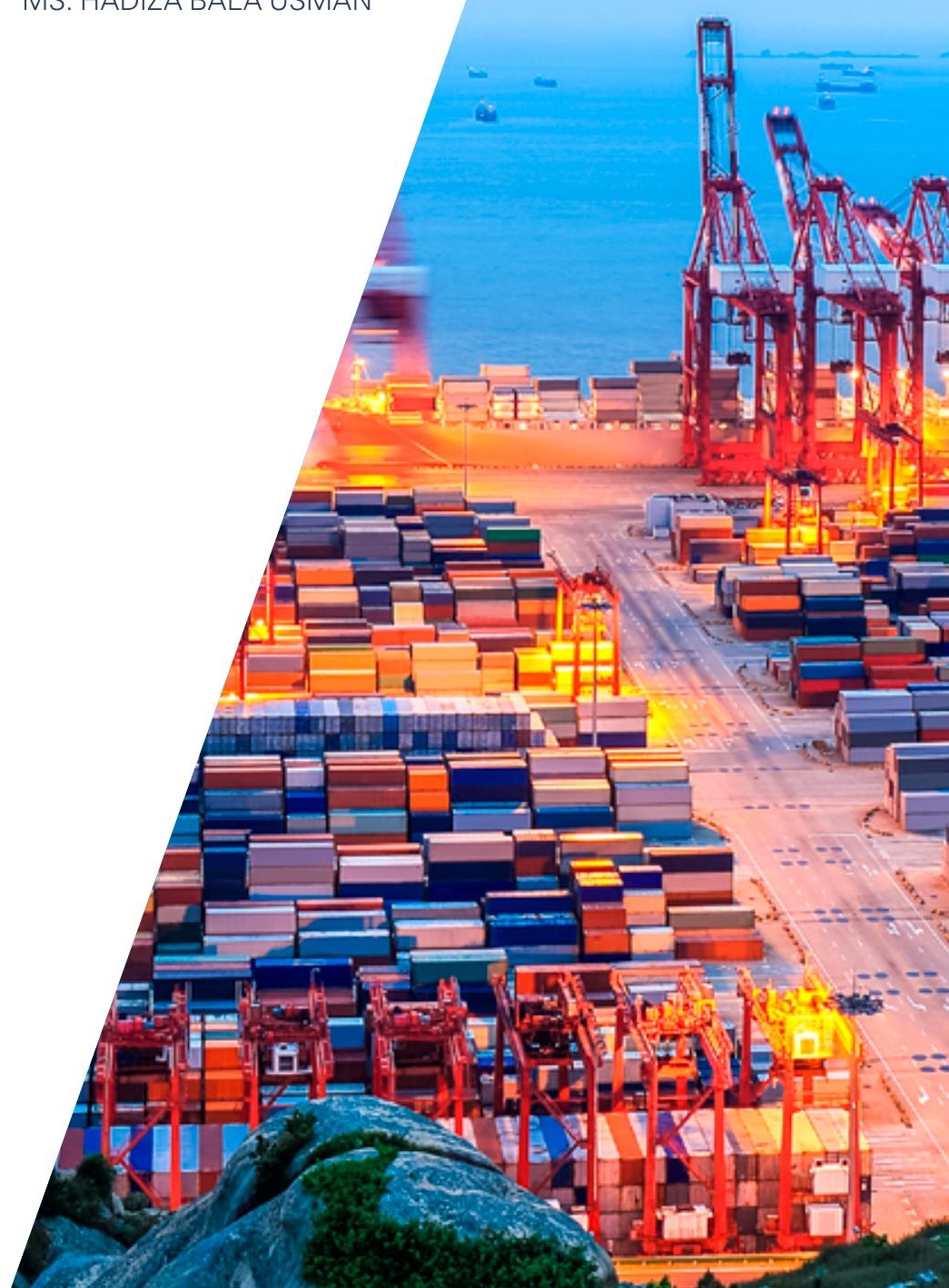




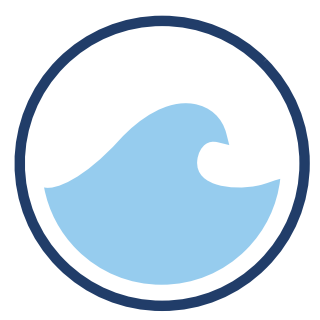

\section{PANEL C: WOMEN IN OCEAN AND MARINE SCIENCE}

This panel focused on the role of gender equity, gender-balance, and inclusion for greening the blue economy. Ms. Helen Ågren, Swedish Ambassador for the Ocean, Government of Sweden, moderated this panel. The panellists were women from varying career levels that are proactively engaged in ocean and marine science activities.

\section{Panel C: Critical Takeaways and Policy Relevant Highlights}

- The number of role models is increasing, but many people are still comfortable with the status quo, which must change.

- Better inclusion and gender equality will lead to better development results.

- Science and governmental policy and action should be linked to promote gender equality across all spheres of work.
- Women should be supported to express and support advocacy, innovation, business, research agendas, and more attention should be paid to women in ocean governance, including justice.

- Gender equality should be integrated as a given process in sustainable ocean management.

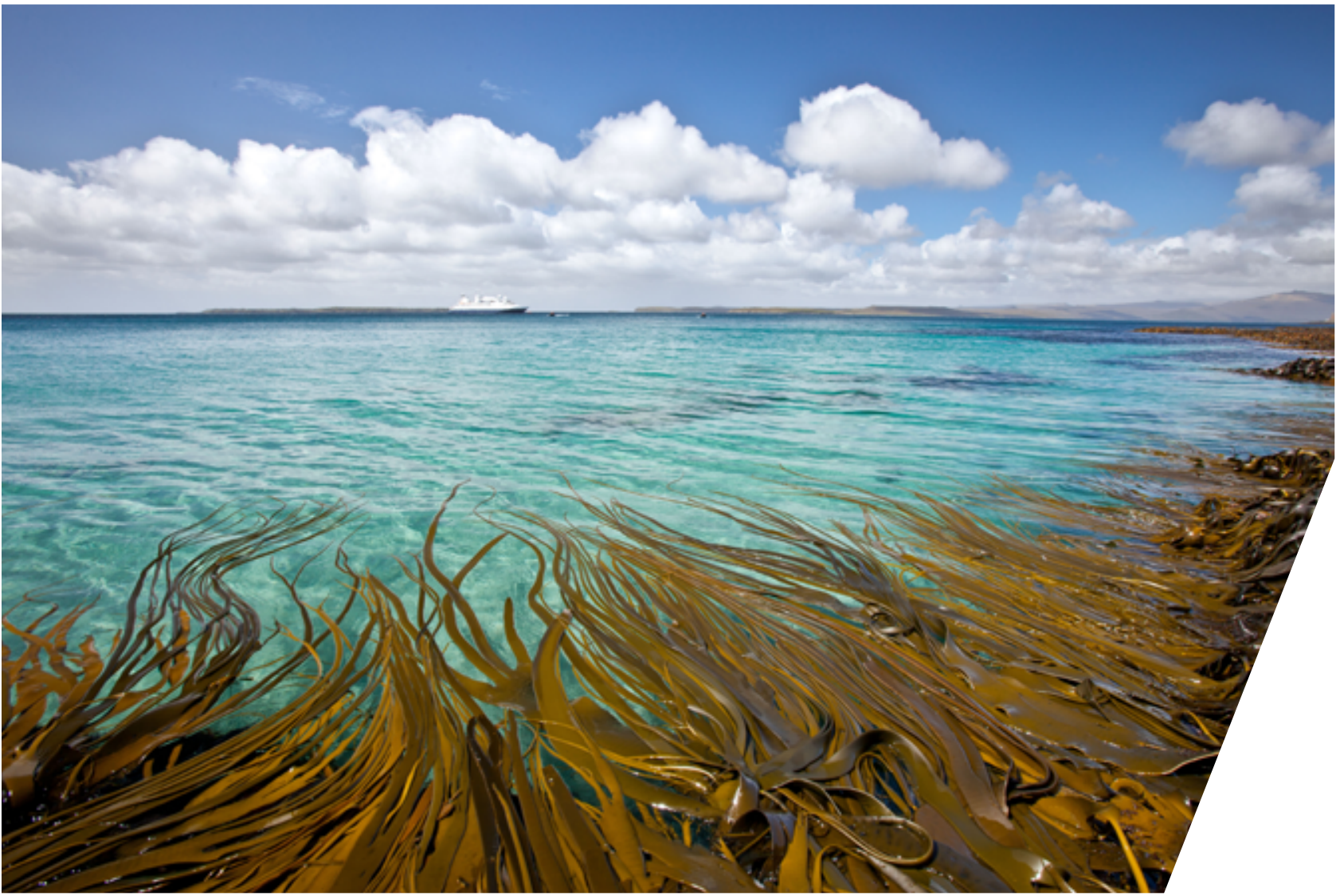




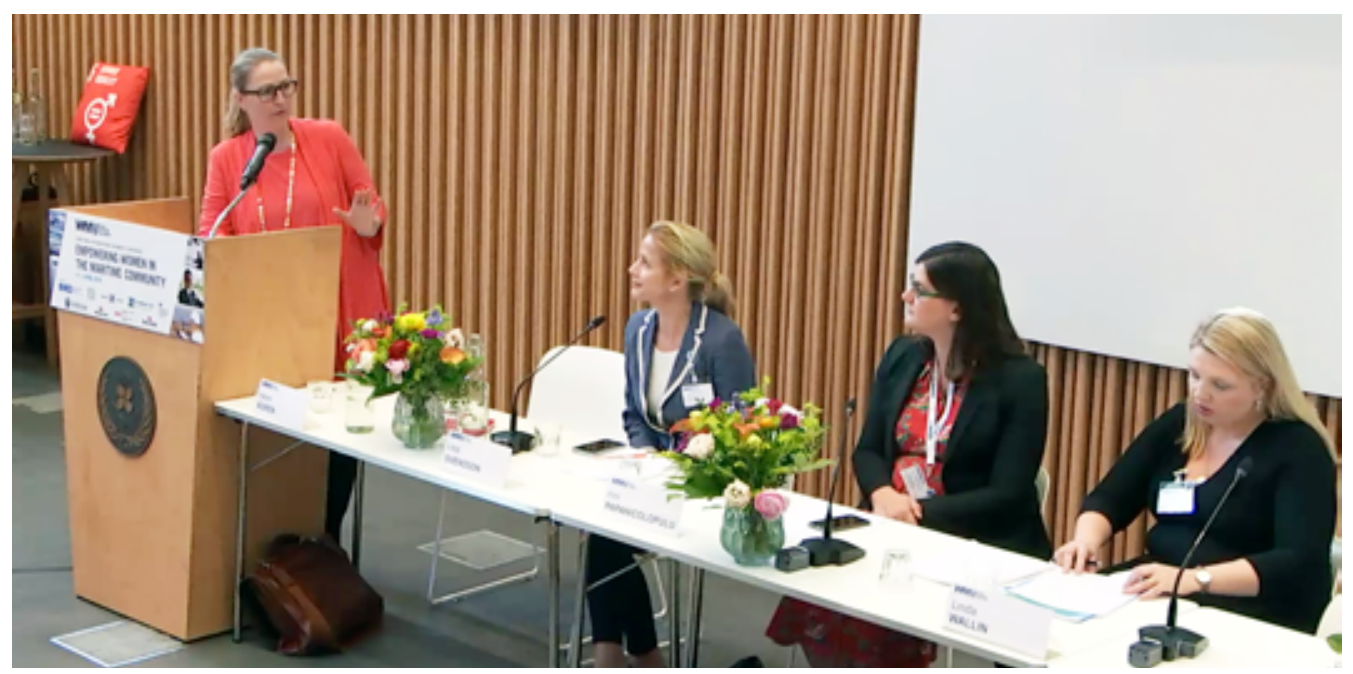

Ms. Helen Ågren opened the panel discussion by sharing her view on the Swedish Government's approach on the gender issue, which includes setting SDGs 5 and 14 very high on its agenda. The Swedish Government also has many distinguished women occupying high government positions, including the Minister for Foreign Affairs, Ms. Margot Wallström, who launched the world's first feminist foreign policy, and Dr. Isabella Lövin, Minister for Environment and Climate and Deputy Prime Minister, who led the arrangements for the first United Nations Ocean Conference.

Ms. Lisa Emelia Svensson, formerly Marine and Coastal Ecosystems Branch, United Nations Environment, served as a professional diplomat with the Swedish Government in various positions for many years, including as the former Ambassador for the Ocean. As her own experience demonstrated, in earlier years Sweden faced a number of issues when it came to recruiting women, particularly for higher positions, as the workforce was traditionally male-dominated.

The situation of gender imbalance is still quite serious globally. Ms. Svensson called on all stakeholders to make changes. Firstly, she pointed out that technological development, particularly social media, could play an important role in raising awareness of gender imbalances in all fields and at all levels. Secondly, she emphasized that efforts needed to be made to break the male gender driven network and forum that usually excludes women from participation. Thirdly, Ms. Svensson pointed out that women and gender issues needed a more flexible work-life approach in the ocean field, and a flexible approach should be adopted that emphasized moving away from the rigid system in which everyone works in the same place with fixed hours. Fourthly, Ms. Svensson echoed the previous speakers, emphasizing the importance of women putting themselves forward for opportunities and expressing their opinions. Biases, however, still exist in the workplace when women speak up. This is a situation that needs to be addressed when it occurs.

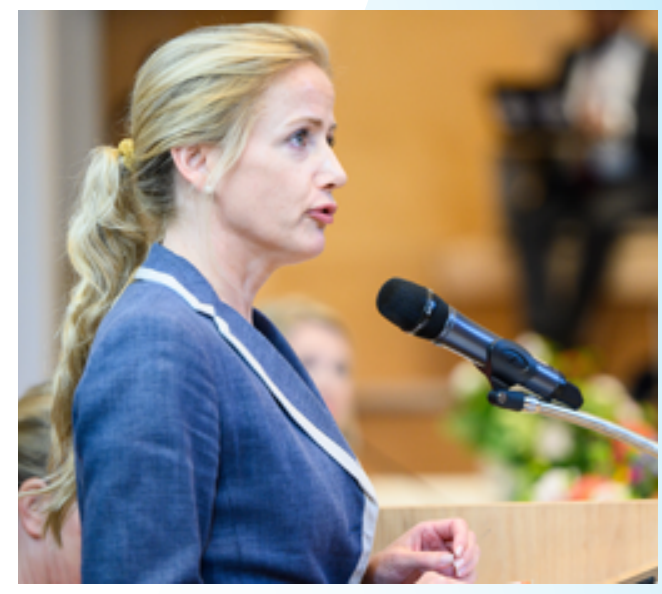

"GENDER IS ABOUT INCLUSIVENESS,
... IT IS ABOUT ALL PEOPLE NO
MATTER THE CULTURE OR COLOUR."

MS. LISA EMELIA SVENSSON 


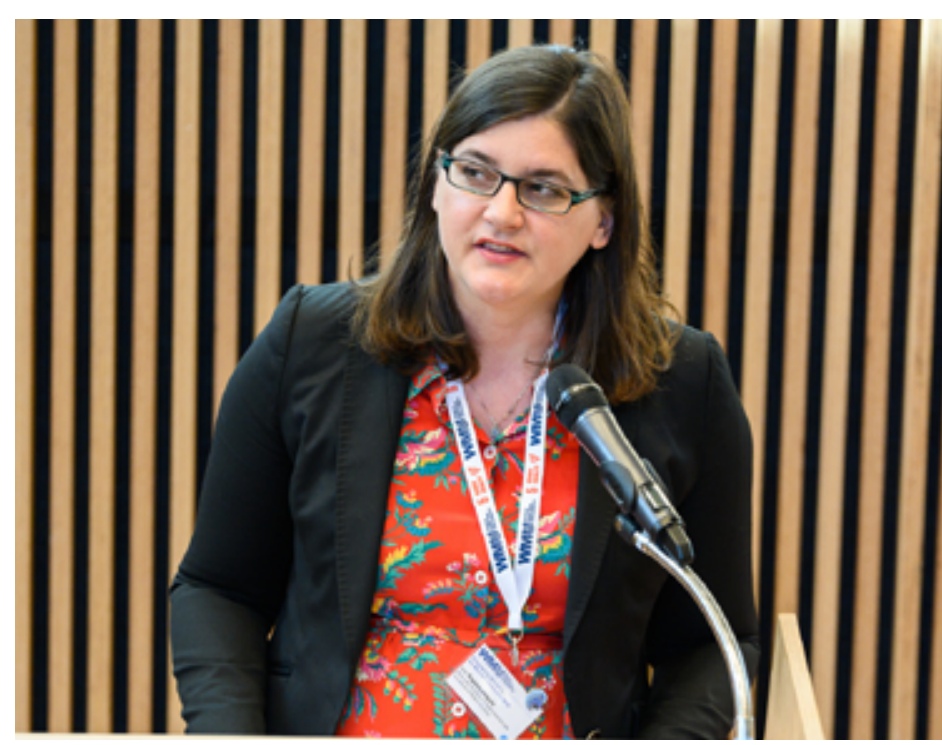

“GENDER INEQUALITY AND THE TRADITIONAL PATTERN OF BEHAVIOUR BETWEEN MEN AND WOMEN ARE NOT ONLY HURTING WOMEN, THEY ARE ALSO HURTING MEN."

DR. IRINI PAPANICOLOPULU

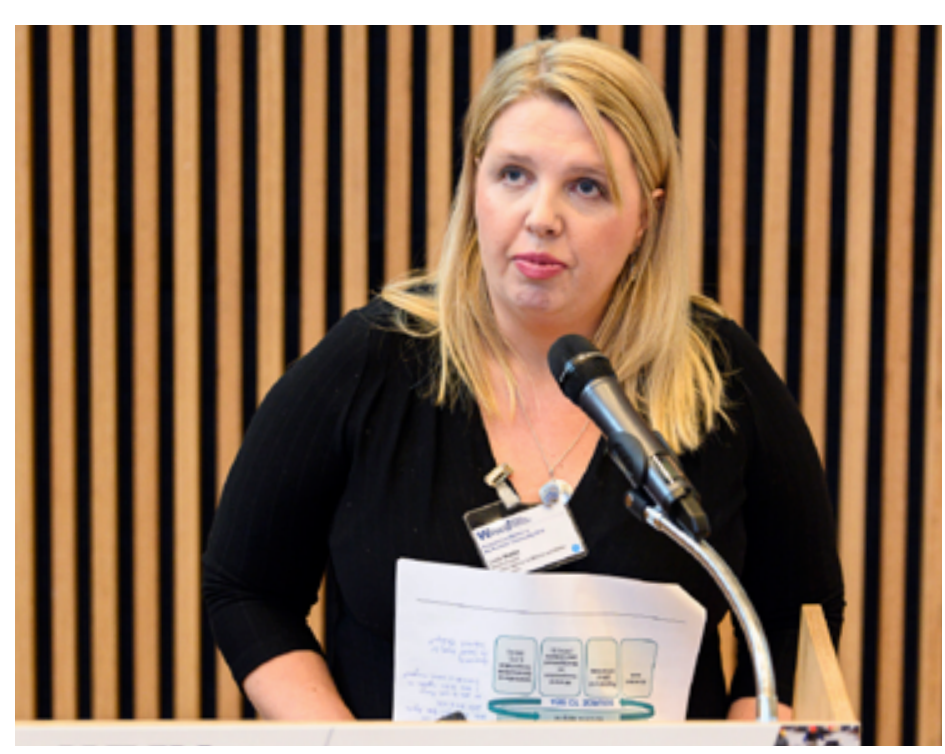

Dr. Irini Papanicolopulu, Associate Professor of International Law, Università di MilanoBicocca, has a diverse background in academic, government and the private sector. The law of the sea is traditionally a male-dominated field, especially for subjects such as delimitation of maritime boundaries. Speaking from personal experience, Dr. Papanicolopulu found herself supported by her male colleagues, although she also came across gender biases in her professional work.

Dr. Papanicolopulu has edited a book, Gender and the Law of the Sea (Brill 2019), in which the authors discussed the obstacles and ways forward for women to do research in the law of the sea. She emphasized that we should not view ocean research as static and must promote interdisciplinary research across law and marine science. On the obstacles preventing women from conducting marine science research, she referred to the lack of information and knowledge of the ocean and science in general; the scarcity of female leaders who could serve as role models for younger women; the general lack of interest in encouraging women to conduct ocean research; and the absence of sufficient opportunities for women.

Dr. Papanicolopulu also spoke of the importance of changing deeply entrenched biases and the mentality of women when they think that law of the sea is not interesting, and of men when they think that women can only work on human rights and environmental issues.

Ms. Linda Wallin, Senior Analyst, International Affairs, Science Affairs Department, Swedish Agency for Marine and Water Management (SwAM), shared the perspective of a national agency. Ms Wallin spoke of the approach to gender equality in the agency's national work and international development cooperation, and how to link gender equality with sustainable ocean management and ocean science. She stated that for a long time the Swedish public administration has been using gender mainstreaming as a major approach to dismantle inequality and reach gender balance goals in all spheres of work and life.

Ms. Wallin gave a number of examples of the work of Swedish local management agencies where a gender balanced decision-making body resulted in a more diverse, inclusive and sustainable water agenda. However, even within the Swedish Government system, gender inequality cases still arise. 
On SwAM's work in international development cooperation, Ms.

Wallin referred to the important roles men and women play in a range of areas, including economic, environmental and social roles in ocean management, particularly in poor coastal zones. She indicated that women are often excluded from management positions in powerful ocean industries and governance structures due to visible and invisible social barriers, including lack of educational opportunities. She indicated that:

\section{“EXPERIENCE SHOWS THAT WHEN EQUALITY AND INCLUSION ARE THOROUGHLY ADDRESSED IN NATIONAL POLICIES AND STRATEGIES AND ALSO IN COMMUNITY- LEVEL ACTIVITIES, WE GET BETTER DEVELOPMENT RESULTS." \\ MS. LINDA WALLIN}

On the role of gender equality in ocean science, Ms. Wallin echoes other speakers that the role of women is often overlooked. Female scientists can be role models and agents of change, particularly in developing countries. She emphasised that government agencies have a special task to link science and governmental policy and action to promote gender equality across all areas of work.

Ms. Wallin referred to a new programme to be launched at SwAM: SwAM's International Development Cooperation Programme 20192022 - SwAM OCEAN. The new programme contains a gender equality approach and specific gender equality goals, including strengthening women's economic rights in ocean and fisheries management, and the strengthening of women's participation and influence in ocean and fishery management decision-making. SwAM OCEAN will include gender studies in marine spatial planning, marine protected areas management, trade in fisheries service and smallscale fisheries in the least developed countries and small island developing States.

Looking forward, Ms. Wallin identified several areas where more attention is needed. These include supporting women as researchers, knowledge-holders, producers and entrepreneurs in ocean science and the blue economy; supporting women in expressing and producing their own research agendas, innovations, and businesses; promoting women in ocean governance, including justice; strengthening a rights-based approach to women's participation; mainstreaming gender as an important process in sustainable ocean management; and forming stronger partnerships between government agencies and science communities for gender equality. 

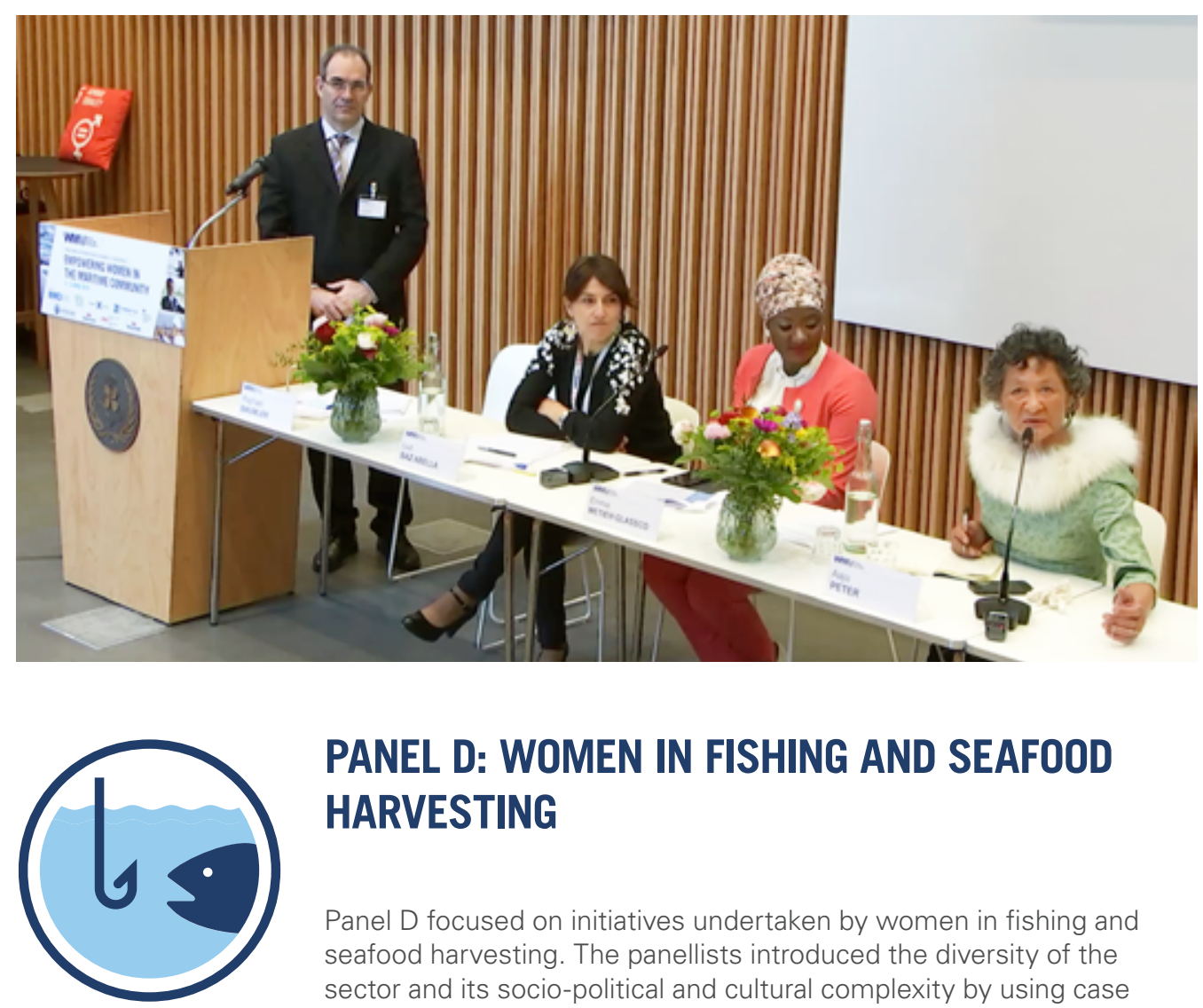

\section{PANEL D: WOMEN IN FISHING AND SEAFOOD HARVESTING}

Panel D focused on initiatives undertaken by women in fishing and seafood harvesting. The panellists introduced the diversity of the sector and its socio-political and cultural complexity by using case studies. Speakers recalled how fishing, a tradition that has existed down the centuries, remains anchored in society. The panel confirmed the importance of the balance needed between women and men in the sector despite a visible gender distribution of tasks. The panellists shared their unique experience on topics such as administration, management, fishers' support and the challenges facing traditional communities. Associate Professor Raphaël Baumler of WMU moderated this panel.

\section{Panel D: Critical Takeaways and Policy Relevant Highlights:}

- Fishing cannot be reduced to an economic activity. - Empowering women in the fishing sector requires It also has deep cultural and social dimensions, including for indigenous peoples.

- While women are underrepresented on fishing vessels, their contributions are vital to postharvesting activities and aquaculture.

- Making women visible and recognizing their role is vital to enhancing their condition. action to be taken at the national, regional and global levels.

- National laws and regulations should support women and propose solutions to facilitate their social promotion.

- Indigenous communities are ocean-dependent for their survival and must be consulted on issues and decisions which may affect their livelihoods. 
Ms. Luz Baz Abella, inspector and national coordinator of the International Transport Workers Federation (ITF) in Vigo, Spain), and an active member of WISTA, was initially trained as a deck officer. Later, she studied law and joined the bar association in Spain and the ITF. Ms. Baz Abella highlighted the importance of cooperation between women and men in the workplace. She referred to the origin and role of the ITF which currently represents 19 million workers from 150 countries. The ITF supports decent working and living conditions and promotes safety at sea. Inspections and collective bargaining agreements are key tools for the ITF in its support of fishers and seafarers. Emphasizing the dangerous nature and harsh conditions on board fishing vessels, she referred to the lack of ratification, implementation and enforcement of international instruments relating to safety and social conditions, particularly compared to seafaring. Ms. Baz Abella underlined the negative social impacts of illegal, unreported and unregulated (IUU) fishing. She also focused on women in the fishing and seafood harvesting sector in Spain. Despite the relative absence of women on fishing vessels (less than 5 per cent), the role of women remains vital in shellfish gathering and aquaculture (70 per cent), in the processing industry (62 per cent) and in marketing (53 per cent). Ms. Baz Abella also referred to the role of women in supporting fishing communities and families. She presented a Spanish initiative: The Spanish network of women in the fishing sector. This tool has made women's contribution more visible, promotes their participation and empowers and assists them.

Ms. Baz Abella emphasized:

\section{"NO SUSTAINABLE DEVELOPMENT OF THE SECTOR CAN BE ACHIEVED WITHOUT RECOGNIZING THE} ESSENTIAL INPUT OF WOMEN.“

\section{MS. LUZ BAZ ABELLA}

WMU graduate, Ms. Emma C. Glassco is the first female Director General of the National Fisheries and Aquaculture Authority in Liberia. She recalled the participation of women in Liberia's history. Liberia elected the first female president in Africa, Ms. Ellen Johnson Sirleaf, and currently has a woman Vice-President, Ms. Jewel Howard-Taylor. She referred to the evolution of the fishing sector from a subsistence and traditional practice to an industrial activity imbedded in global trade. She described the various harvesting techniques, and explained the male domination in fishing vessel operations. Women's presence is primarily in post-capture activities onshore, such as processing and preservation, marketing and distribution, as well as making and mending equipment.

However, women are also associated with fishing in coastal areas and inland waters using traditional nets and baskets. Unfortunately, these activities remain poorly recognized and valued despite their importance in sustaining food security and family income. Women represent 47 per cent of the fisheries and aquaculture workforce and 70 per cent of them are engaged in fish farming. In Liberia, women account for 60 per cent of the sectoral workforce but remain confined to low-income activities. Ms. Glascco noted that the intake of fish protein in the Liberian diet is insufficient because the country does not supply sufficient quantities to the local market. The lack of amenities to preserve fish also results in large post-harvesting losses.
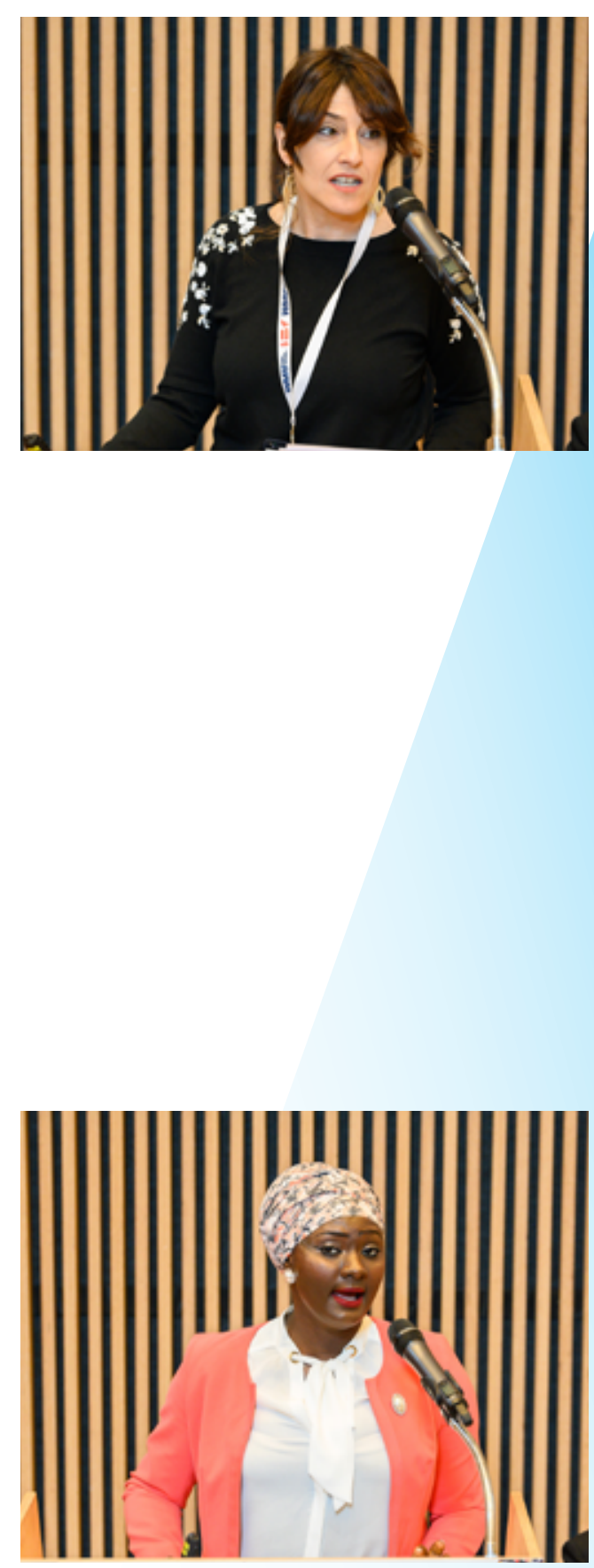
The Liberian Government intends to protect the rights of fishmongers by developing policies and offering micro-loans solutions to support small-scale traders who are mostly low-paid women affected by the competition of imported seafood.

She also stressed the importance of multinational partnerships between developed and developing countries with strong fishing expertise. In order to empower women in fishing, Ms. Glassco recommended a multi-layer approach with three levels: global (participation, training, access to capital and distant markets), regional (knowledge transfer and education) and national (policy and initiatives for women in fishing and maritime). She concluded with these words:

\title{
“I BELIEVE A WOMAN'S GREATEST ASSET IS TO BELIEVE IN HERSELF AND KNOWING THAT SHE HAS THE POWER TO CHANGE HER ENVIRONMENT."
}

\author{
MS. EMMA C. GLASSCO
}

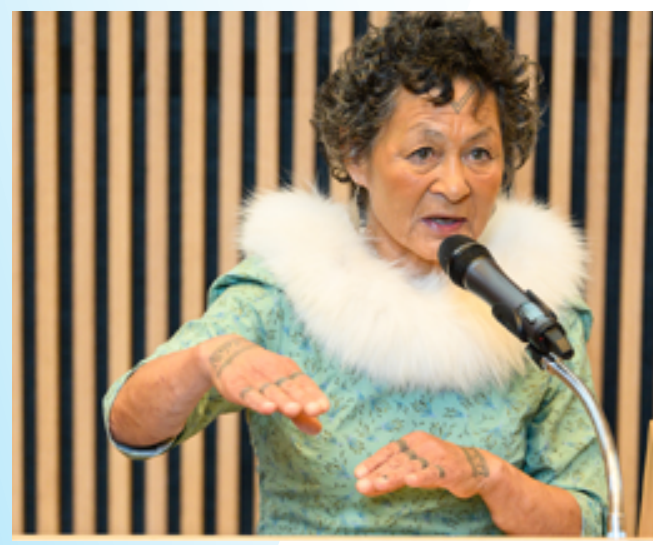

Ms. Aaju Peter is a lawyer, translator and Inuit cultural advocate, representing Nunavut, Canada, and the Greenlandic Iqaluit. She began her presentation by a traditional song. The emotions transmitted by the song were a reminder of the importance of culture in fishing activities, particularly for traditional communities. Ms. Peter highlighted the importance of the Arctic environment: snow, sun, sea and isolation. She recalled how the environment influences and shapes social interaction. She emphasized the symbolic and vital importance of the sun (new life) and sea (goddess), revealing that Inuit women have these symbols tattooed on their faces and hands. In a region where food security remains uncertain, sharing food and enjoying the benefits of the 'sea goddess' represents major cultural values and denotes the respect Arctic Natives have for their environment and the ocean.

However, the ancient way of life of the Inuit people has been seriously altered by colonization. Former nomads who followed their game, the Arctic hunters and fishers have been organized into small communities, currently totalling 27 in the Canadian Arctic. The vast Nunavut territory hosts only 38,000 people. Locals have adapted to the environment socially, culturally and economically by developing specific activities.

In that regard, sealing and fishing are essential for food and for economic sustainability. The speaker stressed that the European ban on seal products, decided without consulting affected people, wreaked havoc on the economy of traditional communities. Without possibilities to sell seal products, hunters cannot generate sufficient income to feed their remote communities. In addition, women's activities dependent on seal skin products collapsed, which affected the overall communities' income. In conclusion, she emphasized the importance of consulting the indigenous people when decisions affecting their territory and livelihood are at stake. 

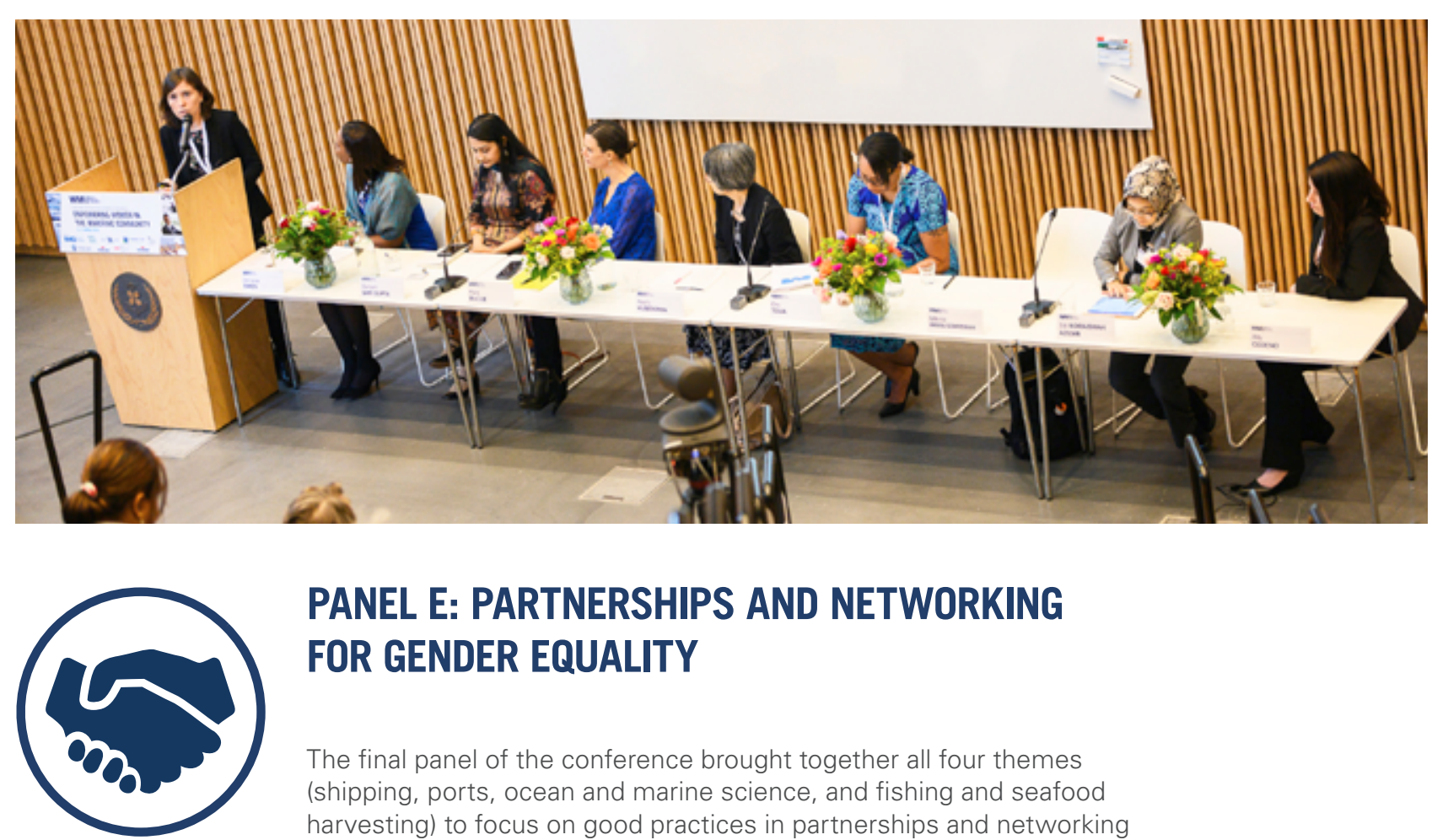

\section{PANEL E: PARTNERSHIPS AND NETWORKING FOR GENDER EQUALITY}

The final panel of the conference brought together all four themes (shipping, ports, ocean and marine science, and fishing and seafood harvesting) to focus on good practices in partnerships and networking toward the achievement of gender equality. The wide range of speakers represented the shipping industry (Sitara Shipping Ltd. and Royal Caribbean Cruises); ports (Sabah Ports Sdn. Bhd); a regional organization (Pacific Community); a research network (Too Big to Ignore Network); and women's organizations (Women for One Ocean; Women Offshore Foundation).
A common message among the speakers was the need to form strong partnerships in order to affect change in the maritime industry. The speakers shared partnership and networking mechanisms from their own organizations and projects and actions that promote women's involvement in the maritime and ocean sector. The panel was moderated by WMU graduate, Ms. Deneice M. Aiken, Vice President of Legal and Maritime Affairs/Executive Director of the Maritime Training Centre, Caribbean Maritime University.

\section{Panel E: Critical Takeaways and Policy Relevant Highlights}

- Social media should be leveraged as a powerful tool to increase the visibility and accessibility of maritime and ocean careers to girls and women and provide an invaluable platform for networking, mentoring and research dissemination.

- Female role models and mentors can inspire and attract younger generations to sea-going careers, while empowering women in maritime and ocean fields to advance in their careers and seek leadership positions.
- Industry and maritime organizations should support and partner with women's networks to work toward closing the gender gap in the maritime industry.

- Companies that promote gender equality and women's empowerment should be identified and recognized. 


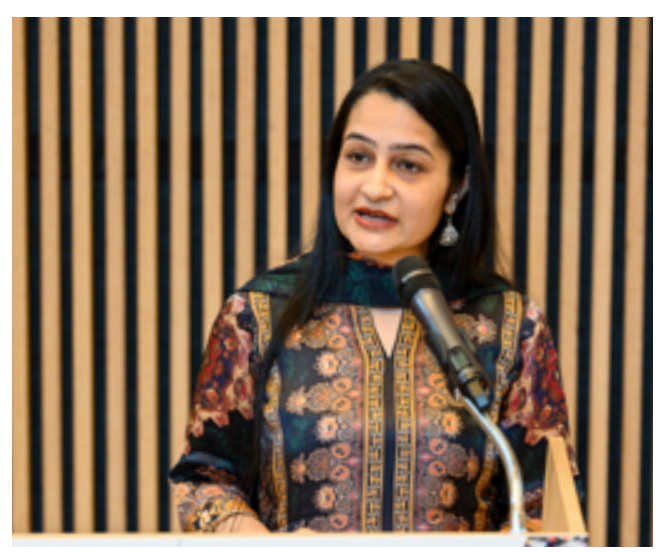

Ms. Sanjam Sahi Gupta, Director of Sitara Shipping Ltd.and member of the WMU Executive Board, began her presentation by sharing the story of how she came to work in the maritime industry. As a child, Ms. Gupta was enthralled by her father's stories about his experiences at sea and decided that this was something she wanted to do. Encouraged by her parents, she joined the family shipping business in 2001, and in 2012 established WISTA India to provide a platform for women in the maritime community. Ms. Gupta related a fruitful partnership experience that began when she was awarded the Sandvik India Gender Award. Sandvik, a Swedish company, sponsored her project to collect data on Indian women in the maritime industry. Ms. Gupta conducted a survey using the Norwegian SHE index, a tool to determine how friendly a company's policies are toward gender. She then carried out surveys to identify the needs of women working on-board and on-shore in terms of improving their work environment.

To date, 800 companies have responded to the survey. Ms. Gupta intends to use the results to represent women's voices in affecting ministerial and industry policy and decision-making. As a first step, she plans to ask top maritime industry CEOs to sign the WISTA pledge that they will work toward diversity in the maritime industry.

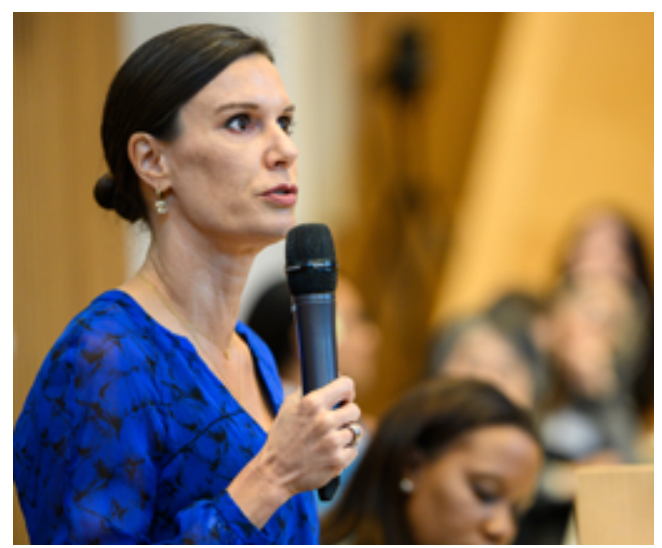

The second speaker, Captain Kate McCue of Celebrity Cruises, presented on behalf of Captain Patrick Dahlgren, Senior Vice President of Royal Caribbean Cruises Ltd., which is the owner of Celebrity Cruises. Captain McCue reminded the audience of the worldwide shortage of officers, which is forecast to reach 18.3 per cent by 2025, and discussed Celebrity Cruises' strategy to close this gap. The company's strategy of "doing the right thing that's right for business" involves disrupting the norm by championing gender equality at all levels of recruitment. As evidence, Captain McCue presented a photo of the all- female bridge team of the Celebrity Equinox, and noted that three of the ship's five executive committee members are female. Celebrity Cruises is proud of its progress toward gender equality. Captain McCue recalled that when she first joined Celebrity Cruises in 2015, there was a 3 per cent female representation on the bridge. Today it is 25 per cent, including 2 nd Officer and WMU graduate Ms. Nicoline Azirh Tifuh, one of the first female officers recruited from a West African country. On the company's newest ship, the Celebrity Edge, 30 per cent of officers and 30 per cent of the entire crew are female, while companywide 35 per cent of all new hires are female.

Ms. Lisa Lutoff-Perlo, the President and CEO of Celebrity Cruises, like Captain McCue herself, is very active on social media, providing influence and accessibility, which she says is key to attracting women to careers that were previously "shrouded in mystery". To sustain the drive for gender equality and diversity, the company is engaging in global partnerships with similar-minded, forward-thinking organizations, including the WMU, the Malala Fund, the United Way, and the Norwegian Seafarers' Union. Captain McCue concluded with words of encouragement for the audience: "Nobody can do you like you, and once you are you, you are a complete success story on your own." 
Dr. Kaoru Kubokawa is the founder of the networking mechanism, Women for One Ocean. In her presentation Dr. Kubokawa noted the low proportion of women in ocean-related activities in Japan. Despite being few in number, women ocean experts in Japan represent a wide range of fields and offer a variety of perspectives. To capitalize on the power of these women and to increase the proportion of women in ocean-related fields, Dr. Kubokawa, supported by a grant from the University of Tokyo Ocean Alliance Initiative, launched a project to establish the network Women for One Ocean, which has 70 members today. The Network's activities include the exchange of ideas through web meetings, production of booklets and website showcasing women's stories, and promoting ocean literacy among future maritime women and girls through visits to elementary schools. Dr. Kubokawa explained the key objectives and future direction of the Network, which include increasing the active role of women in ocean-related fields, especially in leadership positions, supporting the continuation of women's careers through support for child care and education, and making progress toward achieving Sustainable Development Goals 5 and 14.

The fourth speaker, Ms. Ore Toua is a Maritime Training Advisor for the Oceans and Maritime Transport division of the Pacific Community (SPC), the largest development agency in the Pacific. Her presentation focused on the role of the SPC in supporting gender mainstreaming in the Pacific at national, regional and international levels through a networking and project-based approach and through its support of the Pacific Women in Maritime Association (PacWIMA). She explained how under the Geoscience, Energy and Maritime division of SPC, gender mainstreaming is practiced in all areas of work, identifying, supporting and demonstrating competencies of women in oceans and maritime transport.

To further increase the engagement of women in the maritime sector, SPC and Ms. Toua herself were instrumental in relaunching PacWIMA in 2016. Since then, eight national WIMA chapters have been mobilized at the grassroots level to continue to mainstream gender, with evidence of prioritization of women shifting regionally. SPC supports PacWIMA through two entry points. It engages with national WIMAs, promoting women's participation and career advancement through leadership programmes and, in parallel, leverages its partnerships and networks through a project approach. As an example, Ms. Toua introduced an MTCC-Pacific led pilot-project on the uptake of ship energy efficient technologies, on which two women ship operators have been engaged in data collection. The speaker left the audience with some golden nuggets of advice to increase the engagement of women:

"CREATE A SPACE, SEIZE THE OPPORTUNITY, BUILD RELATIONSHIPS, ALLOW COUNTRIES TO DETERMINE THE APPROACH AND ENCOURAGE COUNTRIES TO TAKE A LEADING ROLE."
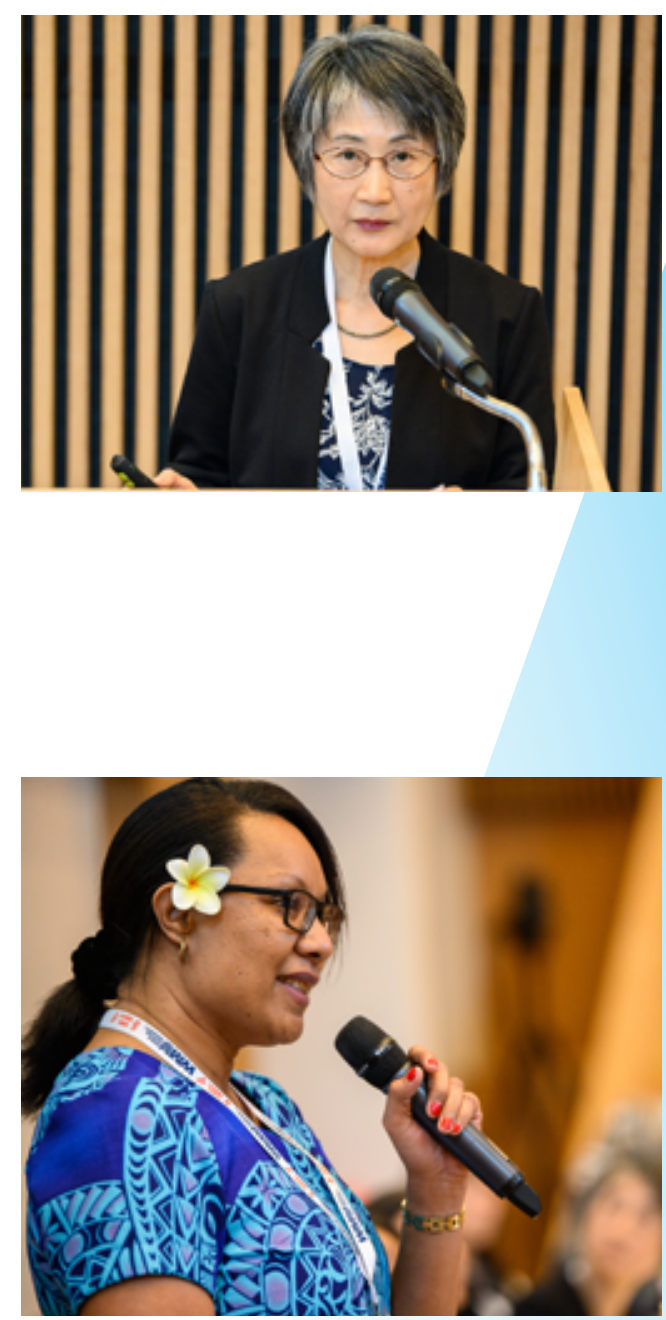

MS. ORE TOUA 


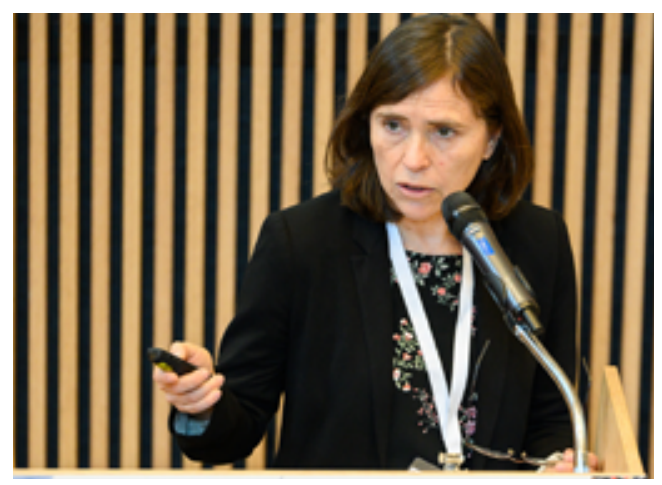

Dr. Milena Arias Schreiber, Researcher and Project Leader at the Swedish Institute for the Marine Environment, Gothenburg University, presented the Too Big to Ignore Network (TBTI). TBTI is a research network and knowledge mobilization partnership for small-scale fisheries. It currently has a membership of over 300 researchers in 45 countries worldwide. The network aims to elevate the profile of smallscale fisheries and argue against their social, political and cultural marginalization in national and international policies.

It also develops and disseminates research in a number of thematic clusters, including food security, sustainability challenges, and women and gender, in the form of articles, books, conferences and campaigns. Members can share and access research from different disciplines and perspectives while working toward a common goal. Dr. Schreiber described how on International Women's Day, the network provided a platform for members to share photos and stories and post information on cases of small-scale fisheries related to women. Such stories came from all over the world and included a woman from South Africa who is fighting for fishing rights, as well as a project in Canada that teaches girls to fish. In closing, Dr. Schreiber invited the audience to join an upcoming webinar on gender equality and equity on the network's webpage.

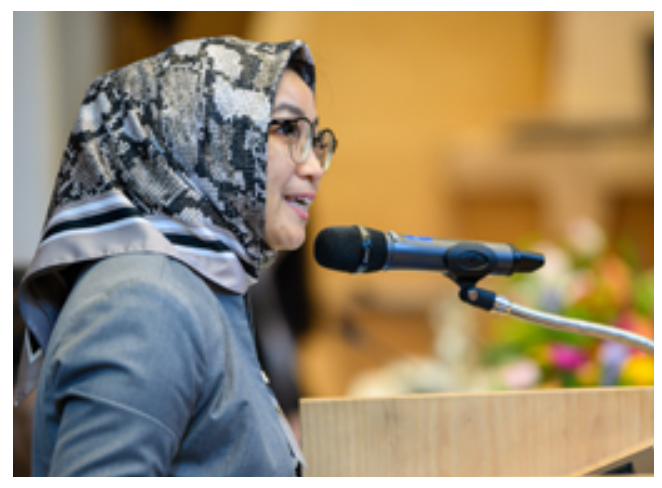

The next speaker, Ms. Siti Noraishah Azizan is the General Manager of Sabah Ports in Malaysia as well as the Chair of the International Ports and Harbours Association (IPH) Women's Forum. Ms. Azizan described the IPH Women's Forum's approach as "working hand in hand with men to facilitate women's advancements in maritime professions." Its objectives include the promotion of more women to leadership roles, the creation of platforms to discuss women's issues and as a channel to encourage women to join the industry, and the development of training programmes to enable women to compete for positions at all levels.

Ms. Azizan shared a number of initiatives implemented by the Forum and future undertakings toward the achievement of these objectives. The first initiative is the establishment of the Women's Forum Awards Scholarship, which is open to all member ports and provides an opportunity for women at managerial levels to achieve their goals of advancement in the port industry. A second initiative, the IPH exchange programme, provides women at the executive level experience and exposure to best practices at international ports.

Finally, the Forum recognizes ports that promote gender equality and empower women with its Port Excellence Award. Ms. Azizan concluded her presentation with a message about the importance of partnerships and networking:

\section{"PARTNERSHIP WITH OTHER PORTS, RELATED ASSOCIATIONS AND WOMEN'S ORGANIZATIONS ARE VERY CRITICAL TO BRING ABOUT THE WAVES OF CHANGE IN THE GENDER EQUALITY AGENDA."}

MS. SITI NORAISHAH AZIZAN 
The final speaker in this panel, Ms. Ally Cedeno, is the Founder and President of the Women Offshore Foundation, a resource centre and mentoring organization for women seafarers. Ms. Cedeno told the audience about the challenges she faced as a female seafarer, and how experiencing bullying and sexual harassment initially held her back:

"IF THEY DIDN'T RESPECT MY VOICE, HOW WAS I SUPPOSED TO BECOME A CAPTAIN? I DIDN'T BELIEVE IN MYSELF. I NEEDED A MENTOR"

\section{MS. ALLY CEDENO}

Ms. Cedeno related how in 2015, after being posted to a drill ship with a lot of women on board, she found the mentorship she had been looking for. The sense of belonging and the comradery helped her to thrive and come into her own, and from this experience, the idea for Women Offshore was born. Ms. Cedeno set up the website on which she profiled women seafarers. She found that "women seafarers had amazing sea stories with lessons learned, challenges overcome and accomplishments made that could be passed on to other women"

She also discovered that, like herself, women were asking for mentors, so she created a pilot mentorship program, free and open to any woman seafarer, regardless of experience. This has grown into a full-fledged company-sponsored program with 130 participants that not only provides women with mentorship but opens doors to new career opportunities. Further resources such as a podcast and an annual conference have been added, and Ms. Cedeno aims to grow the network of mentors and mentees until it reaches 1,000 female seafarers. Most of Women Offshore's activities happen online and Ms. Cedeno champions the use of social media to reach women and reduce the gender gap in the maritime industry:

"You are opening a window for people to look into and see that women are actually doing this ... these stories get shared thousands of times."

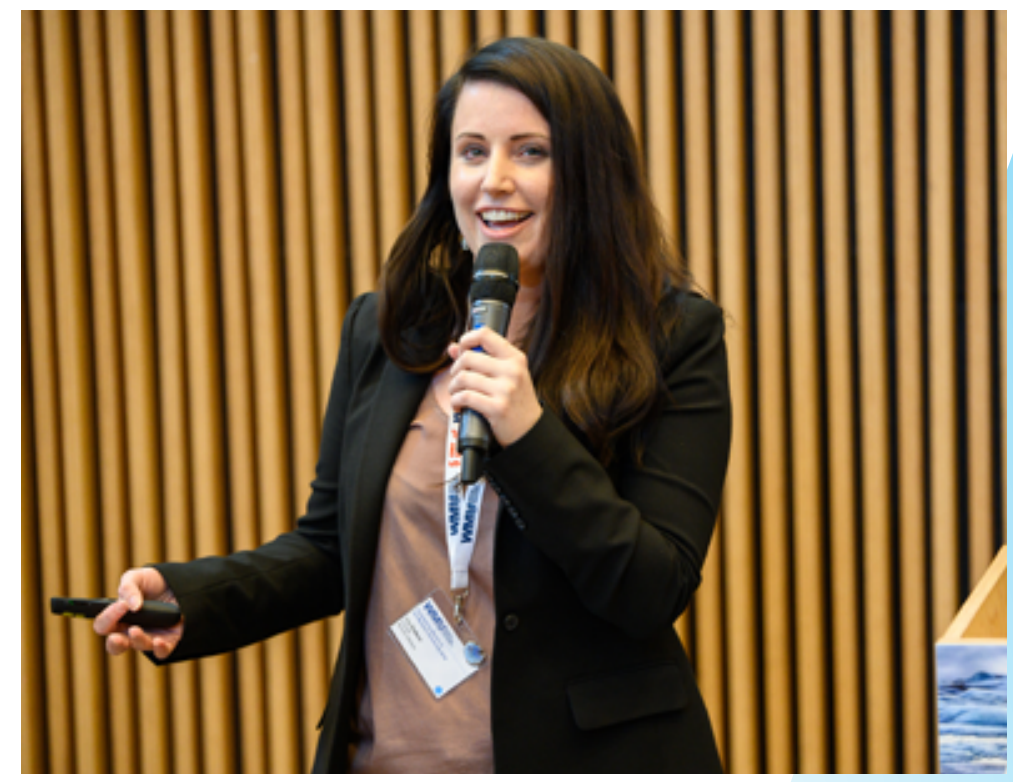




\section{RESEARCH SESSIONS}

The Conference announced a call for papers to invite the submission of original research articles of high quality and forward-thinking that seek to advance achievement of the SDGs. Topics focused on SDG 5 and gender equality in maritime and related ocean fields were of particular relevance. Furthermore, the Conference welcomed a focus on additional SDGs, such as, but not limited to: Goal 1 (end of poverty), Goal 4 (quality education), Goal 7 (affordable and clean energy), Goal 8 (decent work), Goal 9 (industry, innovation, and infrastructure), Goal 12 (responsible consumption and production), Goal 13 (climate action), Goal 14 (life below water), Goal 16 (peace, justice, and strong institutions), and Goal 17 (partnerships for the goals). Following a peer review, selected papers will be published in the Special Issue of the WMU Journal of Maritime Affairs to mark this very special occasion.

In total, the Conference attracted 45 abstracts from both female and male authors in 23 countries (5 Asian; 2 North American; 2 South American; 2 Caribbean; 1 Middle East; 2 African; and 9 European countries). Sixteen papers were selected for oral research presentations, divided into four sessions: 1) Increasing the visibility of women of the sea; 2 ) Maritime safety and security from gender perspectives; 3 ) Empowering women in maritime business and trade; and 4) Closing the gender gap in the maritime community. In addition, poster research presentations accommodated 8 presenters

\section{RESEARCH PRESENTATION-1: INCREASING THE VISIBILITY OF WOMEN OF THE SEA} Session Chair: Dr. Irini Papanicolopulu, Associate Professor of International Law, Università di Milano-Bicocca

The research presentations in Session 1 highlighted the obstacles and barriers faced by women in the fisheries and seafood sector. The prevailing message is that there is a need to increase the visibility of women's work and to raise awareness of and change prevailing traditional gender roles, segregation and discrimination against women. The aim is to make the sector more inclusive and more sustainable. 
1-1. Ms. Alexandra Aguilar del Valle, Founder Green Nautical Miles, Global Transportation Strategy

In her presentation, "Canada's Ocean's Protection Plan, Empowering Women to Protect our Legacy", Ms. Aguilar focused on Canada's commitment to upholding gender equality in the maritime sector through its national strategy, the Ocean Protection Plan. In support of diversity and with a goal to reduce the gender gap in Canada's maritime industry, the Plan focuses on women in indigenous and coastal communities, aiming to increase their participation in marine safety jobs through education and training programmes.

1-2. Ms. Natalia Briceno, WSI Consultant, the International Association for Women in the Seafood Industry

"The seafood industry is not attractive to women: Is it really? Putting gender on the agenda of the seafood industry" presents the results of a global survey aimed at detecting barriers to gender equality in the seafood sector. The study identified a chain of causes and consequences that shape gender relations in the sector, including a lack of incentives at school level to attract women to the sector, working conditions unfavourable to women and systematic bias, discrimination and stereotyping against women in the industry. Ms. Briceno concluded that in order to make progress toward equality, gender mainstreaming and training were needed to address the lack of understanding about the issue.

1-3. Dr. Madeleine Gustavsson, Research Fellow, University of Exeter

In "Gender (in)equalities on the coast? Exploring women's changing roles, identities and wellbeing in small-scale fishing families of the UK", Dr. Gustavsson reported on her ongoing research project. She is interested in understanding what women are doing in the context of small-scale fishing families, how their fishing and non-fishing work contributes to ensuring the survival of the small-scale fishing sector and, finally, how women describe their well-being and quality of life and how they understand the power and strength they get from their work. Dr. Gustavsson hopes to use the results of her research to raise the profile of women fishers, and to develop recommendations for the post-Brexit UK fishing policy. She also sees the potential for the establishment of a women-in-fishing network.

1-4. Dr. Emma Rodríguez Rodríguez, Associate Professor, Labour Law and Social Security Law, University of Vigo

In her presentation, "Labour and social conditions of women workers at sea", Dr. Rodriguez highlighted the horizontal and vertical segregation of women in the fishery sector, with special reference to Spain. Women in the maritime and fishing sector are frequently absent or poorly represented in decision-making and managerial positions. Their work is often less visible or seen as secondary to that of men, resulting in poor regulation of women's specific work and limited access to social security protection, including pensions. Dr. Rodriguez emphasized the need for regulations that improve social and labour conditions for female workers and allow them to enjoy the same rights, benefits and recognition as men.
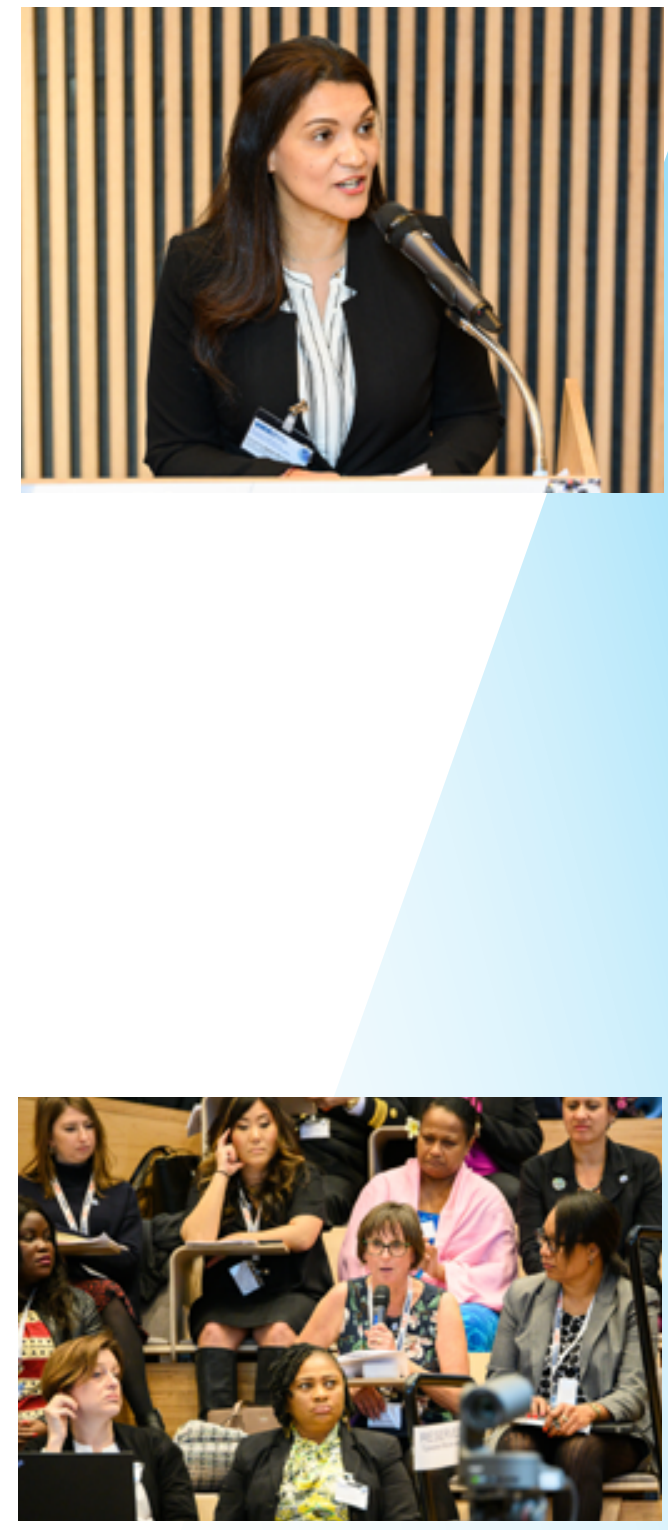


\section{RESEARCH PRESENTATION-2: MARITIME SAFETY AND SECURITY FROM GENDER PERSPECTIVES}

Session Chair: Dr. Laura Carballo Piñeiro, Professor, WMU

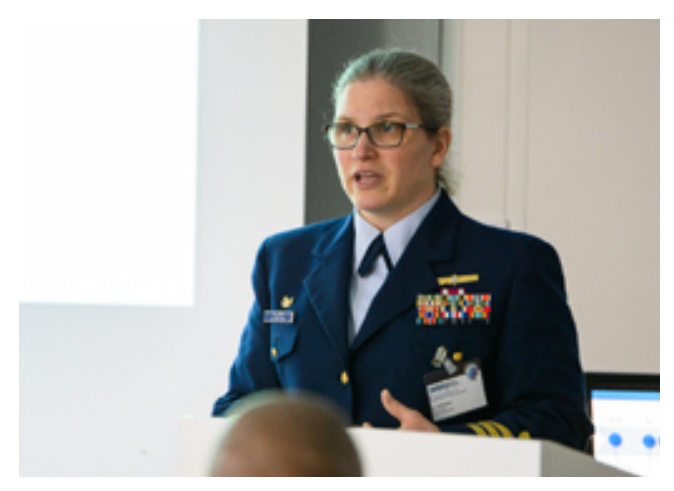

The basis of Research Session 2 was that the gender perspective is rarely present in maritime safety and security policies, strategies and studies. And when it was, it was not properly implemented.

2-1. Commander Patricia Tutalo, Gender Policy Advisor, Office of Diversity and Inclusion, U.S. Coast Guard (USCG); Commander Erin Williams, Marine Safety Unit Duluth, USCG and Chair, CG Women's Leadership Initiative

The presentation "Recipe for Success: Key Ingredients to Create an Inclusive Environment for Women" highlighted that the lack of a gender perspective in maritime industries is driving women out of employment by, for example, not taking into account their physical parameters and applying tailored-made ergonomic measures along with appropriate conciliatory measures. All in all, a culture change is required.

2-2. Dr. Isabel Lirola-Delgado, Associate Professor for International Public Law, University of Santiago de Compostela

"Maritime Security Strategies and Gender Perspective: Implications for the Development of United Nations SDG 5" focused on the European Union Maritime Security Strategy and the Spanish National Maritime Security Strategy as examples of the invisibility of the gender dimension, to suggest means of enhancing this approach in the stated strategies.

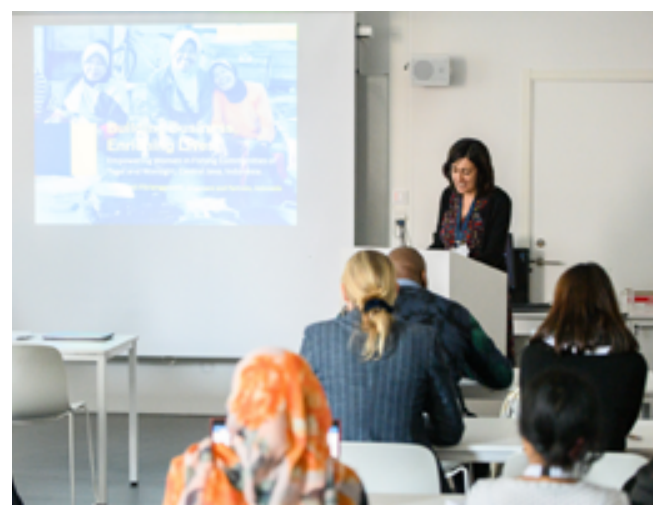

2-3. Ms. Sayedeh Hajar Hejazi, Researcher and Consultant, Human Rights at Sea

Seafarer abandonment and, in particular, the Geneva Declaration on Human Rights at Sea, launched by Human Rights at Sea, were the focus of Ms. Hejazi's presentation. Her presentation sought to raise awareness of the urgent need for a human-rights based approach on board ships.

2-4. Ms. Setyawati Fitrianggraeni, Managing Partner, Anggraeni and Partners, Indonesia

In "Building Business, Enriching Lives: An Indonesian Initiative to Empower Women in the Fishing Communities", Ms. Fitrianggraeni shared a business cooperative (Indonesian Koperasi) model that not only energizes community life with women as its driving force, but also enhances maritime safety and security by making the family aware of the professional risks. 


\title{
RESEARCH PRESENTATION-3: EMPOWERING WOMEN IN MARITIME BUSINESS AND TRADE
}

\author{
Session Chair: Dr. Momoko Kitada, Associate Professor, WMU
}

Session 3 focused on the challenges and opportunities for women in maritime business and trade sectors. The session informed that the low representation of women in maritime business and trade, including managerial and leadership positions, can be solved through a strategic priority with technology, gender-sensitive training, women leadership policies and assessment tools.

3-1. Ms. Laura Burns, Technical Communications; Ms. Lucy King, Marketing Manager; Ms. Kattie Lam, Product Manager; Ms. Valeria Surk, Product Specialist; Veson Nautical

A well-coordinated joint presentation by four speakers, entitled "The Impact of Digital Transformation on Gender Equality in Commercial Maritime", noted how digital technology can support gender equality in the commercial maritime sector. Based on a survey, the research highlighted the fact that technology will create more roles and opportunities for maritime women and also support the advancement of women if technology is a strategic priority.

\section{3-2. Dr. Pınar Ozdemir, Piri Reis University}

"A Journey to Maritime Women Leadership: Project Mentoress" shared the outcome of the project Mentoress under the scope of Erasmus+ Key Action2 Strategic Partnerships, involving Bulgaria, Poland, Romania and Turkey. It aims to provide leadership and intercultural communication skills to female cadets through curriculum change. Through questionnaires and workshops, the collected data were used to establish gender-sensitive syllabi for maritime education and training institutions.

\section{3-3. Dr. Aspasia Pastra, Research Associate, WMU}

Women's representation on Boards of Directors is one of the indicators to measure women in maritime leadership. The paper, entitled "Women in the Board of Directors: The Case of Greek Listed Companies, provides a case study of the Greek maritime industry and highlights the extremely low representation of women (6 per cent) on boards of directors. Based on the research, the real obstacle in the appointment of women to leadership positions lies in the lack of urgency given to this issue.

3-4. Ms. Meenaksi Bhirugnath-Bhookhun, Former Chairperson of the Association of Women Managers in the Maritime Sector in East and Southern Africa (WOMESA)

The presentation, entitled, "Beyond Business-As-Usual: The role of women professionals in maritime clusters", assessed the application of Rapid Integrated Assessment (RIA) as a tool to increase gender equality in maritime clusters. The study indicates the usefulness of RIA to identify the gender gap and help determine where to build capacity in selected maritime clusters in Japan, Norway and Singapore.

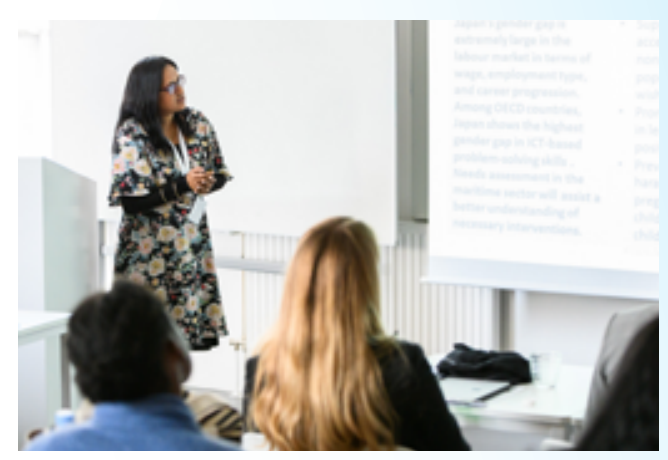




\title{
RESEARCH PRESENTATION-4: CLOSING THE GENDER GAP IN THE MARITIME COMMUNITY
}

\author{
Session Chair: Dr. Maximo Q. Mejia Jr, Professor, WMU
}

Session 4 focused on closing the gender gap in the maritime community through a number of different perspectives. The session started with a presentation on the potential impact of autonomous shipping on gender parity, followed by a presentation on the role of maritime education and training in the Caribbean both in promoting gender equality and in enhancing the performance of the maritime sector. The third presentation gave participants some provocative food for thought: would an all-women shipping company promote gender equality? Last but not least, the fourth presentation surveyed Philippine law and policy developments in promoting opportunities for women and institutionalizing gender balance in sea-based careers, and assessed their effectiveness.

4-1. Ms. Tae-eun Kim and Mr. Amit Sharma, Doctoral Research Fellows, Department of Maritime Operations, University of South-Eastern Norway

In their presentation, entitled, "Achieving gender parity in maritime industry: barriers and opportunities in the era of autonomous shipping," Ms. Kim and Mr. Sharma take the premise that autonomous technological advancement is considered to be a major step in terms of change in the world of shipping, creating new opportunities and challenges with significant impact for the personnel involved, both on-board and on-shore. They presented their investigation into whether disruptive changes with regards to autonomy will lower the barriers of employment opportunities for women seafarers/operators in the merchant shipping industry. The findings from their study can shed light on the means to achieve gender parity in the maritime industry and help address the strategic directions of the IMO and the UN SDGs.

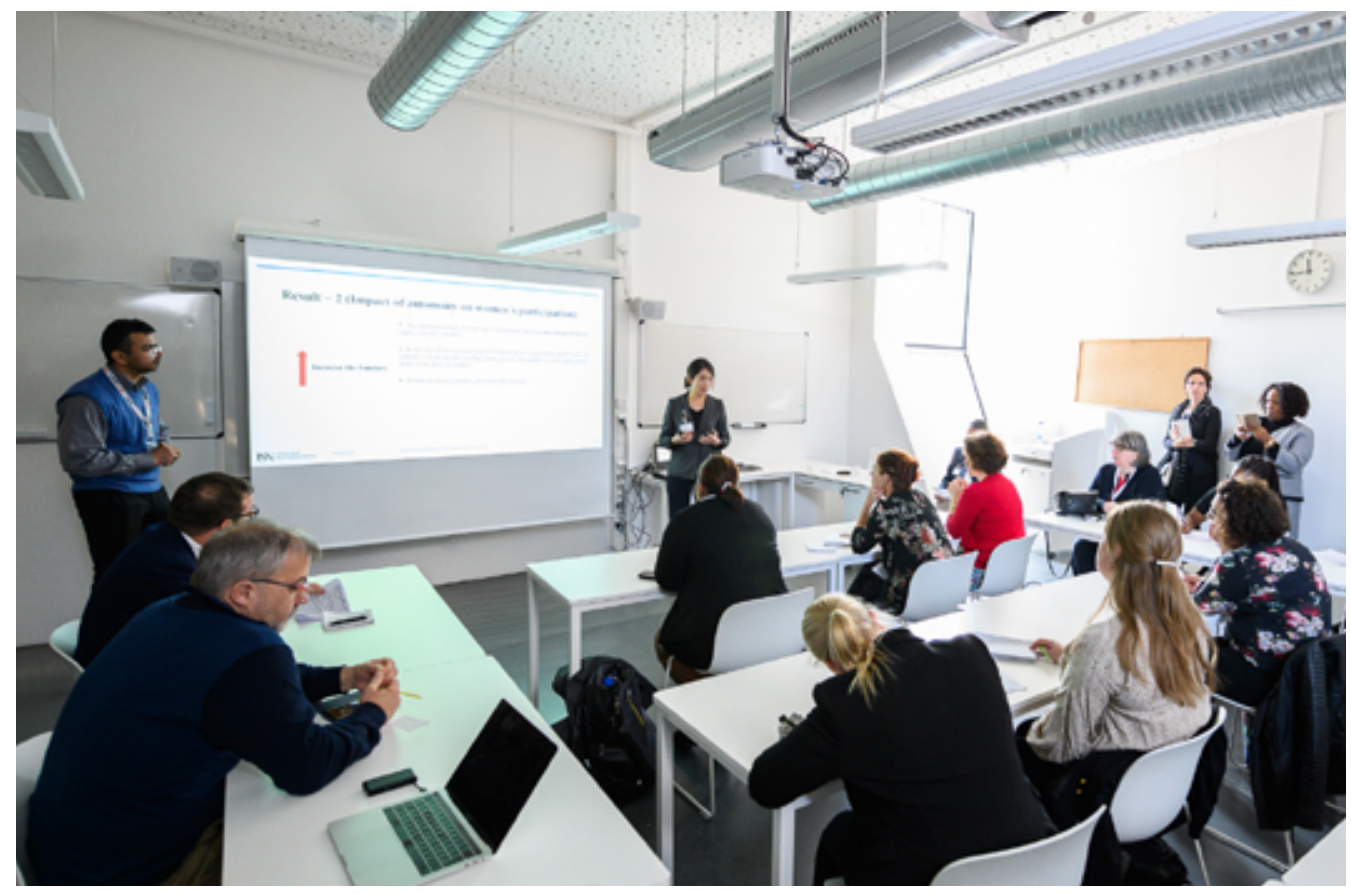


4-2. Ms. Sarita Mahabir-Lee, Senior Instructor; Ms. Vivian Rambarath-Parasram, Assistant Professor, University of Trinidad and Tobago

Dr. Mahabir-Lee and Dr. Rambarath-Parasram presented their study, "Forging ahead: leveraging inclusive and equitable education to bridge the gender gap," which provides a maritime gender baseline for maritime education and training (MET) in the Caribbean region. Policies, laws, relevant international instruments, human development reports, along with the level of implementation in relation to UNSDGs, Goal 4 (quality education) and Goal 5 (gender equality), are examined in reference to MET. Increasing the number of female seafarers is an imperative for the sector as research indicates that female participation on corporate boards effectively enhances financial performance. In their presentation, they concluded that leveraging inclusive education is an important tool for promoting gender equality and enhancing the performance of the maritime sector.

\section{4-3. Mr. Tom Storey, 2nd Officer, United Kingdom}

Mr. Storey gave the presentation, entitled "Can gender balance be achieved in the shipping industry? Exploring the possibility of an allwomen shipping company." The key aim was to extend knowledge as to why so few women work at sea. Limitations within current figures mean that the true seafaring figures are distorted as the 2 per cent includes all employees on-board cruise ships, including hotel staff. The presentation proposed that an all-women crewed ship in the merchant navy would create a more desirable working environment that, among others, would give female juniors, cadets and crew better access to mentors, who will be more approachable and without the threat many females have faced working at sea. It also broached the idea of an all-women shipping company and asserted that an allwomen shipping company would be the quickest and safest method to increase the number of women seafarers, hopefully bringing true gender balance to the shipping industry.

\section{4-4. Dr. Maria Emilynda Jeddahlyn Pia V. Benosa,}

Lawyer, Senior Researcher, Institute for Maritime Affairs and Law of the Sea, University of the Philippines

Through her presentation, "She-based: developments in promoting occupational gender balance for Filipino women seafarers," Dr. Benosa reviewed Philippine legal and policy developments in promoting opportunities for women and institutionalizing gender balance in sea-based careers. The first part explored the impact of statutory enactments, such as the Philippines' Women in Development and Nation-Building Act and the Magna Carta of Women, on the deployment of women seafarers. The second part was a case study profiling women seafarers in industries where women are least deployed, including offshore mining operations. The third part examined the nature of complaints and claims, involving women seafarers, filed before Philippine administrative agencies. Results of the above were evaluated for compliance with the Convention on the Elimination of All Forms of Discrimination Against Women (CEDAW), the International Labour Organization, and IMO standards, and the Philippines' own national targets, among others, in promoting occupational gender balance in sea-based careers.

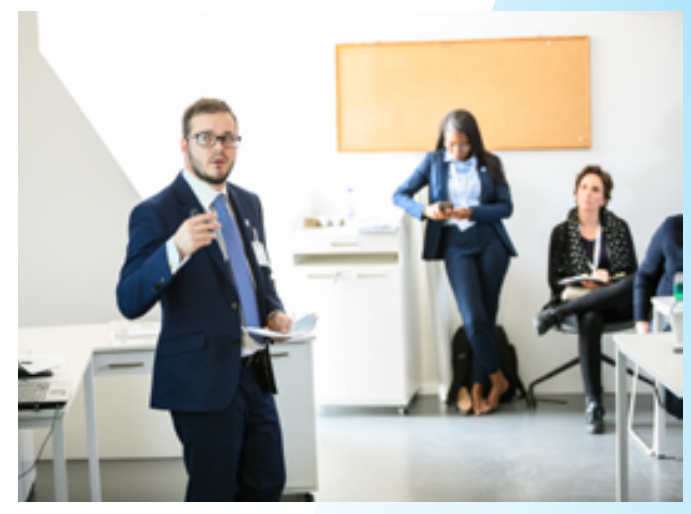




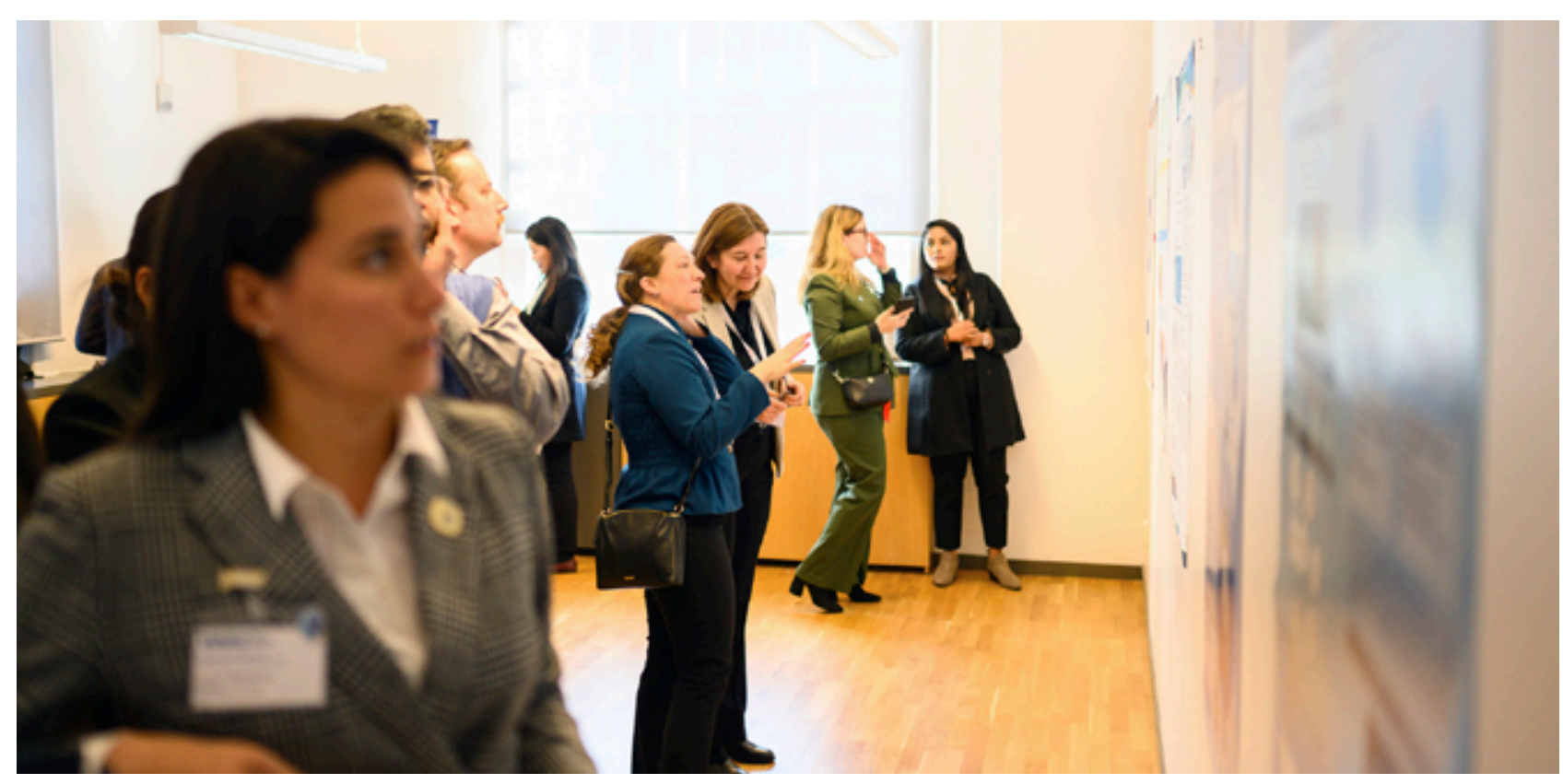

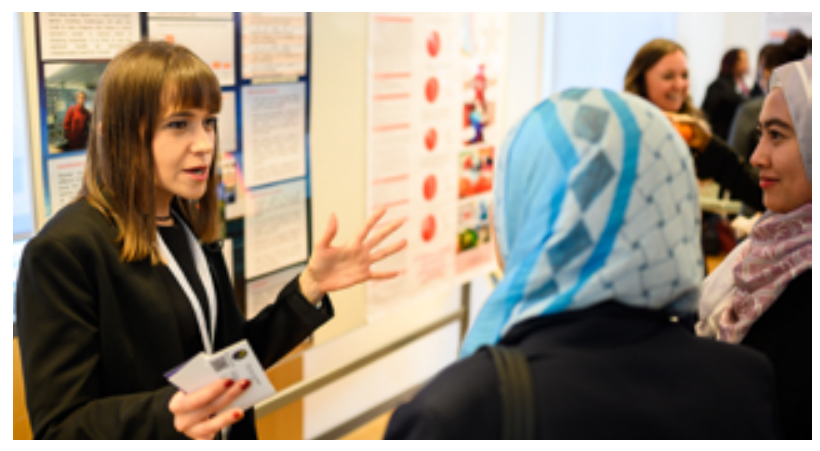

\section{POSTER RESEARCH PRESENTATIONS}

The Organizing Committee expresses its thanks to all the poster research presenters: Ms. Ayse Asli Basak; Ms. Chrysanthe Kolia; Dr. Dwynette D. Eversley; Dr. Nihan Şenbursa; Dr. Pinar Özdemir; Ms. Seray Karlav; Ms. Rita de Cassia; and Ms. Pratiksha Parsan.

Through the research sessions, WMU created an evidence-based forum to

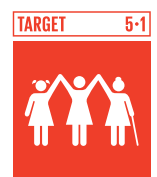

\begin{tabular}{l}
\hline ENDDISCRIMINATION \\
AGAINSTWOMENAND \\
GIRLS
\end{tabular} discuss the following targets within Goal 5:

Target 5.1: End Discrimination Against Women and Girls

End all forms of discrimination against all women and girls everywhere.

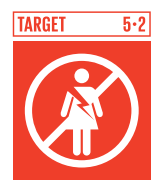

END ALL VIOLENCE
AGAINST AND
EXPIIITION MEPLOITATIONOF
WOMENANG GIRLS
Target 5.2: End All Violence Against and Exploitation of Women and Girls

Eliminate all forms of violence against all women and girls in the public and private spheres, including trafficking and sexual and other types of exploitation.
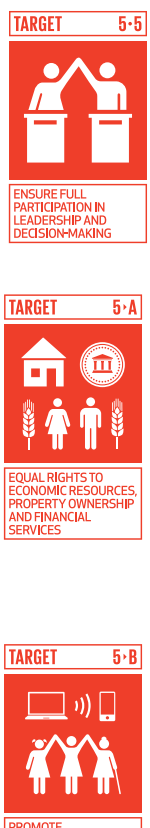

PROMOTE
EMPOWERMENT OF
WOMENTHROUG

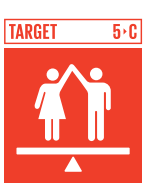

ADOPTAND STRENGTENPOLCAS
ANENEREALE
LEGISATIONFOR
Target 5.5: Ensure Full Participation in Leadership and Decision-Making Ensure women's full and effective participation and equal opportunities for leadership at all levels of decision-making in political, economic and public life.

\section{Target 5.A: Equal Rights to Economic} Resources, Property Ownership and Financial Services

Undertake reforms to give women equal rights to economic resources, as well as access to ownership and control over land and other forms of property, financial services, inheritance and natural resources, in accordance with national laws.

\section{Target 5.B: Promote Empowerment of} Women through Technology

Enhance the use of enabling technology, in particular information and communications technology, to promote the empowerment of women.

\section{Target 5.C: Adopt and Strengthen} Policies and Enforceable Legislation for Gender Equality

Adopt and strengthen sound policies and enforceable legislation for the promotion of gender equality and the empowerment of all women and girls at all levels. 


\section{OTHER EVENTS}

\section{PRESENTATION ON THE IMO'S GENDER PROGRAMME}

\section{Ms. Helen Buni}

Programme Assistant, Technical Cooperation Division, IMO.

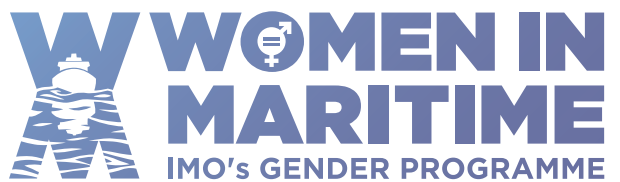

Through its Women in Maritime (WIMA) programme, IMO has been driving for change towards more gender equality in the maritime professions under the slogan "Training, Visibility, Recognition". The programme was initiated in 1998 when only a few maritime training institutions opened their doors for women to study maritime subjects. Since then, the IMO has actively and strongly supported increasing opportunities for women to access maritime education. An institutional framework was established to incorporate gender dimensions into IMO policies and procedures.

Education promotes equality and empowers women. Today, the IMO supports gender equality and the empowerment of women through specific fellowships, facilitating access to high-level technical training for women in the maritime sector in developing countries. For example, a long-running Women in Port Management course is hosted in Le Havre, France, every year. In total, 308 women have received training through this initiative alone. Despite the high demand, funding is a challenge. Two maritime training institutions established by the IMO have recently achieved a significant milestone. The WMU celebrated the thousandth female graduate in 2018, and the IMO International Maritime Law Institute (IMLI) in Malta became the first United Nations body to include a clause in its Statute requiring that 50 per cent of places are reserved for women.

The IMO has facilitated the creation of professional networks to improve gender balance in the shipping industry. Under the IMO's auspices, seven Women in Maritime Associations (WIMAs) have been established in Africa, Arab States, Asia, the Caribbean, Latin America and the Pacific, covering some 152 countries and dependent territories and 490 participants. These regional associations provide a membership platform to discuss a whole range of issues, including but not limited to gender. Through the IMO, each regional network has been encouraged to establish national chapters which have delivered maritime career days and various activities, such as information on HIV prevention and sexual health, and beach clean-ups.

This grass-roots-level activity has made women more visible to the wider community. The IMO also created a new logo for women in the maritime sector to increase the visibility of women. Social media is such a powerful tool to raise the visibility and profile of women in the maritime sphere for donor support. So far, the IMO has produced three short films on gender diversity and inclusion videos to showcase the success stories of how its gender and capacity-building programme has benefited women in port, shore-side and on-board ships.

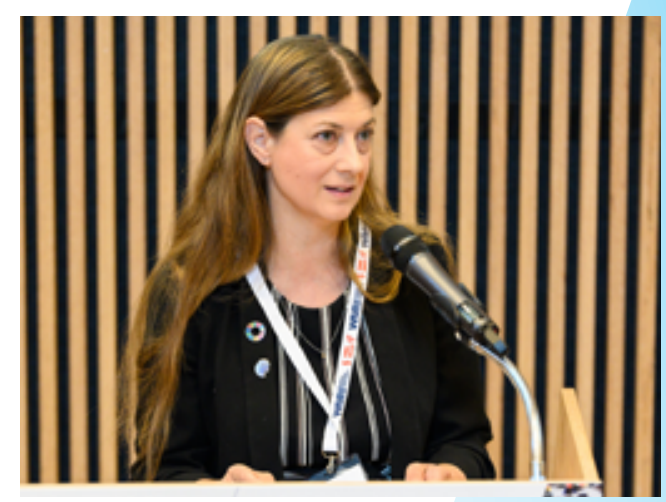




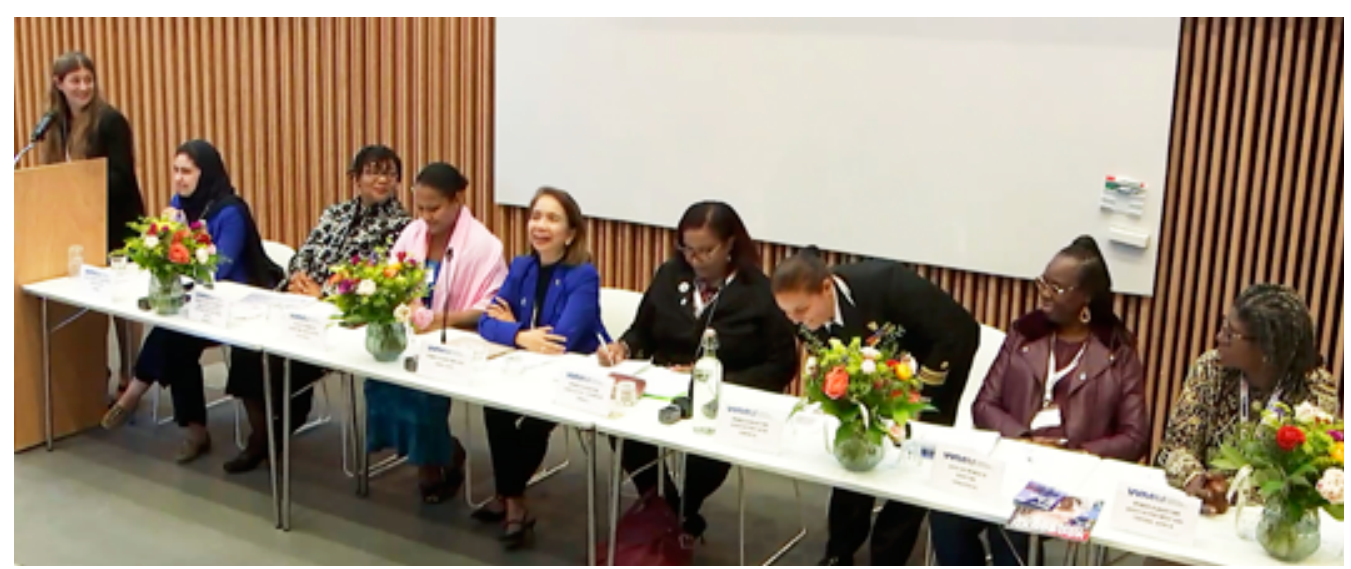

\section{WIMAS AND WMUWA PANEL}

The IMO has facilitated the creation of professional networks to improve gender balance in the shipping industry, the Women in Maritime Associations (WIMAs) in Africa, Arab States, Asia, the Caribbean, Latin America and the Pacific, covering some 152 countries and dependent territories and 490 participants. With generous funding from IMO and the Maritime and Coastguard Agency of the United Kingdom, the Conference sponsored two representatives from each regional WIMA to report on their activities and share their challenges with other regional WIMAs. The WMU Women's Association (WMUWA) also participated in this panel discussion.

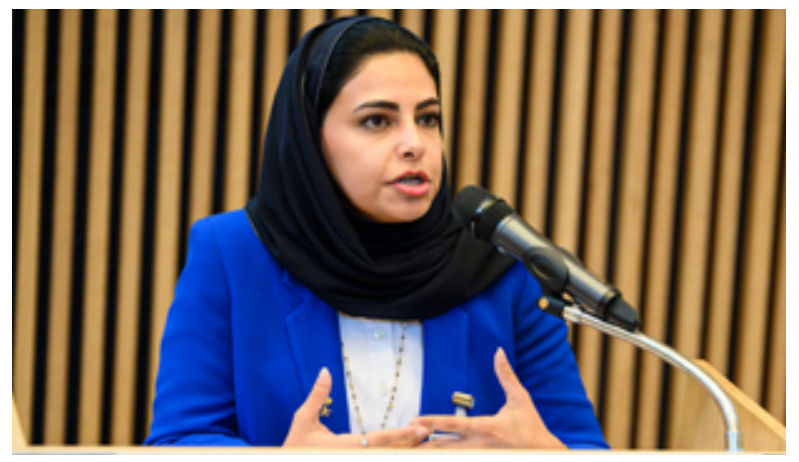

Arab Women in Maritime Association (AWIMA), was established in Egypt in October 2017 (http://www.arabwima.org)

The first elected President of AWIMA, Ms. Wijdan Alsuhaibani, explained that as one of the youngest WIMAs, AWIMA is still learning about ways in which the network enables Arab women in the maritime sector to build their capacities. A cross-association cooperation has already begun. More mature associations like WOMESA support AWIMA in terms of sharing their know-how and best practices.

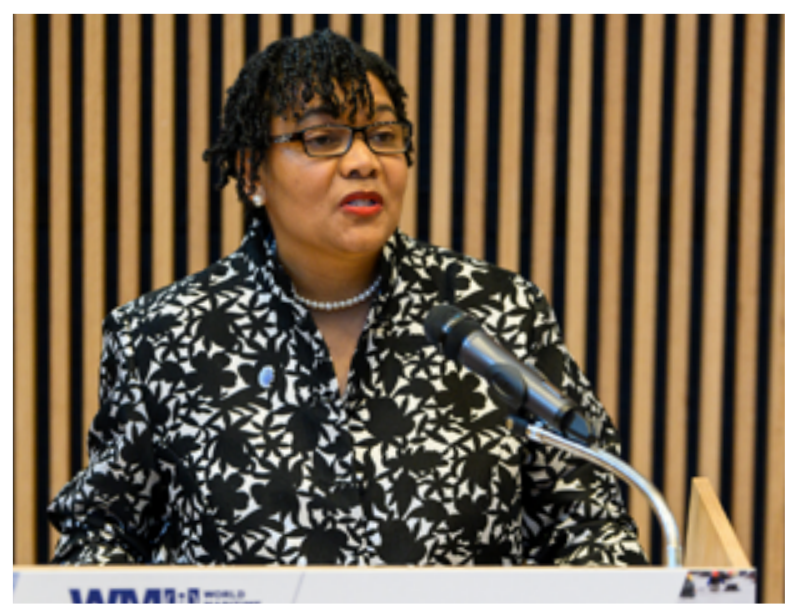

Association for Women in the Maritime Sector in Eastern and Southern Africa region (WOMESA), was established in Kenya in December 2007. (http://womesa.org)

The Chairperson of WOMESA, Ms. Marjorie Lorraine Masiza, expressed her appreciation to the IMO for their fellowship support to many WOMESA members who have accessed maritime higher education. WOMESA disseminated the information to enable more women to gain knowledge and drive for change. Other focus areas are mentorship, operationalization of gender policies in the workplace, resource mobilization through fundraising, and increasing visibility through stakeholder engagement. WOMESA set a target to ensure all Secretariats of the 12 WOMESA national chapters set up offices in their respective countries. 
Pacific Women in Maritime Association (PacWIMA) was set up in Fiji in February 2004 and relaunched in Tonga in April 2016. (http://www.pacwima.org)

When reporting on the progress of national chapters under PacWIMA, the President of PacWIMA, Ms. Jane Koi, reported that eight State WIMAs have been established so far and six are in progress to join PacWIMA. During the 2nd PacWIMA regional conference in Port Moreby, Papua New Guinea, a drafting committee for a regional strategy document for women in maritime in the Pacific was established. This regional strategy is a reflection of the region's commitment to empower Pacific women in the maritime sector. It calls for greater collaboration, strengthening existing alliances, and forging new partnerships. It articulates the aspiration of PacWIMA. Another achievement was to identify 18 May as the Day of Women in Maritime to be celebrated worldwide.

Women in Maritime Association, Asia (WIMA Asia) was established in January 2010 and re-launched in the Philippines in 2015 (https://www.facebook.com/wimaasia/)

Dr. Merle Jimenez-San Pedro, President of the Women in Maritime Association, Asia (WIMA Asia) quickly reviewed the history of WIMA Asia. During its establishment in 2010, WIMA Asia was inspired by the United Nations Millennium Development Goal 3 (gender equality). WIMA Asia participated in a regional workshop on green shipping (Manila, Philippines) in 2012; a regional conference on the development of a global strategy for women seafarers (Busan, South Korea) in 2013 and a regional conference on domestic ferry safety (Manila, Philippines) in 2015. WIMA Philippines (WIMA-Phil) has a longer history as it was established in 2007. WIMA-Philippines served as the core of WIMA Asia until 2017 when WIMA-Asia was formally established in Timor-Leste. Today, WIMA Asia has four national chapters to lead the association with much stronger governance, and is expecting four more chapters to be established. With various gender-sensitizing activities, WIMA Asia continues to promote SDG 5 (gender equality) and other Goals but recognizes cultural barriers for women and funding as the main challenges.

Women in Maritime Association, Caribbean (WiMAC), was set up in Jamaica in April 2015. (http://wimacaribbean.com)

Dr. Dwynette Dellena Eversley, President of WiMAC and a WMU graduate, called for support by all WIMAs for the establishment of a global code of conduct on gender mainstreaming in the maritime sector. WiMAC is eager to understand gender gaps using data. A survey was conducted on issues on Caribbean maritime women. It helps to identify strategic partnerships for WiMAC, such as the one they share with the Caribbean Shipping Association. In addition to the efforts of the IMO, it was suggested that IMO should consider creating a directorate of women to strengthen an institutional function for gender equality.
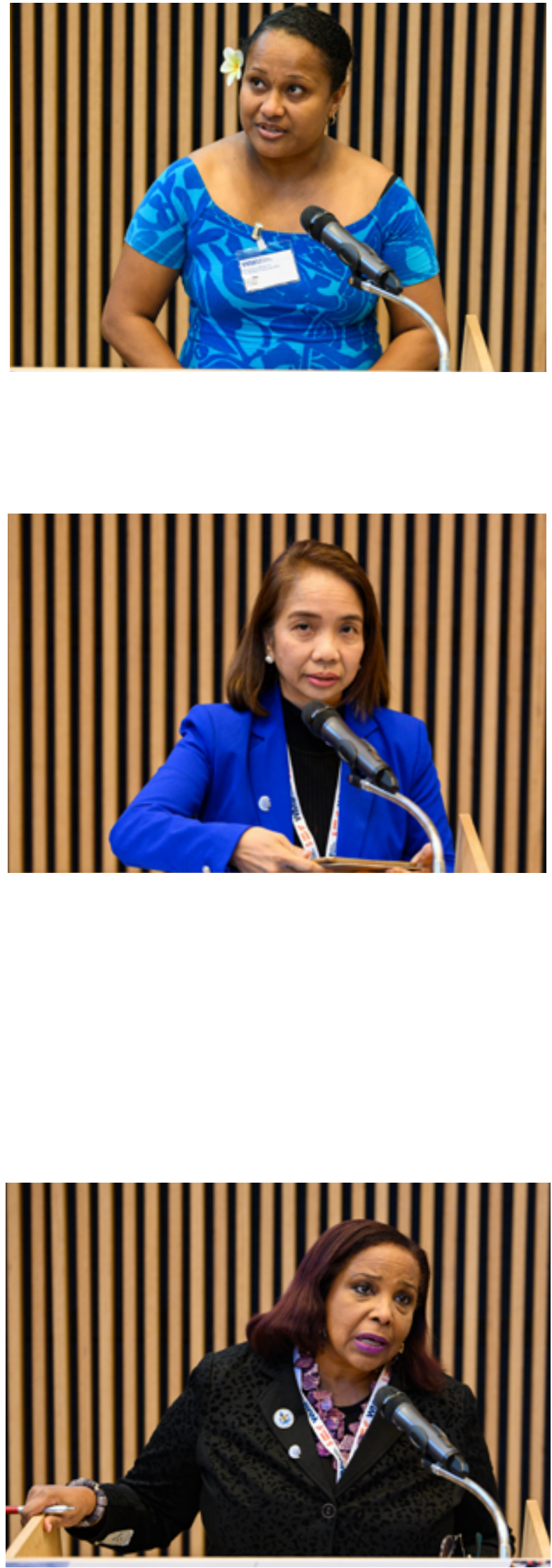

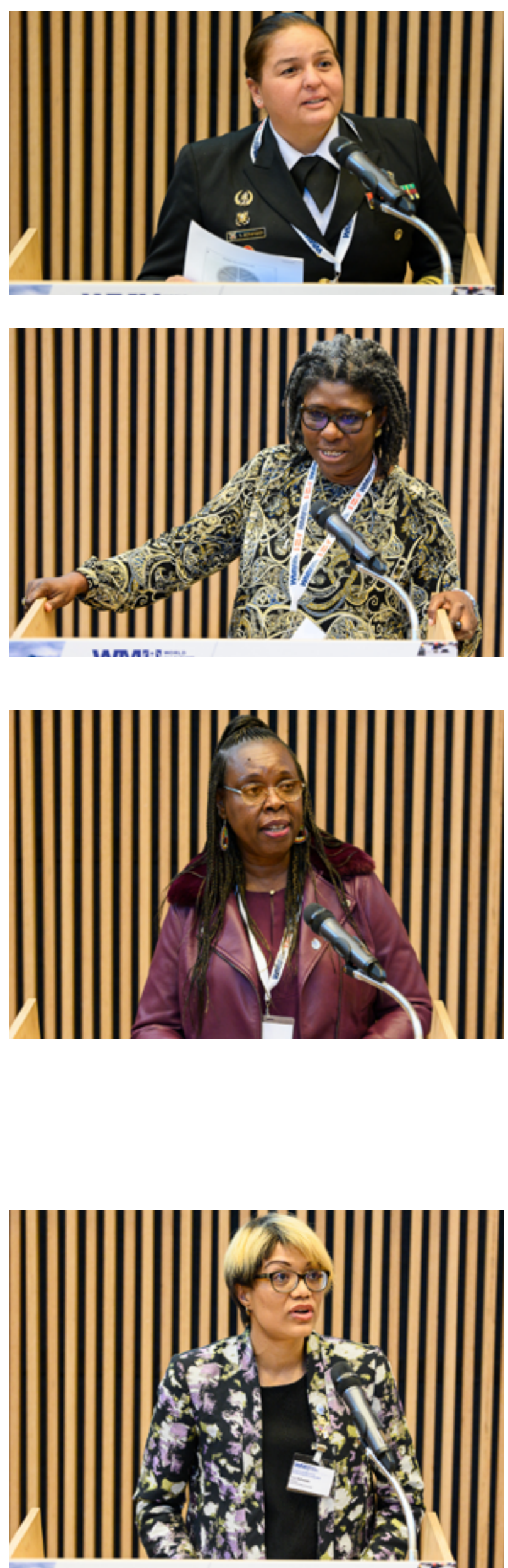

Red de Mujeres de Autoridades Marítimas de Latinoamérica (Red-MAMLa) was established in Chile in December 2017.

The Red-MAMLa network was represented by Ms. Nora Marcela Benavides Luna who is a 2016 WMU graduate. Red-MAMLa was established primarily to be a regional cooperation network for women who belong to the military forces in Latin America. Through training, visibility, and recognition, Red-MAMLa will increase the profile of women military officers in Latin America.

The Network of Professional Women in the Maritime and Port Sectors for West and Central Africa was launched in Benin in February 2007, and is set for a relaunch in 2019.

The IMO has been working with its West and Central African partners and aims to relaunch the Network of Professional Women in the Maritime and Port Sectors for West and Central Africa in 2019. Ms. Florentine GuihardKoidio represented the region. Key issues are education and awareness-raising. Ten women in managerial positions, including 3 active members have currently joined the association. They are organizing a capacity-building workshop for women in the port and maritime sectors in Cape Verde soon after this Conference.

African Women in Maritime Association (WIMAFRICA) was established in 2015, but does not fall under the auspices of the IMO.

WIMAFRICA is a non-IMO-affiliated WIMA. However, WIMAFRICA also supports the IMO initiative of achieving gender equality. Ms. Jean Chiazor-Anishere, Head of WIMAFRICA, introduced her association, established in 2015 with 10 African member countries, six of which participated in the WMU Conference. Their main activity is to sustain the blue economy for African oceans and seas, for example, with plastic recycling to generate income and protect the oceans. WIMAFRICA won an African Union Blue Economy Award at the Blue Economy Conference in Kenya in 2018. Marine engineers at the Nigerian Port Authority support WIMAFRICA. The first African officer on Celebrity Cruises, Ms. Nicholine Tifuh Azirh, is a member from Cameroon. Women in fishing and aquaculture are also supported in Angola, Nigeria, Rwanda and Togo through WIMAFRICA.

WMU Women's Association (WMUWA) was established in Sweden in April 2014. (https://www.facebook.com/ WMU-Womens-Association-1433150183591649/)

WMUWA was established by the WMU female students as one of the outcomes from the previous WMU women's conference on Maritime Women: Global Leadership, 2014. Since its establishment, WMUWA has regularly submitted information papers to the IMO Technical Cooperation Committee. Their activities include the International Women's Day event, a public speaking workshop, a gender seminar called 'maritime soiree' and other community support activities. WMUWA has associated members, including men and non-WMU graduates who support gender equality in the maritime sector. 


\section{LAUNCH OF RESEARCH PROJECT}

entitled 'Empowering Women for the United Nations Decade of Ocean Science for Sustainable Development', funded by the Department of Fisheries and Oceans Canada.

\section{Dr. Geneviève Béchard}

Hydrographer General of Canada and Director General for the Canadian Hydrographic Service with Fisheries and Oceans Canada

During the Conference, a new Gender and Ocean Research Project sponsored by the Government of Canada was launched.

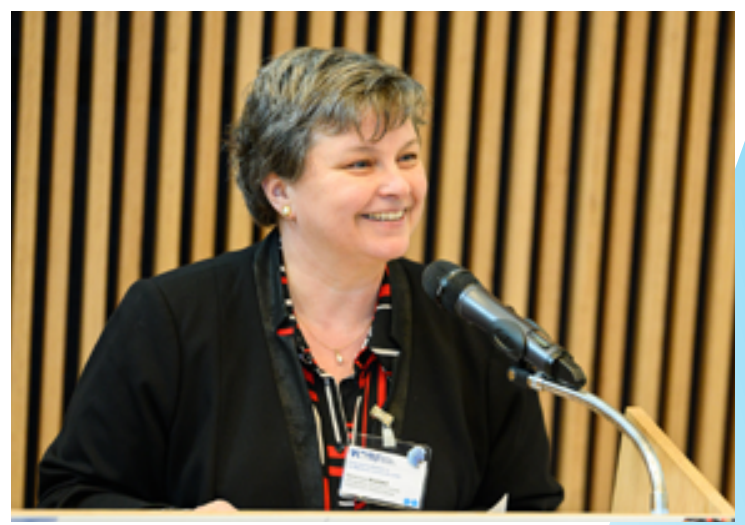

Dr. Genevieve Béchard, Hydrographer General of Canada, on behalf of the Government of Canada and WMU President, Dr. Cleopatra Doumbia-Henry, issued a joint announcement regarding the signed Grant Agreement to launch the research project. The Canadian Department of Fisheries and Oceans (DFO) has provided generous support for the implementation of a research project, entitled "Empowering Women for the United Nations Decade of Ocean Science for Sustainable Development", which will be conducted by the WMU.

In the framework of the research project, a Ph.D. Scholarship and Post-Doctoral Fellowship Programme will be sponsored to address gender empowerment in support of the Decade of Ocean Science for Sustainable Development through research, education and capacity-building. The programme aims to develop pathways to promote gender equality and the empowerment of women in the conduct of ocean science, and gender equality in the regulatory and ocean science governance systems that coordinate, manage and mediate ocean science. This research is motivated by the fact that ocean science-related fields and regulatory and ocean governance systems play a crucial role in advancing specific targets under the 2030 Agenda, coupled with recognition that these objectives cannot be realised without the full engagement of women.

The objective is to propose a strategy and action plan to help deliver equal opportunities for full participation and leadership by women at all levels of ocean science and science dependent governance systems. The project will be implemented during a three-year period and will commence in 2019. It will evolve around two strands: 1 . The role of gender equality and empowerment of women in the conduct of ocean science; and 2. Gender equality in the regulatory and ocean science governance systems that coordinate, manage and mediate ocean science. A High-Level Advisory Group will be established under the project and also an Ocean Science and Ocean Science Governance Stakeholder Forum. In order to align the research efforts with ongoing processes, the plan is that the researchers participate in intergovernmental processes at the international, regional and national levels and also consult with key stakeholders. 

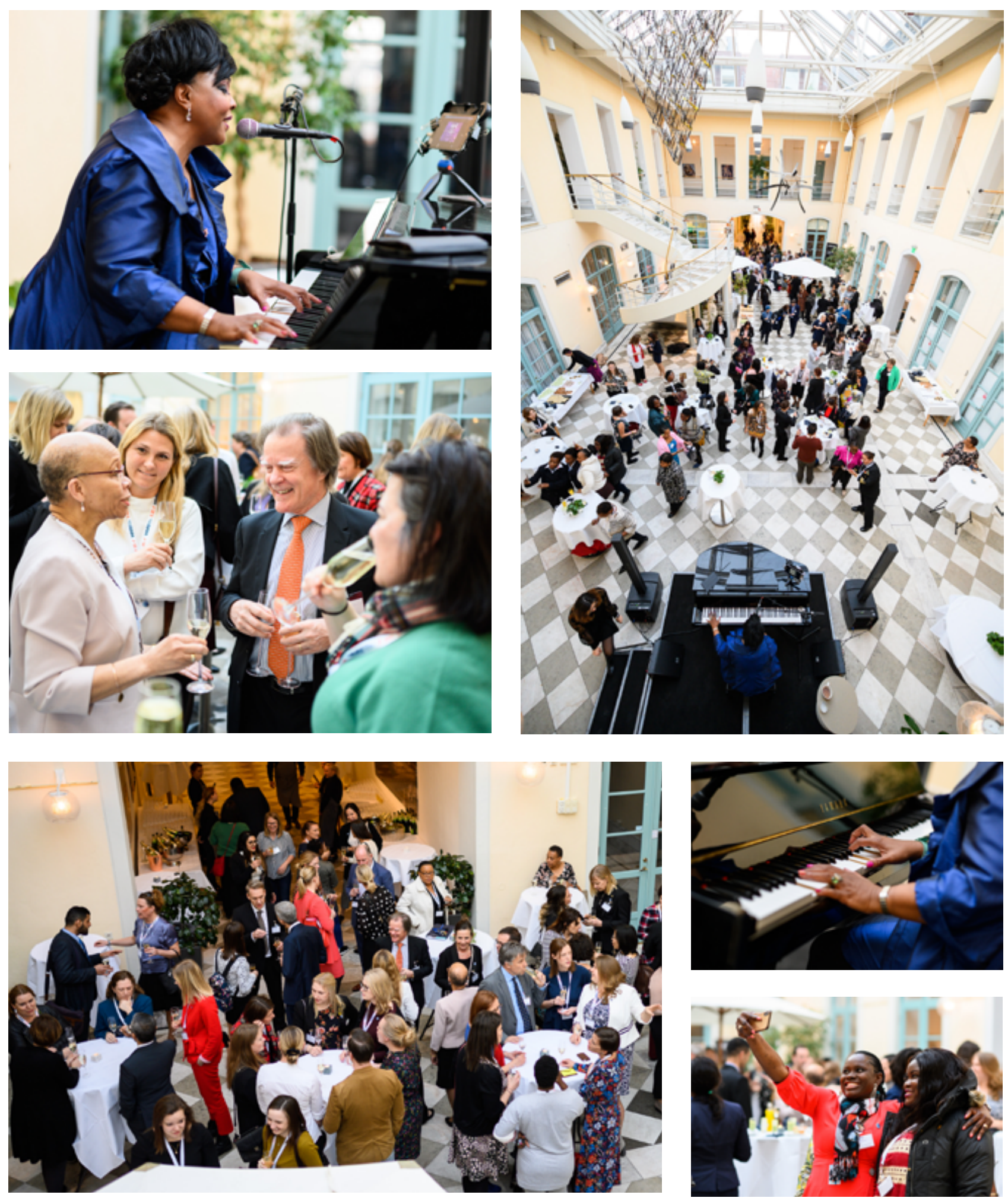

\section{COCKTAIL RECEPTION}

Mrs. Karen Edwards gave a special live performance for the WMU women's conference during the cocktail reception. Mrs. Edwards is known as an unusual pianist and vocalist, and was many times nominee for the "Grammy Award for Jazz Performance". She has worked successfully with many internationally known artists, including Stevie Wonder, Peabo Bryson, Tony Bennett and Pharoah Sanders. She also recently collaborated with the famous musician, Prince. 


\section{CLOSING SESSION AND CONCLUSIONS}

MODERATED BY MS. NANCY WAKARIMA KARIGITHU, PRINCIPAL SECRETARY, MINISTRY OF TRANSPORT, INFRASTRUCTURE, HOUSING \& URBAN DEVELOPMENT AND PUBLIC WORKS, KENYA

With over 70 high-level speakers and around 350 participants from more than 70 countries, the WMU Third International Women's Conference served as an exceptional platform for discussion, as concluded by the President of the WMU, Dr. Cleopatra Doumbia-Henry. Over two days, facts, experiences, policies and strategies were shared with the common goal of shedding light on the high impact that women's activities already have in all maritime industries and academia.

However, in an attempt to enhance a far from perfect situation, the Conference closed by adopting a set of conclusions as a way forward and a contribution to achieving SDG 5 on Gender Equality. These conclusions are a distillation of the two-day brainstorming process and seek to push organizations, governmental entities and stakeholders in the maritime and ocean communities to take action and adopt concrete and measurable gender-responsive policies and programmes.

Shipping, ports, fishing, seafood harvesting, marine and energy research and other sea-related activities, are all sectors that were represented in the Conference accounting for the richness of the conclusions, that also served as a reminder of the special needs and role of indigenous communities. All in all, instilling inclusiveness in the maritime and ocean communities has to go hand-in-hand with making them sustainable and preserving the oceans for the generations to come. 


\section{CONCLUSIONS OF THE THIRD WMU INTERNATIONAL WOMEN'S CONFERENCE ON "EMPOWERING WOMEN IN THE MARITIME COMMUNITY" (EWMC 2019)}

The Third International Women's Conference organized by the World Maritime University (WMU) in Malmö, Sweden, met from 4 to 5 April 2019, on the theme "Empowering Women in the Maritime Community." The Conference:

Recalled that the United Nations (UN) Sustainable Development Goals (SDGs) of the 2030 Agenda for Sustainable Development were adopted by more than 150 world leaders during the UN Sustainable Development Summit from September 25-27 at UN headquarters in New York, and in September 2015 at a historic UN Summit;

Welcomed the decision by the International Maritime Organization (IMO) that "Empowering Women in the Maritime Community" would be the theme for World Maritime Day 2019, in line with the SDGs, in particular Goal 5 on achieving gender equality and empowering all women and girls:

Acknowledged IMO's efforts in achieving SDG Goal 5 as indicated in Resolutions adopted by the IMO on the "Promotion of the participation of women in the maritime industry" adopted in 1998 and 2010; the "Busan Declaration" adopted during the IMO Regional Conference on the Development of a Global Strategy for Women Seafarers in 2013; and the capacity-building programme, previously known as the Integration of Women in the Maritime Sector (IWMS);

Took into account the steps taken by the International Labour Organization (ILO) to ensure the equal opportunity principle and prohibit gender discrimination, as required in the Equal Remuneration Convention, 1951 (No. 100); and the Discrimination (Employment and Occupation) Convention, 1958 (No. 111);

Recommended that all Member states ratify and implement the ILO Maritime Labour Convention, 2006, with a view to achieving the 100 ratification target by end of 2019 in celebration of ILO's 100th anniversary, as well as the Work in Fishing Convention, 2007 (No. 188);

Welcomed the efforts to promote the effective implementation of an inclusive work environment on board ships, as well as initiatives such as the ILO Sectoral Meeting on the Recruitment and Retention of Seafarers and the Promotion of Opportunities for Women Seafarers, held in Geneva, Switzerland, from 25 February to 1 March 2019;

Built upon previous initiatives taken by WMU to host a First International Conference on the Empowerment of Professional Women in the Maritime World in 2008, and a second International Conference on Maritime Women: Global Leadership in 2014; and

Appreciated warmly the generosity of all donors to and sponsors of the Third WMU International Conference on Empowering Women in the Maritime Community.

The Participants of the Conference committed in their respective sectors and areas of responsibility to cooperate, coordinate and collaborate in the development and implementation of genderresponsive policies, measures and related programmes. 
The Participants urged international organizations, governmental entities and stakeholders in the maritime and ocean communities, including those in shipping, ports, fishing, seafood harvesting, marine and energy research and other sea-related activities to:

- develop, adopt and enforce gender-responsive policies and related programmes while ensuring that the policy development process is consultative, participatory and includes all relevant international organizations, governmental entities, industry and other non-governmental stakeholders;

- improve the visibility of women professionals in all searelated sectors by mapping out the number and positions they occupy and take measurable actions that can contribute to progress;

- $\quad$ promote role models for women in the maritime and ocean communities that can inspire and attract younger generations to sea-related activities, empowering women to acquire skills necessary to achieve leadership positions and break the glass ceiling;

- motivate women and girls in primary and secondary education to pursue career paths in the maritime and ocean fields, and in particular to raise their awareness in the fields of science,technology and IT-related competencies, engineering and mathematics;

- $\quad$ open early-career job opportunities for women and develop attractive career paths for them;

- $\quad$ organize mentoring, sponsorship and networking programmes that increase recruitment and retention of women in the maritime and ocean communities;

- $\quad$ mainstream gender in the maritime and ocean professions to enhance respect for diversity and achieve a work environment free from violence, discrimination and harassment;

- $\quad$ give priority to funding gender research on maritime and ocean fields, particularly in occupational health and safety matters;

- $\quad$ raise awareness of the significant economic contribution of women in all sea-related activities, including the special needs and role of indigenous communities;

- $\quad$ provide gender-sensitive working and living conditions on board ships;

- implement conciliation measures to make work time compatible with private and family life for all workers regardless of gender;

- ensure equal employment opportunities, including equal pay for women in the maritime and ocean communities.

- $\quad$ introduce gender equality as a business case for initiating commercial partnerships;

- develop and implement corporate policies and best practices on the employment of women;

- implement a plan to enhance diversity and equality at all levels;

- $\quad$ ensure a consultative approach in global development taking into account those communities that are dependent on the oceans for their survival; and

- $\quad$ include women in all decision-making relating to policies and regulations. 


\section{WMU STAFF GROUP BY GENDER}

AS OF 31 DECEMBER 2018

\section{눈}

\section{Professional}

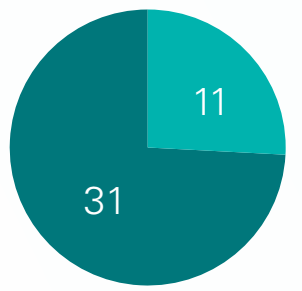

$26 \%$

FEMALE

\section{General Service}

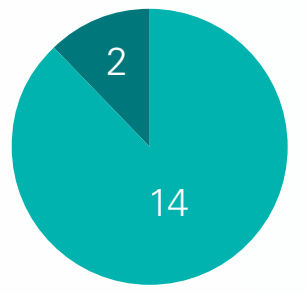

$88 \%$

FEMALE

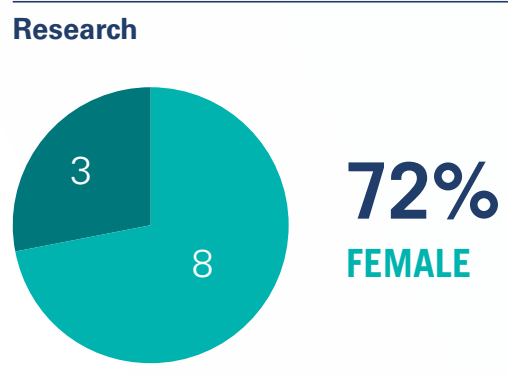

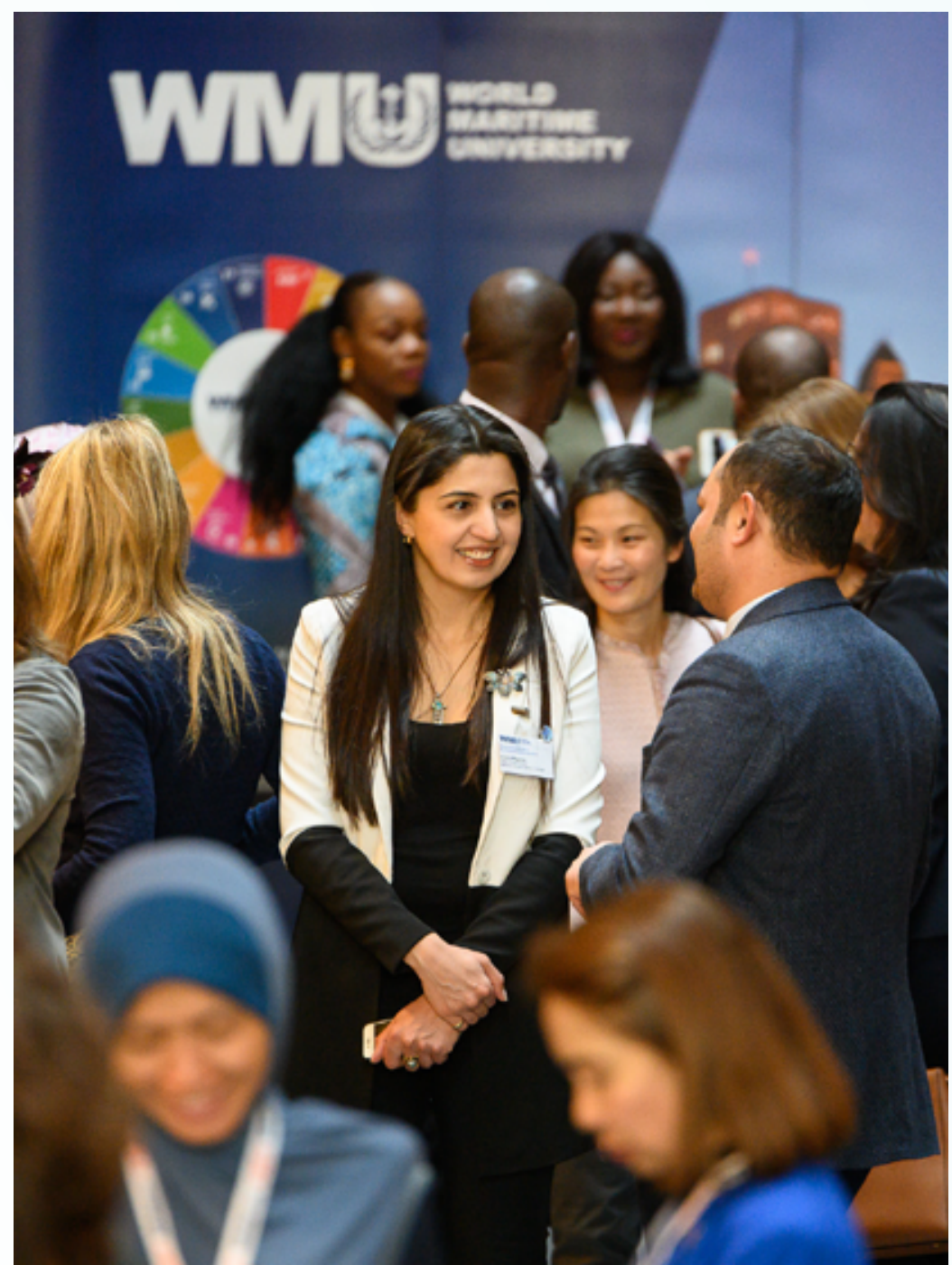

\section{WMU ENROLMENT BY GENDER}

Enrolment by gender in Malmö 1983-2018

인 인

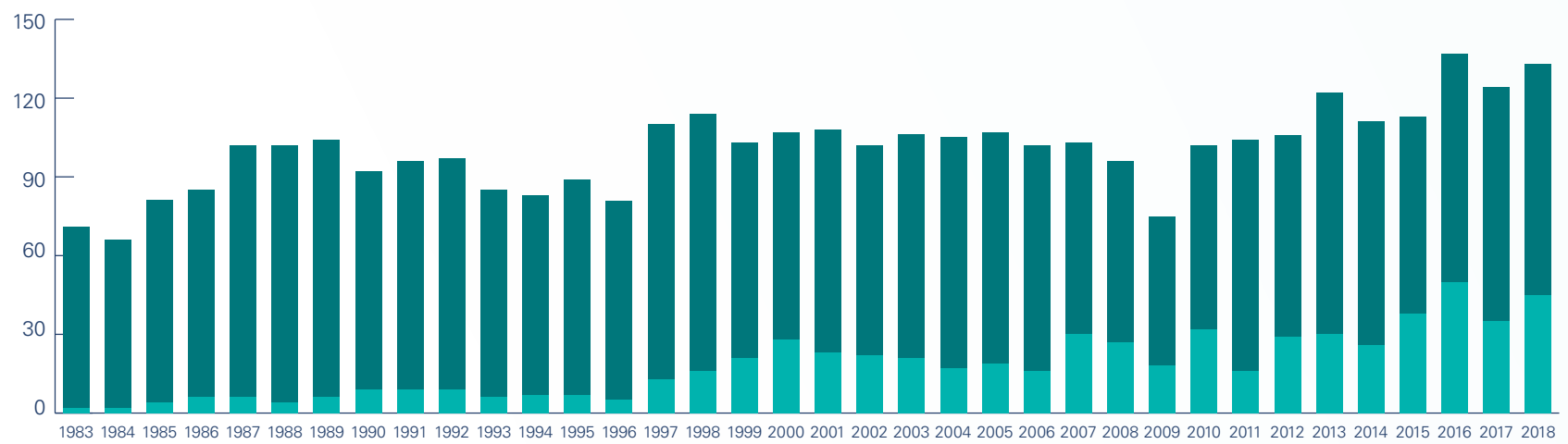




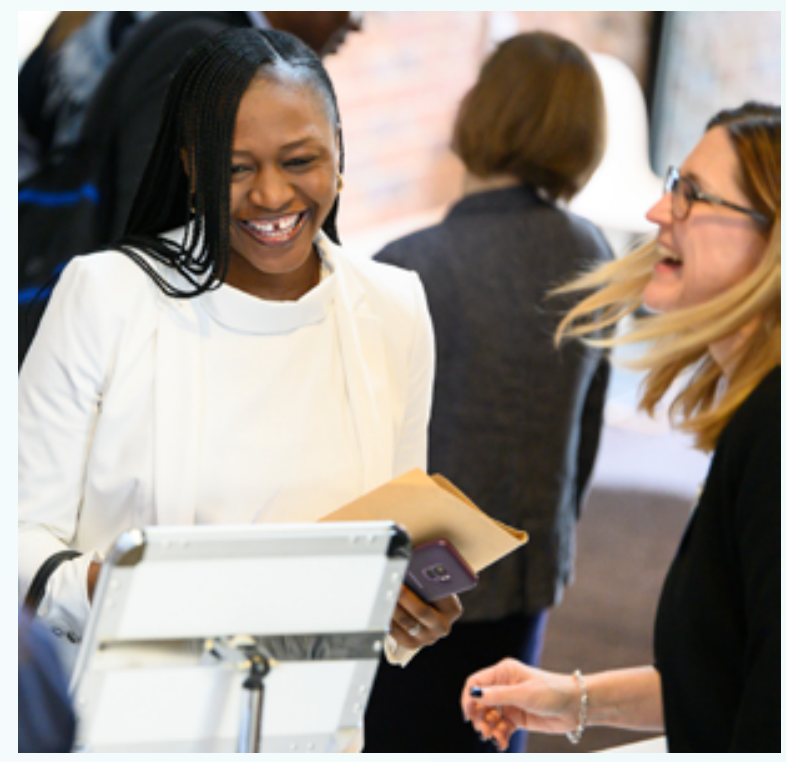

\section{ENROLMENT BY GENDER}

$\prod_{11}^{\circ}$
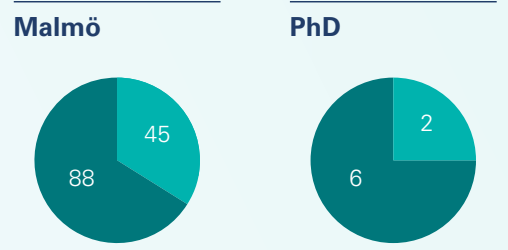

Dalian MSEM

Shanghai ITL
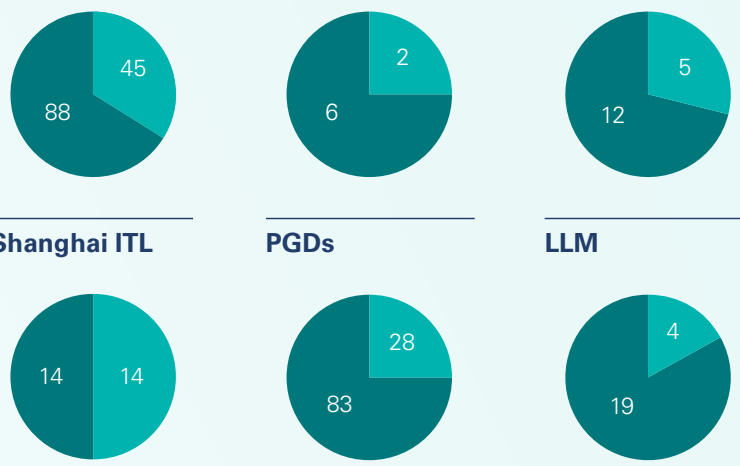

LLM

\section{GRADUATES BY GENDER}

\section{1}
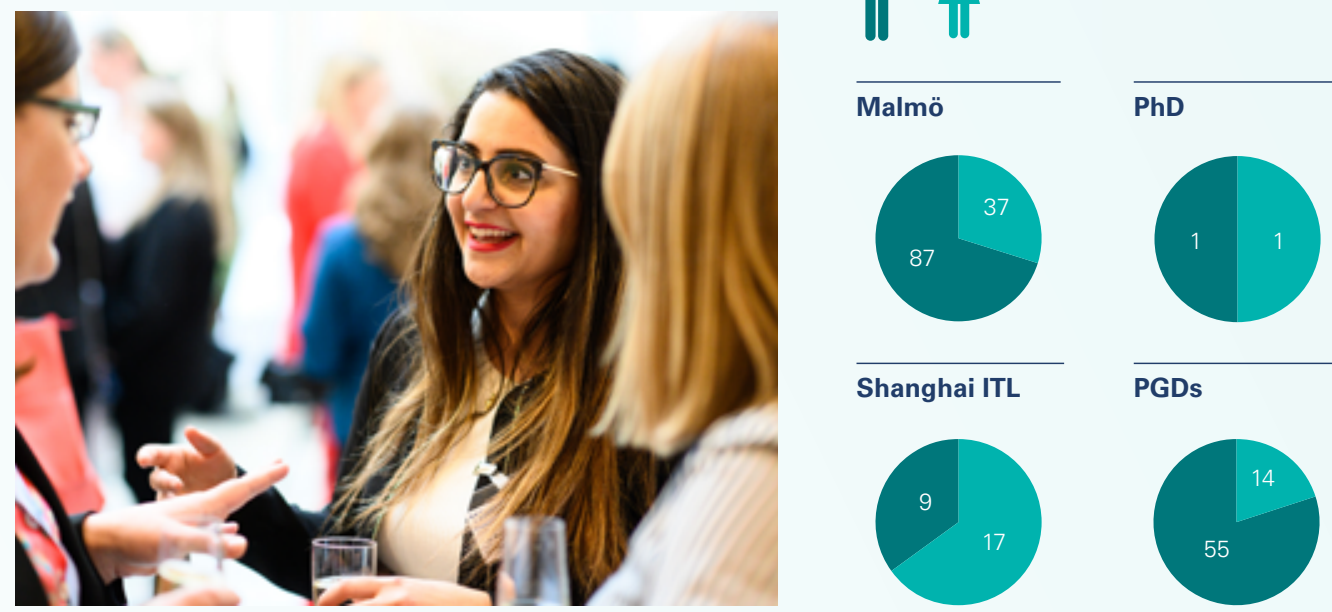

Dalian MSEM

Shanghai ITL

PGDs
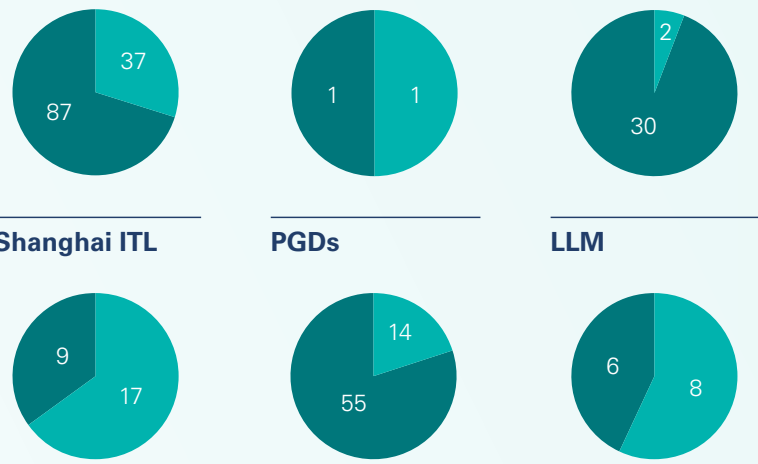

LLM
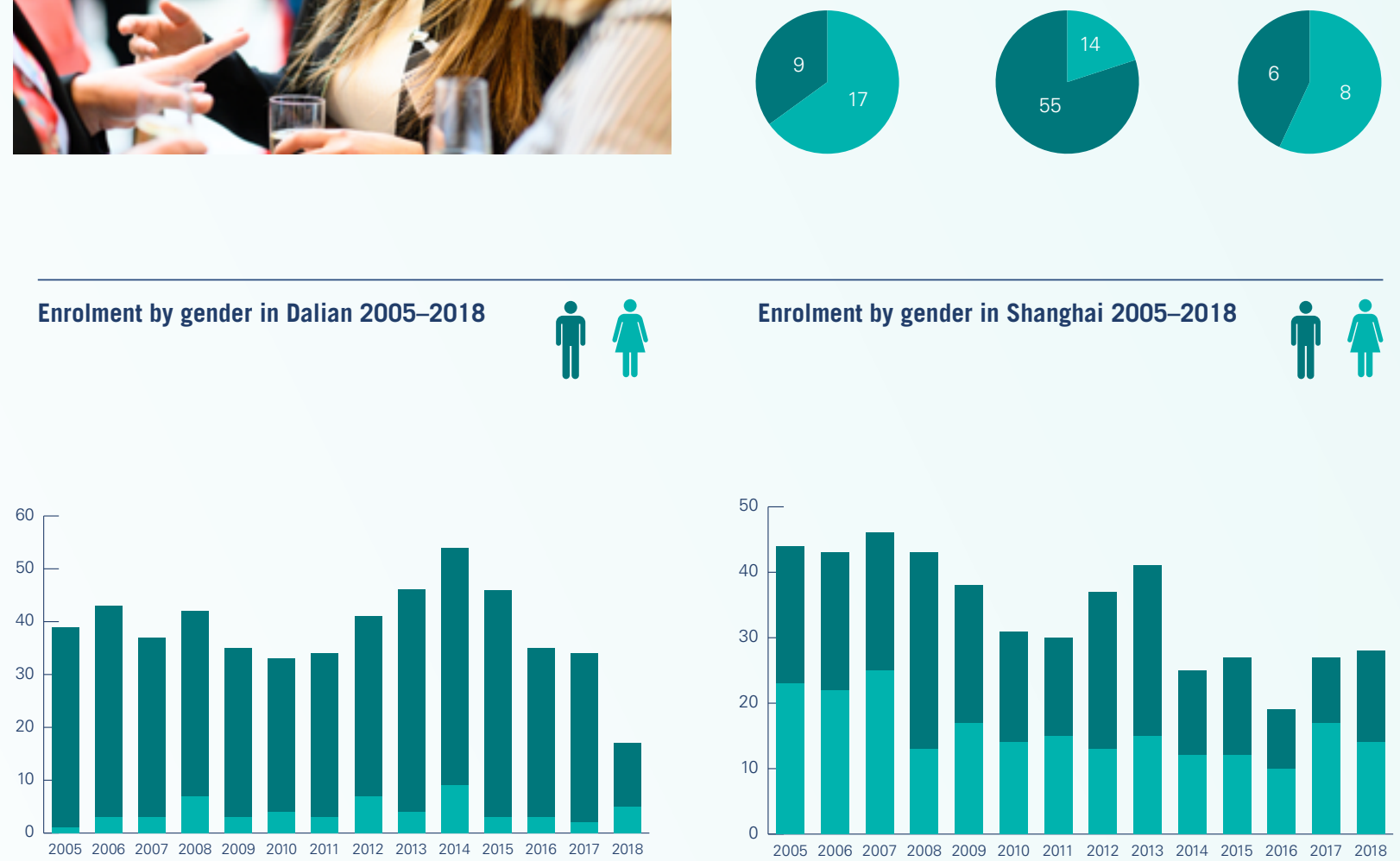


\section{ACKNOWLEDGMENTS}

The WMU hereby extends its sincere gratitude to all the Conference sponsors: the International Maritime Organization, the Nippon Foundation, the International Transport Workers' Federation Seafarers' Trust, Celebrity Cruises, Fisheries and Oceans Canada, the Maritime and Coastguard Agency of the United Kingdom, Stena Line and Stena Bulk.
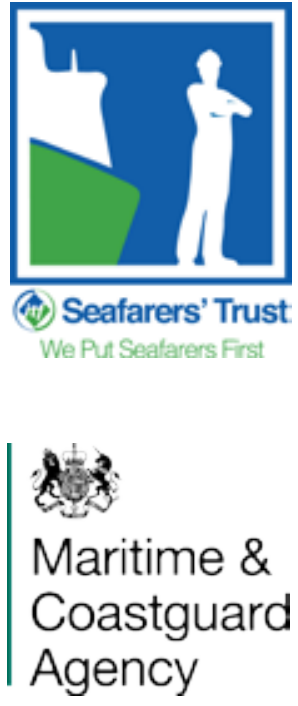
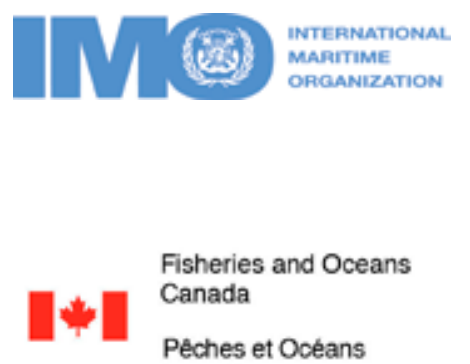
Canada

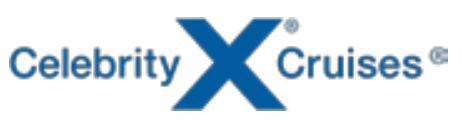

\section{S}

StenaLine

S

\section{Organizing Committee}

Aleke Stöfen-O'Brien, Benjamin Zhu, Clive Schofield, Johan Hollander, Joseph Harbouk, Katharina Serrano, Laura Carballo Piñeiro, Maia Brindley Nilsson, Maximo Q. Mejia Jr., Momoko Kitada, Monica Canepa, Raphaël Baumler, Ronán Long, Satya Sahoo, Tafsir Johannson, and Zhen Sun, support from Ammar Jaber, Anne Pazaver, Cleto del Rosario, Christopher Hoebeke, Damilola Idris Osinuga, Daniella Charzuk, Elnaz Barjandi, Erik Ponnert, Jens-Uwe Schröder-Hinrichs, Jill Jarnsäter, Jenette Tifuh Mujingni, Khanssa Lagdami, Linda Wiltshire, Murray Rudd, Neil Bellefontaine, Osatohanmwen Anastasia Eruaga, Rebecca Mejia, Seyedvahid Vakili, Tiago Fonseca, WMU Women's Association, and WMU World Bistro. 

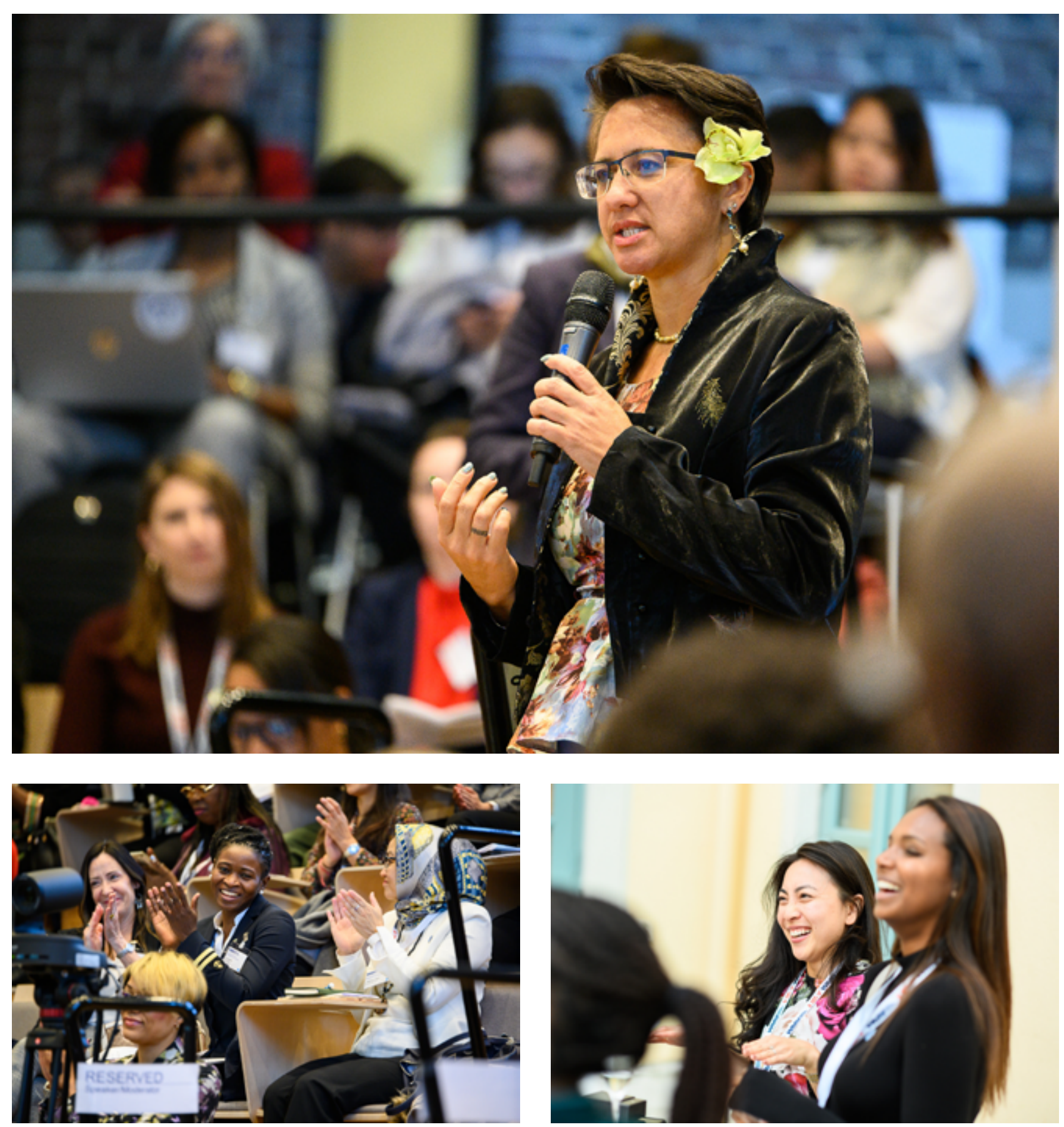


\section{WMU}

World Maritime University

PO Box 500

S-201 24 Malmö

Sweden

www.wmu.se

The World Maritime University was established in 1983 within the framework of the International Maritime Organization, a specialized agency of the United Nations. 